\title{
Building a DNA barcode library of Alaska's non-marine arthropods
}

\begin{tabular}{|r|l|}
\hline Journal: & Genome \\
\hline Manuscript ID & gen-2015-0203.R4 \\
\hline Danuscript Type: & Article \\
\hline Complete List of Authors: & $\begin{array}{l}\text { Sikes, Derek; University of Alaska Museum } \\
\text { Bowser, Matthew; Kenai National Wildlife Refuge } \\
\text { Morton, John; Kenai National Wildlife Refuge } \\
\text { Bickford, Casey; University of Alaska Museum } \\
\text { Meierotto, Sarah; University of Alaska Museum; University of Kentucky } \\
\text { Hildebrandt, Kyndall; University of Alaska Museum }\end{array}$ \\
\hline Keyword: & DNA barcoding, inventory, monitoring, Arthropoda, biodiversity \\
\hline & \multicolumn{2}{|l}{} \\
\hline
\end{tabular}

SCHOLARONE $^{\text {Im }}$

Manuscripts 


\section{Building a DNA barcode library of Alaska's non-marine arthropods}

Derek S. Sikes ${ }^{1}$, Matthew Bowser ${ }^{2}$, John M. Morton ${ }^{2}$, Casey Bickford ${ }^{1}$, Sarah

Meierotto $^{1,3}$, Kyndall Hildebrandt ${ }^{1}$

1 University of Alaska Museum, Fairbanks, Alaska, 99775-6960, USA

2 U.S. Fish and Wildlife Service, Kenai National Wildlife Refuge, PO Box 2139,

Soldotna, Alaska, 99669, USA

3 University of Kentucky, S-225 Ag. Sci. N, Lexington, KY 40546-0091, USA

Corresponding author

Dr. Derek S Sikes

University of Alaska Fairbanks

Biology \& Wildlife

University of Alaska Museum

907 Yukon Dr

Fairbanks

Alaska

99775

United States

Phone: 907-474-6278

E-Mail Address: dssikes@alaska.edu 
Abstract: Climate change may result in ecological futures with novel species assemblages, trophic mismatch, and mass extinction. Alaska has a limited taxonomic workforce to address these changes. We are building a DNA barcode library to facilitate a metabarcoding approach to monitoring non-marine arthropods. Working with the Canadian Centre for DNA Barcoding, we obtained DNA barcodes from recently collected and authoritatively identified specimens in the University of Alaska Museum Insect Collection and the Kenai National Wildlife Refuge collection. We submitted tissues from 4,776 specimens, of which $81 \%$ yielded DNA barcodes representing 1,662 species and 1,788 Barcode Index Numbers (BINs), of primarily terrestrial, large-bodied arthropods. This represents $84 \%$ of the species available for DNA barcoding in the UAM Insect Collection. There are now 4,020 Alaskan arthropod species represented by DNA barcodes, after including all records in BOLD of species that occur in Alaska - i.e. $48.5 \%$ of the 8,277 Alaskan, non-marine-arthropod, named species have associated DNA barcodes. An assessment of the identification power of the library in its current state yielded fewer species-level identifications than expected, but the results were not discouraging. We believe we are the first to deliberately begin development of a DNA barcode library of the entire arthropod fauna for a North American state or province. Although far from complete, this library will become increasingly valuable as more species are added and costs to obtain DNA sequences fall.

Key words: DNA barcoding, inventory, monitoring, Arthropoda, biodiversity 


\section{Introduction}

Alarming ecological and physical changes are being seen in Alaska (Chapin et al. 2006). North America's northernmost latitudes are warming more rapidly than any other region on Earth (Serreze et al. 2000). Alaska has warmed $\sim 2{ }^{\circ} \mathrm{C}$ since the 1950 s and 3.5 ${ }^{\circ} \mathrm{C}$ during the winter in interior Alaska (US Global Change Research Program, National Assessment, 2001). Shrubs are expanding into tundra and alpine zones, the growing season has lengthened by about two weeks, fires are more intense and frequent, glaciers and permafrost are melting, and Alaska's climate is shifting beyond the physiological optimum for one of its dominant boreal forest species, the white spruce Picea glauca (Veblen and Alaback 1996, Stone et al. 2002, Lawrence \& Slater 2005, Sturm et al. 2005, McGuire et al. 2009, Beck et al. 2011, Juday et al. 2015).

Alaska is also a unique biogeographic zone due to its mostly glacier-free Neogene and Pleistocene history (Ives 1974, Matthews 1975, Behan 1978, Pielou 1991), which, unlike much of Canada, allowed organisms to survive in ice-free refugia (e.g., Beringia). This likely explains the hundreds of potentially endemic, mostly flightless, arthropod species in Alaska (Sikes \& Allen 2016). Additionally, Alaska's former connection to Asia via the Bering Land Bridge has resulted in many complex and interesting biogeographic patterns between the Nearctic and Palearctic. Documentation of genetic diversity in Alaska, which is expected to contain unique mitochondrial lineages as a result of its mostly glacier-free past, will help build a Holarctic reference library that could be used to better understand this complex biogeographic history. 
Establishment of a well-documented baseline for this unique biodiversity of Alaska, prior to predicted radical changes due to climate change, is an urgent priority. This baseline will allow future monitoring to detect range shifts, extirpations, extinctions, invasions, and novel species assemblages. It will also provide a starting point for phylogeographic studies.

However, Alaska has a limited taxonomic workforce with neither the expertise nor resources to identify all taxa for the purposes of inventory and monitoring. In this context, DNA barcoding generally improves the identification reliability for species that can only be identified by one sex or life stage, and enables identification of damaged specimens, and can therefore help detect range shifts that might otherwise go undetected (e.g. Chown et al. 2009, Hendrich et al. 2010, Slowik and Blagoev 2012). It can also be employed for the identification of taxa which lack sufficient taxonomists to meet identification requests. DNA barcodes can offer insights into genetic diversity of taxa lacking a solid taxonomic framework; e.g. those with cryptic biodiversity (Bálint et al. 2011). Additionally, newer methods that sequence the barcode gene region from multiple species simultaneously using next-generation sequencing (aka metabarcoding) offer the potential to measure community compositions, such as from aquatic or vertebrate gut samples, and species assemblages at very low cost (Pons 2006, Valentini et al. 2009, Ji et al. 2013).

Canada, Finland, Germany, and Norway are building DNA barcode libraries of their biotas (Gwiazdowski et al. 2015, Geiger et al. in press). The Zoologische Staatssammlung München in Germany is assembling a barcode library for Bavaria 
(http://www.faunabavarica.de/) using an incremental taxon-specific approach (e.g. Myriapoda [Spelda et al. 2011], butterflies \& macromoths [Hausmann et al. 2011], Geometridae [Hausmann et al. 2011], Neuroptera, [Gruppe et al. 2014], Heteroptera [Raupach et al. 2014]), but no North American state or province has attempted to build a comprehensive DNA barcode library of their arthropod fauna.

The University of Alaska Museum (UAM) Insect Collection and Kenai National Wildlife Refuge (KNWR) have been collaborating in non-marine arthropod identification for several years, including development of a draft species checklist for Alaska. The UAM Insect Collection, established in 2000, has become a world-class data and specimen depository for Alaska's biodiversity. Over $80 \%$ of the $1.2 \mathrm{M}$ non-marine arthropod specimens catalogued into UAM as 234,745 georeferenced, online database records (as of 10 November 2015) were collected since the year 2000, making this collection ideal for genetic sampling from conventionally prepared entomology museum specimens. The KNWR has completed a spatially-explicit inventory of almost 400 arthropod species over 805,000 ha (Bowser and Morton 2009, Morton et al. 2009), in addition to conducting or cooperating on other surveys for the purpose of increasing its inventory of arthropod species richness.

The aim of our project was to obtain DNA barcodes for as many Alaskan nonmarine arthropod species as possible for the explicit purpose of building a genetic reference library for researchers and others engaged in using DNA sequences as an identification tool. Further objectives were to assess the usefulness of the DNA barcode 
library by using it to identify unidentified specimens and evaluating its potential ability to discriminate among named species.

\section{Materials and methods}

Sampling of specimens. Building a DNA barcode library in the most cost-effective manner, as measured by cost per species, is best achieved by use of previously identified specimens to avoid an over-abundance of common species in the library. Specimens in UAM used for this project were not collected expressly for this project, but were collected for other projects and archived dry or in $70 \%$ ethanol at room temperature. Although DNA barcodes have been successfully obtained from relatively old Alaskan specimens (e.g. 68 years old, BOLD ID = ZYPAN420-10), among the specimens selected from UAM or the KNWR collections, only 31 were older than ten years. The oldest of these was collected in 1981. The remaining specimens were collected in 2002 or more recently, with the majority collected between 2009 and 2012 (Fig. 1); i.e., less than 5 years old at the time of DNA extraction. This date range can be explained by the fact that DNA sequencing success declines with specimen age (Hebert et al. 2013), while the probability of a specimen being identified to species increases with age due to greater time being available for specialists to request and return loans. Thus, when building such a DNA barcode library one cannot use entirely one year old or younger specimens because although their DNA would be of high quality, they would likely not yet be identified. We selected the youngest specimens possible with a preference for handcollected specimens over trapped specimens because the latter are usually exposed to 
DNA-degrading conditions for longer periods than the former. When multiple specimens were available for a species we selected specimens from different geographic regions within Alaska, if possible. Although the majority of specimens were collected near populated centers and along the road system of Alaska (Fig. 2), all major regions of Alaska (Arctic, Aleutians, southcentral, interior, and southeast Alaska) were represented. Specimens were collected using a wide variety of methods (hand, Berlese funnel, sweep net, beating, passive trapping: e.g., pitfall, Malaise, flight intercept, Lindgren) and killed and preserved in either ethanol (70-90\%, rarely 100\%) or propylene glycol. This variety of methods included some that were ideal for DNA preservation (e.g., specimens placed alive into $100 \%$ ethanol, frozen immediately, and kept frozen until DNA barcoding) to those that were quite suboptimal (e.g., specimens caught in a passive pitfall trap, left in the field for 2 weeks in rain-diluted propylene glycol, and then stored in the same propylene glycol at room temperature for months before being processed).

Generally, samples were kept frozen at $-20{ }^{\circ} \mathrm{C}$ after arrival in the lab prior to processing onto pins or into vials of $70 \%$ ethanol. Once processed, specimens were stored at room temperature. Two specimens per species were selected for DNA barcoding except when only one specimen was available for a species, in which case that specimen was used for DNA barcoding. Rarely, three or more specimens were used when there was a broad geographic spread of specimens available or when there was apparent morphological variation that might indicate large among-population genetic diversity or cryptic species. Identifications were performed by over 150 entomologists / arachnologists (listed in the Acknowledgements) using appropriate taxonomic literature. 
Most KNWR specimens used for DNA barcoding came from KNWR's Long Term Ecological Monitoring Program (LTEMP) (Morton et al. 2009) and a 2011 Rapid Ecological Assessment with the express purpose of obtaining specimens for DNA barcoding (REA) (Bowser 2012).

For the LTEMP, we sampled arthropod occurrence and relative abundance within 255 5.64-m radius circular plots systematically spaced at $5 \mathrm{~km}$ intervals over the 805,000 ha KNWR using a 30-cm (12 inch) diameter sweep net (BioQuip ${ }^{\text {TM }}$ model 7112CP with $30 \mathrm{~cm}$ extension handle). All specimens were placed in a single Nalgene ${ }^{\circledR}$ wide-mouth $250 \mathrm{ml}$ bottle containing sufficient $95 \%$ denatured ethanol to cover the sample. Species were identified in-house whenever possible, but many specimens were shipped to $>40$ specialists for expert determinations (listed in Acknowledgments).

For the REA, we employed a wide variety of DNA-friendly collecting methods (sweep nets, aerial nets, Malaise traps, pan traps, sieves, aquatic nets, streamside washing of substrate, and searching under stones, logs, and under bark by hand) from June 27 to July 1, 2011 at three sites on KNWR representing boreal forest, glacial outwash plain, and subalpine habitats. At these sites we attempted to sample all available microhabitat types (streams, lakes, ponds, terrestrial vegetation, gravel bars, etc.). Passive traps (Malaise and pan traps) were run for approximately 24 hours. Most specimens were placed in $90-100 \%$ ethanol or immediately frozen in coolers with dry ice. Specimens collected into ethanol were transferred to a freezer upon returning to the lab. 
DNA sequencing and data depository. Specimens were processed in groups of 95, reflecting the 95 wells in a 96-well microplate with one well left empty as a negative control, as described and illustrated in Hebert et al. (2013) with the exception that a single laboratory technician managed the workflow alone rather than in a team (each of the authors, except JM, prepared plates). Each 96-well plate, with one specimen leg per well, was sent to the Canadian Centre for DNA Barcoding (CCDB), University of Guelph. Each de-legged specimen was photographed using a Leica DFC425 camera mounted on a Leica MZ16 stereomicroscope in combination with Leica Application Suite (C) software v.3.8.0. Photographs were reduced in size and brightened using Adobe Photoshop v.CS6 to conform to expectations for posting in the Barcode of Life Data System (BOLD; Ratnasingham and Hebert 2007). Data files and images were uploaded to the BOLD website. The CCDB followed standardized high-throughput protocols for DNA extraction, amplification, and bidirectional sequencing (Ivanova et al. 2006, deWaard et al. 2008, http://ccdb.ca/resources.php). We opted to include 'failure-tracking' for this project which attempts to recover DNA barcodes from specimens that failed in the first pass, using more closely spaced primers as described at http://ccdb.ca/pricelist.php.

Three 96-well plates of specimens from the KNWR entomology collection were submitted to the CCDB using methods similar to UAM's. Additional KNWR sequences were obtained by collaboration, either through donation of KNWR specimens to taxonspecific DNA barcoding initiatives or facilitation of field sampling from KNWR by researchers working on DNA barcoding projects. 
A data archive in Arctos, the online database used by UAM and KNWR, of the voucher specimens DNA barcoded from UAM and the KNWR collections is at: http://arctos.database.museum/archive/knwr-uam-dna-barcoded. These data are also available via the BOLD website under the public project names UAMIC, UAMU, SPIAL, and KNWRA. This work was conducted using BOLD v3; however, BOLD v4 (in beta form) was introduced while results were being written up for publication. BOLD v4 has improvements and counts species differently than BOLD v3 (e.g. minor spelling errors, differences, or interim name codes, such as "sp.", were recognized as distinct species in BOLD v3). Our results presented herein were updated to values from BOLD v4. Records in the projects SPIAL, UAMIC, UAMU, and KNWRA have been submitted to GenBank (accession \#s HQ580516 - HQ580724, JN582182-JN582264, KU496677- KU496863, KU873129 - KU873924, KU873941 - KU876530); 160 sequences were flagged as problematic due to the presence of stop codons or suspected contamination, and thus not suitable to submit to GenBank. These are in BOLD project UAMF. Arctos shares data with iDigBio and the Global Biodiversity Information Facility (GBIF). In addition to label and identification data, the BOLD site contains images, DNA barcode sequences, primers, and trace files. All Arctos records are linked to their corresponding BOLD records (e.g. http://arctos.database.museum/guid/UAM:Ento:11800). Future improvements to BOLD will provide public reciprocal links to corresponding Arctos records as GenBank does. All DNA extractions made by CCDB were transferred to UAM and are stored in UAM's Genomic Resources collection for future use. We also count among our totals any records 
publicly available on BOLD for DNA barcoded species that were collected in Alaska but processed by other projects based on specimens stored in UAM or other institutions. These projects include PLNW (Platycheirus (Syrphidae) of the New World [Young et al. 2016]) and CNCTI (CNC Diptera 2012 - Tipulidae). Finally, to assess how thoroughly the entire Alaskan fauna has been DNA barcoded, we determined how many species which occur in Alaska have DNA barcodes in BOLD based on specimens not collected in Alaska. The vast majority of these records come from specimens in the Canadian National Collection (CNC).

The count of Alaskan non-marine arthropod species as represented by Barcode Index Numbers (BINs, Ratnasingham and Hebert (2013)) was obtained by submitting the search string “Arthropoda Alaska” into BOLD’s Public Data Portal on November 20, 2015, downloading the results, and selecting all records where the province was Alaska. Crustacea were excluded because this group contains both marine and non-marine species. The BIN system uses a set of algorithms to join DNA barcode sequences into Molecular Operational Taxonomic Units (MOTUs). These frequently correspond to species. Each MOTU is given a unique identifier - a BIN, linked to a DOI (Ratnasingham and Hebert 2013).

We performed a Barcode Gap Analysis of the UAMIC project after problematic records had been removed to project UAMF, which compares the maximum pairwise distance within each species to its nearest neighbour. Nearest neighbours are different species with the closest pairwise distances. We used default priors, restricted the analysis 
to sequences $\geq 500 \mathrm{bp}$ in length and used the BOLD aligner (Amino Acid based HMM) for the analysis.

A draft list of all non-marine arthropod species known from Alaska (N=8,277 as of 25 Nov 2015) is maintained by the first and second authors through the online database, Arctos. This list was used to assess thoroughness of our state-wide barcoding effort. An archive of the list used is at http://arctos.database.museum/saved/AKArthropoda-checklist-2016-01-14.

Testing the DNA barcode library of Alaskan non-marine arthropods. We established the public project UAMU in BOLD for 950 previously unidentified but recently collected (all under 5 years old) specimens submitted for identification via DNA barcodes. These comprised a sample of 190 Coleoptera, 569 Hymenoptera, and 190 Diptera specimens representing, a priori, an unknown number of species. Although not a truly random sample, these specimens met the criteria of being recently collected, unidentified, not easily identifiable by conventional methods, and belonging to on-going inventory projects for which identifications were being sought. These specimen records can be accessed via this URL: http://arctos.database.museum/project/uamu-dna-barcode-project. A summary of all taxa/identifications of these records is available at this URL http://arctos.database.museum/saved/DNA-Barcode-UAMU-taxa. At the time of this submission we had only obtained DNA barcodes for $\sim 1,000$ Alaskan species, which, combined with DNA barcodes already in BOLD for Alaskan species, represented ca. $40 \%$ of the Alaskan non-marine arthropod fauna. Thus, a priori, we expected to obtain 
species-level identifications for no more than $40 \%$ of the species in our sample.

Identification success was evaluated before records had been assigned to BINs so each sequenced specimen was queried against the BOLD ID engine's 'Species DB' (if none of the matches were within $99 \%$, the 'Full DB' search was used). We checked if the results of an ID search were consistent with the known higher taxon of the specimen (e.g. Coleoptera). We recorded the probability of placement to species, if available, and the $\%$ similarity range for all records matching the lowest taxon rank with a name among the results. We checked if the matching name was a taxon already known to occur in or near Alaska and flagged any that were not for further investigation. A species-level ID was scored a success if a match to a single species was at $98 \%$ or higher sequence similarity. If multiple species matched our unknown sequence at $98 \%$ sequence similarity or higher, we truncated the ID to the genus level and didn't count this as a species-level ID success but did count it as an identification improvement to the genus level. The same process was used to score identification improvements at higher ranks (e.g. family, again only using matches of $98 \%$ sequences similarity or higher).

\section{Results}

At the time of this study, UAM held specimens of 2,862 of the 8,277 known Alaskan non-marine arthropod species. Of these, 1,984 species are represented by specimens collected since 2002 and are thus ideal for DNA barcoding. The UAM Insect Collection submitted tissues from 4,845 photographed and databased specimens, of which 3,952 
yielded sequences, of which 3,273 were Barcode Compliant (sequence length of $>500 \mathrm{bp}$, $<1 \%$ ambiguous bases, two trace files, a minimum of low trace quality status as scored by BOLD, and the presence of a country specification in the record, as set out by the Consortium for DNA Barcoding). Excluding sequences $<100 \mathrm{bp}$ and flagged, problematic records, these sequences clustered into 1,625 BINs. A total of 7,927 trace files were generated from the UAMIC project, of which $57.0 \%$ were high quality, $10.5 \%$ medium quality, $6.96 \%$ low quality, and $25.55 \%$ failed. Sequence quality was high $(98.5 \%$ of sequences exhibited $<1 \% \mathrm{Ns}$ ), and sequence lengths for those that didn't fail entirely ranged from 77 - $658 \mathrm{bp}$, with an average length of $612 \mathrm{bp}(+/-103.7 \mathrm{SD})$, and a mode of $658 \mathrm{bp}$. Mean sequence composition was A-T rich, as expected for arthropods $(\mathrm{A}=$ $29.3 \%, \mathrm{C}=16.4 \%, \mathrm{G}=16.2 \%$, and $\mathrm{T}=38.1 \%)$.

The projects UAMIC and UAMU were based on 36 and 10 plates submitted to the CCDB, respectively. Museum and lab work for these two projects spanned the time frame January 2013 through June 2015. A summary of the results across the DNA barcoding projects presented here are in Table 1.

There are now 4,020 Alaskan species represented by DNA barcodes in BOLD i.e. $48.5 \%$ of the Alaskan non-marine arthropod fauna has species-level identified DNA barcodes. We obtained barcodes for members of seven orders that are known to have more than 100 species in Alaska (Fig. 3) and nine orders with fewer than 100 species in Alaska (Fig. 4). We did not obtain DNA barcodes from 18 of the terrestrial arthropod orders that are known from Alaska (Acari, Notostraca, Isopoda, Geophilomorpha, Lithobiomorpha, Julida, Polyxenida, Archaeognatha, Dermaptera, Blattodea, Diplura, 
Siphonaptera, Thysanoptera, Trichoptera, Zygentoma, Protura, Symphyla, Pauropoda). Although we attempted to obtain DNA barcodes from Dermaptera and Zygentoma specimens, they failed to sequence. The remaining 16 orders were not submitted for DNA barcoding due primarily to lack of suitable specimens.

The UAMIC project obtained DNA barcodes from 1,449 species which correspond to 1,342 BINs on BOLD. Our Barcode Gap Analysis of this project, after flagged records were removed, included 2,259 sequences, of which there were 149 species with high maximum within-species distances $(>2 \%)$ and 223 species with low minimum distances to other species $(<2 \%)$. The mean of the within-species mean uncorrected distances, based on sequences $>500 \mathrm{bp}$ in length, was $1.16 \%$, with a range of $0-21.27 \%$, and the mean nearest-neighbour distance was $9.4 \%$, with a range of $0-38.96 \%$. The mean of the within-species maximum distances was $1.26 \%$ with a range of 0 $22.85 \%$. Figure 5 illustrates 340 p-distance comparisons for species of which we had both multiple specimens DNA barcoded and multiple congeners DNA barcoded (see withinspecies distances in Supplementary Material).

At present, a total of 2,251 non-marine arthropod BINs (excluding Crustacea) have been collected from Alaska and made publicly available on BOLD. Within the UAMIC project, a BIN discordance report indicated that 611 of this project's 1,342 BINs are taxonomically discordant (BIN shared by more than one taxon in BOLD v3 across all projects), 660 are taxonomically concordant (BIN contains multiple records of one taxon), and 89 BINs are singletons containing only one sequence. An example of the latter category is the BIN BOLD:ACS6051 that contains a sequence from one specimen 
of the omaliine staphylinid beetle, Micralymma brevilingue Schiødte, 1845, collected on St. Matthew Island in the Bering Sea (Fig. 6). There are other sequences of this species in the BOLD database, but they fall into a different, nearest-neighbour (6.81\% p-dist.), BIN (BOLD:ACA4418) based on specimens collected in Greenland.

The test of the library using 950 unidentified specimens resulted in 803 DNA barcode sequences after problematic records were removed (UAMU project, Table 1) of which 653 were DNA Barcode Compliant. The sequences from these specimens fell into 240 BINs, and 58 of these BINs yielded confident species-level identifications $(24 \%$ of 240). There was a fairly large difference between orders in the success of identification. Of the Diptera, $42 \%$ of the specimens were identified to species, while only $23 \%$ of the Hymenoptera specimens and $23 \%$ of the Coleoptera specimens could be identified to that level. Of 803 specimens that yielded DNA sequences, 241 saw some identification improvements at the family level, 474 at the genus level, and 256 at the species level. Overall, 609 records saw identification improvement at some level (75.8\%).

\section{Discussion}

This work represents an important step in the documentation of Alaska's biota and lays a foundation for future research and biomonitoring. Prior to our work, no state or province in North America had begun a project to obtain DNA barcodes for their entire arthropod fauna. Our efforts, combined with those of others contributing data to the Barcode of Life Data Systems, BOLD, have resulted in DNA barcodes for almost half of the known Alaskan non-marine arthropods. 
However, our results also demonstrate the need for additional integrative taxonomic revisionary work to help resolve the discordance we documented. There are various explanations for the 611 BINs (46\% of the total) with discordant taxonomy (BIN sharing) in the UAMIC project. Some discordance is due to simple differences in spellings (e.g. Amerizus oblongulus (Mannerheim, 1852) vs. Amerizus oblongulum (Mannerheim, 1852), the former is correct according to Bousquet et al. (2013)); some is due to different taxonomic classifications (e.g. Aedes vs. Ochlerotatus; Ips vs. Pseudips); some is likely due to misidentifications, lab errors (e.g. contaminations), young / incipient species (haplotype sharing, introgresssion), Wolbachia infection, or taxonomic oversplitting (species which should be synonymized). BOLD staff members routinely examine discordant BINs and work with BOLD project managers to resolve them. BIN discordance documents the problem of multiple Linnaean names with low genetic divergence. We also discovered 275 species with higher than normal ( $>2 \%$, Zhou et al. 2009) maximum within-species divergence (Fig. 5). Explanations for these results also include possible misidentifications (two or more different species identified as the same prior to DNA barcoding) or lab errors, but some may result from taxonomic undersplitting (e.g., cryptic, unrecognized species) or represent species with aboveaverage genetic diversity. Examination of BOLD-generated neighbour-joining trees to determine if the component taxa form reciprocally-monophyletic clusters is a first step towards resolving these.

An example of the category of potentially cryptic species is the circumpolar, arctic species Micralymma brevilingue, mentioned in the results (Fig. 6). The Greenland 
samples in BOLD for this wingless species form a monophyletic sister cluster to the one Alaskan sample, which is almost $7 \%$ divergent, and thus likely not conspecific. Further examination of this case, including examination of type specimens and greater genetic sampling from Alaska and Siberia, might lead to the resurrection of the currently invalid name Micralymma dicksoni Mäklin (1881), known from arctic Siberia and the Alaskan Pribilof Islands, as valid. Even such brief examination of the hundreds of other similar cases unearthed by this project is beyond the scope of this paper.

Because BOLD requires specimen vouchers for all DNA barcodes, in theory, each discordant BIN can be investigated and resolved. This will be an enormous undertaking, requiring the taxonomic study of many hundreds or thousands of specimens from dozens of different institutions. This will ideally be undertaken one higher taxon at a time, with collaboration of one or more taxonomists focused on each group.

Sampling coverage was not even across higher taxa. The major aquatic insect orders Ephemeroptera, Plecoptera, and Trichoptera were not well sampled (Fig. 4) nor were orders with rare, small, soft-bodied, or parasitic species (e.g. Diplura, Acari, Siphonaptera). Aquatic insects in Alaska are of great interest to ecologists and fisheries biologists (e.g. Roon et al. 2014), and we hope future DNA barcoding efforts in Alaska will focus more on these taxa.

The UAMU project to test the barcode library resulted in 240 BINs, of which $24 \%$ have species-level identifications. This is within our a priori expectation of no more than $40 \%$, but somewhat lower than hoped, perhaps as a result of our submitted unknowns not corresponding proportionally to the taxa used to build the library. If we 
had submitted unknowns in the same proportions as illustrated in Figure 2 (Coleoptera: 6.7, Diptera: 2.8 , Hymenoptera: 1), the success rate may have been closer to $40 \%$. To further clarify this point, if we had submitted only Collembola, Plecoptera, and Ephemeroptera as unknowns this would have been a poor test of the library because these orders contain very few of the species we added to the DNA barcode library. As the DNA barcode library for northern North American arthropods approaches completion, which will require taxonomic revision and new descriptions of many taxa, all 803 sequences in these 240 BINs should receive species-level identifications eventually.

Our project has laid the foundation of a statewide reference library with which to compare future barcodes for identifying non-marine arthropods in Alaska. While not representative of all areas of Alaska, our collaboration has ensured good representation from the Fairbanks and Kenai areas (Fig. 1), a reasonable cross-section of the boreal biome. We are also planning future research to target taxa for DNA barcoding that were undersampled in this effort including Ephemeroptera, Plecoptera, and Trichoptera.

We can foresee multiple applications of our DNA barcode library both immediately and in the near future, including setting the stage for studies that use DNA barcodes to facilitate identification of otherwise cryptic material (e.g., fecal or stomach content analysis); to facilitate citizen science (e.g., using LifeScanner); better forest pest monitoring (Early Detection Rapid Response, Forest Health Protection programs); phylogeographic studies, such as through comparison with other northern barcode-based inventories (e.g. Zhou et al. 2009, Wirta et al. 2016); and inventory and monitoring of 
biodiversity using next-generation sequencing metabarcoding analysis of arthropod assemblages in environmental samples (e.g., in future iterations of LTEMP).

\section{Acknowledgements}

We thank the 164 entomologists and arachnologists who identified specimens from which we obtained or attempted to obtain DNA barcodes, including those who obtained DNA barcodes from UAM or KNWR specimens as part of their own projects: J. Acorn, R. Anderson, G. Anweiler, A. Asmus, G. Ball, K. Barber, J. Barnes, C. Bartlett, A. Bennett, J. Bergdhal, E. Bernard, G. Blagoev, D. Bogan, R. Borth, P. Bouchard, C. Boudreault, F. Brodo, S. Brooks, D. Buckle, C. Buddle, M. Buffington, J. Campbell, J. Carpenter, P. Catling, S. Chatzimanolis, S. Chuluunbat, A. Cline, D. Collet, C. Coon, J. Cornell, S. Cover, R. Crawford, J. Cumming, D. Currie, K. Daly, R. Darsie, R. Davidson, A. Davies, G. Delvare, C. Dietrich, H. Douglas, M. Draney, T. Ekrem, S. Emmert, T. Eskelin, J.-L. Fernandez Triana, M. Ferrer-Suay, C. Ferris, M. Ferro, A. Finnamore, B. Fisher, A. Fjellberg, B. Fleshman, O. Flint, B. Foote, A. Francoeur, Z. Fric, M. Furniss, J. Goodwin, H. Goulet, D. Guinn, A. Hagerty, K. Hamilton, H. Hammond, E. Hoebeke, J. Hudson, P. Huemer, S. Huguet, O. Jaeger, K. Johnson, P. Johnson, J. Johnson, D. Kavanaugh, J. Klimaszewski, S. Klopfstein, J. Koch, V. Kolyada, V. Kolyada, J. Kruse, J. LaBonte, J. Lafontaine, J.-F. Landry, R. Leschen, T. Lewis, S. Lingafelter, M. Locke, I. MacDougall, T. MacRae, D. Maddison, J. Martin, L. Masner, W. Mathis, H. Maw, T. McElrath, I. Meijer Drees, V. Michelsen, Y. Mikhailov, E. Mockford, K. Moran, L. 
Mullen, E. Munroe, W. Murphy, P. Naskrecki, A. Newton, J. Noyes, C. O'Brien, L. O'Brien, M. Olmi, P. Opler, B. Owens, L. Packer, R. Pampell, M. Paulsen, S. Peek, P. Perkins, K. Philip, K. Pike, D. Pollock, F. Purrington, A. Ramsdale, A. Ray, A. Renaud, K. Renner, S. Ridling, E. Riley, J. Rivera, J. Rohácek, W. Rücker, D. Ruiter, J. Runyon, D. Saltmarsh, M. Schwartz, G. Scudder, D. Shain, M. Sharkey, A. Shavrin, C. Sheffield, R. Shelley, B. Sinclair, P. Skelley, J. Skevington, J. Slowik, A. Smetana, D. Smith, P. Starý, G. Steck, K. Stewart, J. Stockbridge, M. Sutou, M. Thayer, M. Thomas, F. Thompson, L. Toledano, E. Trainor, J. Vockeroth, R. Westcott, T. Whitworth, J. Willacker, P. Williams, S. Wise-Eagle, T. Woldstad, N. Woodley, D. Wrase, A. Young, C. Young. We also thank the staff of the Canadian Centre for DNA Barcoding, University of Guelph, for conducting molecular lab work, and Dusty McDonald for programming support with Arctos. We thank all the wonderful lab technicians who helped with specimen preparation. Funding was provided by the United States Fish and Wildlife Service's Alaska Region NWRS Inventory and Monitoring Initiative, and the Alaska Department of Fish and Game's Wildlife Diversity Program. Sequence analysis was aided by funding from the Government of Canada through Genome Canada and the Ontario Genomics Institute in support of the International Barcode of Life project.

\section{References}

Bálint, M., Domisch, S., Engelhardt, C.H.M., Haase1, P., Lehrian, S., Sauer, J., Theissinger, K., Pauls S.U. and Nowak, C. 2011. Cryptic biodiversity loss linked 
to global climate change. Nature Climate Change 1: 313-318.

doi: $\underline{10.1038 / \text { nclimate1191 }}$

Beck, P.S.A., Juday, G.P., Alix, C., Barber, V.A., Winslow, S.E., Sousa, E.E., Heiser, P., Herriges, J.D., and Goetz, S.J. 2011. Changes in forest productivity across Alaska consistent with biome shift. Ecology Letters 14: 373-379. doi: 10.1111/j.1461$\underline{0248.2011 .01598 . \mathrm{X}}$

Behan, V.M. 1978. Diversity, distribution and feeding habits of North American arctic soil Acari. Unpublished Ph.D. thesis, McGill Univ., Montreal, 428 pp.

Bousquet, Y., Bouchard, P., Davies, A.E., and Sikes, D.S. 2013. Checklist of Beetles (Coleoptera) of Canada and Alaska. Second Edition. Pensoft Series Faunistica No 109, Sofia-Moscow, 402 pp. ISSN 1312-0174, ISBN 978-954-642-704-5

Bowser, M.L. 2012. Update on the 2011 Kenai Arthropod Rapid Ecological Assessment. Newsletter of the Alaska Entomological Society 5: 15-20. http://www.akentsoc.org/doc/AKES newsletter 2012 I.pdf

Bowser, M., and Morton, J.M. 2009. Monitoring and modeling terrestrial arthropod diversity on the Kenai National Wildlife Refuge. In 2008 Forest Inventory and Analysis (FIA) Symposium, October 21-23, 2008; Park City, UT. Edited by McWilliams, W., Moisen, G., and Czaplewski, R. U.S. Department of Agriculture, Forest Service, Rocky Mountain Research Station, Fort Collins, Colo. Proc. RMRS-P-56CD. http://www.treesearch.fs.fed.us/pubs/33333 
Chapin, F.S. III, Oswood, M.W., Van Cleve, K., Viereck, L.A., and Verbyla, D.L. (eds). 2006. Alaska’s Changing Boreal Forest. Oxford University Press, New York. xiv $+354 \mathrm{pp}$.

Chown, S.L., Sinclair, B.J. and van Vuuren, B.J. 2008. DNA barcoding and the documentation of alien species establishment on sub-Antarctic Marion Island. Polar Biology. 31: 651-655. doi: $10.1007 / \mathrm{s} 00300-007-0402-\mathrm{Z}$

deWaard, J.R., Ivanova, N.V., Hajibabaei, M., and Hebert, P.D.N. 2008. Assembling DNA barcodes: analytical protocols. In Martin, C., editor. Methods in molecular biology: environmental genetics. Totowa: Humana Press. pp. 275-293.

Geiger, M.F., Astrin, J.J., Borsch, T., Burkhardt, U., Grobe, P., Hand, R., Hausmann, A., Hohberg, K., Krogmann, L., Lutz, M., Monje, C., Misof, B., Morinière, J., Müller, K.F., Pietsch, S., Quandt, D., Rulik, B., Scholler, M., Traunspurger, W., Haszprunar, G., Wägele, W. In press. How to tackle the molecular species inventory for an industrialized nation - lessons from the first phase of the German Barcode of Life initiative GBOL (2012-2015). Genome. doi: 10.1139/gen-20150185

Gruppe, A., Hendrich, L. and J. Morinière. 2014. Barcoding Fauna Bavarica - Erste Ergebnisse zu den Neuropterida Bayerns.- DGaaE-Nachrichten. 28: 22-23.

Gwiazdowski, R.A., Foottit, R.G., Maw, H.E.L., Hebert, P.D.N. 2015. The Hemiptera (Insecta) of Canada: Constructing a Reference Library of DNA Barcodes. PLoS ONE 10: e0125635. doi:10.1371/journal.pone.0125635 
Hausmann, A., Haszprunar,G., Hebert, P.D.N. 2011. DNA Barcoding the Geometrid fauna of Bavaria (Lepidoptera): Successes, surprises, and questions. PLoS ONE 6(2): e17134. doi:10.1371/journal.pone.0017134

Hausmann, A., Haszprunar, G., Segerer, A. H., Speidel, W., Behounek, G., \& Hebert, P. D. 2011. Now DNA-barcoded: the butterflies and larger moths of Germany. Spixiana, 34(1), 47-58.

Hebert, P.D.N., deWaard, J.R., Zakharov, E.V., Prosser, S.W.J., Sones, J.E., et al. 2013. A DNA 'Barcode Blitz': Rapid Digitization and Sequencing of a Natural History Collection. PLoS ONE. 8: e68535. doi:10.1371/journal.pone.0068535

Hendrich, L., Pons, J., Ribera, I., Balke, M. 2010. Mitochondrial Cox1 sequence data reliably uncover patterns of insect diversity but suffer from high lineageidiosyncratic error rates. PLoS ONE. 5: e14448. doi: $10.1371 /$ journal.pone.0014448

Ivanova, N.V., deWaard, J.R., Hebert, P.D.N. 2006. An inexpensive, automationfriendly protocol for recovering high-quality DNA. Molecular Ecology Notes 6: 998-1002. doi: $10.1111 / \mathrm{j} .1471-8286.2006 .01428 . \mathrm{x}$

Ives, J.D. 1974. Biological refugia and the nunatuk hypothesis. In: Ives, J.D., Barry, R.G. (eds) Arctic and Alpine Environments. Metheun, London, 605-636. doi:10.1111/j.1471-8286.2006.01428.x

Ji, Y., Ashton, L., Pedley, S.M., Edwards, D.P., Tang, Y., Nakamura, A., Kitching, R., Dolman, P.M., Woodcock, P., Edwards, F.A., Larsen, T.H., Hsu, W.W., Benedick, S., Hamer, K.C., Wilcove, D.S., Bruce, C, Wang, X., Levi, T., Lott, 
M., Emerson, B.C., Yu, D.W. 2013. Reliable, verifiable and efficient monitoring of biodiversity via metabarcoding. Ecology Letters. 16: 1245-1257. doi: $\underline{10.1111 / \text { ele. } 12162}$

Juday, G.P., Alix, C., and Grant, T.A. III. 2015 Spatial coherence and change of opposite white spruce temperature sensitivities on floodplains in Alaska confirms earlystage boreal biome shift. Forest Ecology and Management. 350: 46-61. http://dx.doi.org/10.1016/j.foreco.2015.04.016

Lawrence, D.M., and Slater, A.G. 2005 A projection of severe near-surface permafrost degradation during the 21 st century. Geophysical Research Letters. 32: L24401, doi:10.1029/2005GL025080.

Matthews, J.V., Jr. 1975. Insects and plant macrofossils from two quaternary exposures in the old crow-porcupine region, Yukon Territory, Canada. Arctic and Alpine Research 7: 249-259. doi: 10.2307/1550000

McGuire, A.D., Anderson, L.G., Christensen, T.R., Dallimore, S., Guo, L., Hayes, D.J., Heimann, M., Lorenson, T.D., Macdonald, R.W., and Roulet, N. 2009. Sensitivity of the carbon cycle in the Arctic to climate change. Ecological Monographs. 79: 523-555. doi: $10.1890 / 08-2025.1$

Morton, J.M., Bowser, M.L., Berg, E., Magness, D., and Eskelin, T. 2009. Long term ecological monitoring program on the Kenai National Wildlife Refuge, Alaska: an FIA adjunct inventory. In 2008 Forest Inventory and Analysis (FIA) Symposium, October 21-23, 2008; Park City, UT. Edited by McWilliams, W., Moisen, G., and Czaplewski, R. U.S. Department of Agriculture, Forest Service, Rocky Mountain 
Research Station, Fort Collins, Colo. Proc. RMRS-P-56CD.

http://www.treesearch.fs.fed.us/pubs/33332

Pielou, E.C. 1991. After the Ice Age: The return of life to glaciated North America. The University of Chicago Press, 366 pp. doi:

10.7208/chicago/9780226668093.001.0001

Pons, J. 2006. DNA-based identification of preys from non-destructive, total DNA extractions of predators using arthropod universal primers. Molecular Ecology Notes, 6: 623-626. doi: 10.1111/j.1471-8286.2006.01353.x

Ratnasingham, S., and Hebert, P.D.N. 2007. Bold: The Barcode of Life Data System (http://www.barcodinglife.org). Molecular Ecology Notes. 7(3):355-364. doi:10.1111/j.1471-8286.2007.01678.x.

Ratnasingham, S., and Hebert, P.D.N. 2013. A DNA-based registry for all animal species: The Barcode Index Number (BIN) System. PLoS ONE. 8: e66213. doi: $10.1371 /$ journal.pone.0066213

Raupach, M.J., Hendrich, L., Küchler, S.M., Deister, F., Moriniere, J., et al. 2014. Building-up of a DNA barcode library for true bugs (Insecta: Hemiptera: Heteroptera) of Germany reveals taxonomic uncertainties and surprises. PLoS ONE. 9: e106940. doi:10.1371/journal.pone.0106940

Roon, D.A., Wipfli, M.S., and Wurtz, T.L. 2014. Effects of invasive European bird cherry (Prunus padus) on leaf litter processing by aquatic invertebrate shredder communities in urban Alaskan streams. Hydrobiologia. 736: 17-30. doi:10.1007/s10750-014-1881-X 
Serreze, M.C., Walsh, J.E., Chapin, F.S. III, Osterkamp, T., Dyurgerov, M., Romanovsky, V., Oechel, W.C., Morison, J., Zhang, T., and Barry, R.G. 2000. Observational evidence of recent change in the northern high-latitude environment. Climatic Change. 46: 159-207. doi:10.1023/A:1005504031923

Sikes, D.S., Allen, R.T. 2016. First Alaskan records and a significant northern range extension for two species of Diplura (Diplura, Campodeidae). ZooKeys 563: 147157. doi: $10.3897 /$ zookeys.563.6404

Slowik, J. and Blagoev, G.A. 2012. First description of the male spider Pacifiphantes magnificus (Chamberlin \& Ivie) (Araneae: Linyphiidae). Zootaxa. 3481: 73-81.

Spelda, J., Reip, H., Biener, U. O., \& Melzer, R. 2011. Barcoding Fauna Bavarica: Myriapoda-a contribution to DNA sequence-based identifications of centipedes and millipedes (Chilopoda, Diplopoda). ZooKeys 156: 123-139. doi: 10.3897/zookeys. 156.2176

Stone, R.S., Dutton, E.G., Harris, J.M., and Longenecker, D. 2002. Earlier spring snowmelt in northern Alaska as an indicator of climate change. Journal of Geophysical Research: Atmospheres (1984-2012), 107: (D10), ACL-10. doi: $\underline{10.1029 / 2000 J D 000286}$

Sturm, M., Schimel, J., Mechaelson, G., Welker, J.M., Oberbauer, S.F., Liston, L.E., Fahnestock, J., and Romanovsky, V.E. 2005. Winter biological processes could help convert Arctic tundra to shrubland. BioScience 55: 17-26. doi:10.1641/00063568(2005)055[0017:WBPCHC]2.0.CO;2 
US Global Change Research Program, National Assessment. 2001. Overview: Alaska. http://www.globalchange.gov/component/content/article/52-reports-andassessments/476-overview-alaska

Valentini, A., Pompanon, F., Taberlet, P. 2009. DNA barcoding for ecologists. Trends in Ecology \& Evolution 24(2):110-117 doi:10.1016/j.tree.2008.09.011.

Wirta, H., Várkonyi, G., Rasmussen, C., Kaartinen, R., Schmidt, N. M., Hebert, P. D. N., Barták, M., Blagoev, G., Disney, H., Ertl, S., Gjelstrup, P., Gwiazdowicz, D. J., Huldén, L., Ilmonen, J., Jakovlev, J., Jaschhof, M., Kahanpää, J., Kankaanpää, T., Krogh, P. H., Labbee, R., Lettner, C., Michelsen, V., Nielsen, S. A., Nielsen, T. R., Paasivirta, L., Pedersen, S., Pohjoismäki, J., Salmela, J., Vilkamaa, P., Väre, H., von Tschirnhaus, M. and Roslin, T. 2016. Establishing a community-wide DNA barcode library as a new tool for arctic research. Molecular Ecology Resources, 16: 809-822. doi: 10.1111/1755-0998.12489

Young, A.D., S.A. Marshall, J.H. Skevington. 2016. Revision of Platycheirus Lepeletier and Serville (Diptera: Syrphidae) in the Nearctic north of Mexico. ZooTaxa 4082: 1-317 doi: 10.11646/zootaxa.4082.1.1

Veblen, T.T., and Alaback, P.B. 1996. A comparative review of forest dynamics and disturbance in the temperate rainforests of North and South America. Pages 173213 in Lawford, R.G., Alaback, P.B., and Fuentes, E. (eds.) High-latitude rainforests and associated ecosystems of the west coast of the Americas: climate, hydrology, ecology, and conservation. Springer, New York. 
Zhou, X., Adamowicz, S., Jacobus, L., DeWalt, R. E. \& Hebert, P. D. N. 2009. Towards a comprehensive barcode library for arctic life-Ephemeroptera, Plecoptera, and Trichoptera of Churchill, Manitoba, Canada. Front. Zool. 6, e30. doi:10.1186/ 1742-9994-6-30) 
Table 1. Summary of results from different DNA barcoding BOLD projects reported. UAMIC $=$ University of Alaska Museum Insect Collection, UAMU = University of Alaska Museum Unidentifieds, SPIAL = Spiders of Alaska, KNWRA = Arthropods of the Kenai National Wildlife Refuge. \# of species submitted provides counts based on species identified to species level prior to submission. \# of specimens submitted are counts after problematic records had been removed from the project. NA $=$ not applicable.

\begin{tabular}{lllll}
\hline $\begin{array}{l}\text { Project } \\
\text { acronym }\end{array}$ & $\begin{array}{l}\text { \# of specimens } \\
\text { submitted }\end{array}$ & $\begin{array}{l}\text { \# of specimens } \\
\text { success }(\%)\end{array}$ & $\begin{array}{l}\text { \# species } \\
\text { submitted }\end{array}$ & $\begin{array}{l}\text { \#species } \\
\text { success }(\%)\end{array}$ \\
\hline UAMIC & 3,281 & $2,607(80.3 \%)$ & 1,674 & $1,449(86.5 \%)$ \\
UAMU & 928 & $803(86.5 \%)$ & 0 & NA \\
SPIAL & 281 & $208(74 \%)$ & 72 & $68(94.4 \%)$ \\
KNWRA & 286 & $270(94.4 \%)$ & 267 & $253(94.8 \%)$ \\
Total & $\mathbf{4 , 7 7 6}$ & $\mathbf{3 , 8 8 8}(\mathbf{8 1 . 4 \% )}$ & $\mathbf{1 , 8 8 2}$ & $\mathbf{1 , 6 6 2 ( 8 8 . 3 \% )}$ \\
\hline
\end{tabular}


Figure Captions

Figure 1. Count of specimens DNA barcoded from UAM and KNWR by year of specimen collection.

Figure 2. Map showing locations from which 4,239 Alaskan DNA barcoded specimens stored in UAM or KNWR were collected. Colored circles indicate geocoordinate uncertainty (error) with red circles for KNWR records and blue circles for UAM records. Green areas on the map denote US Federal lands (e.g. National Park Service, National Wildlife Refuge, and National Forest lands).

Figure 3. Large orders of arthropods with Alaskan specimens in UAM showing the number of species known from Alaska in black, the number of authoritatively identified species with specimens in UAM that had been collected since 2002 (light grey), and the number of these species that were DNA barcoded (cross-hatch patterned) based on UAM specimens.

Figure. 4. Small orders of arthropods with Alaskan specimens in UAM showing the number of species known from Alaska in black, the number of authoritatively identified species with specimens in UAM that had been collected since 2002 (light grey), and the 
number of these species that were DNA barcoded (cross-hatch patterned) based on UAM specimens.

Figure 5. Maximum within-species p-distances versus minimum among-congeneric species p-distances for 340 comparisons of UAMIC records for which we had DNA barcodes for multiple species within a genus and for multiple specimens within a species. Quadrants represent: I. consistent with current taxonomy (n=147); II. possible species undersplitting (candidates for taxonomic split) or misidentifications ( $\mathrm{n}=44)$; III. recent divergence, hybridization, or possible species oversplitting (candidates for synonymy) $(n=92)$; IV. possible misidentifications $(n=57)$. All within-species comparisons were made after excluding records not identified to species. Uncorrected pairwise distances were aligned using the amino-acid based BOLD alignment and limited to sequences 500 bp or longer in length.

Figure 6. Micralymma brevilingue Schiødte, 1845. DNA barcode voucher, UAM specimen UAM:Ento:243942 


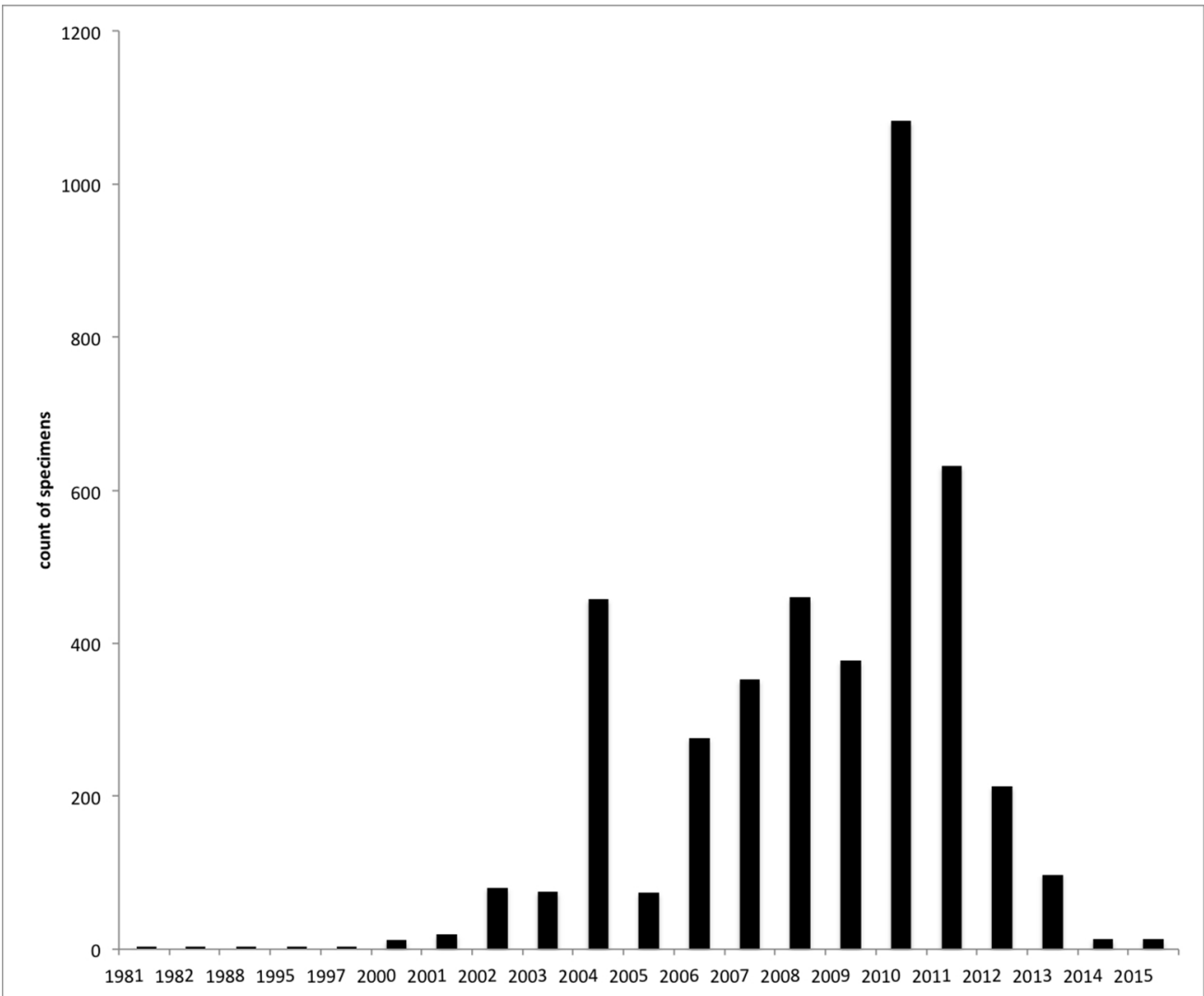

Figure 1. Count of specimens DNA barcoded from UAM and KNWR by year of specimen collection. 


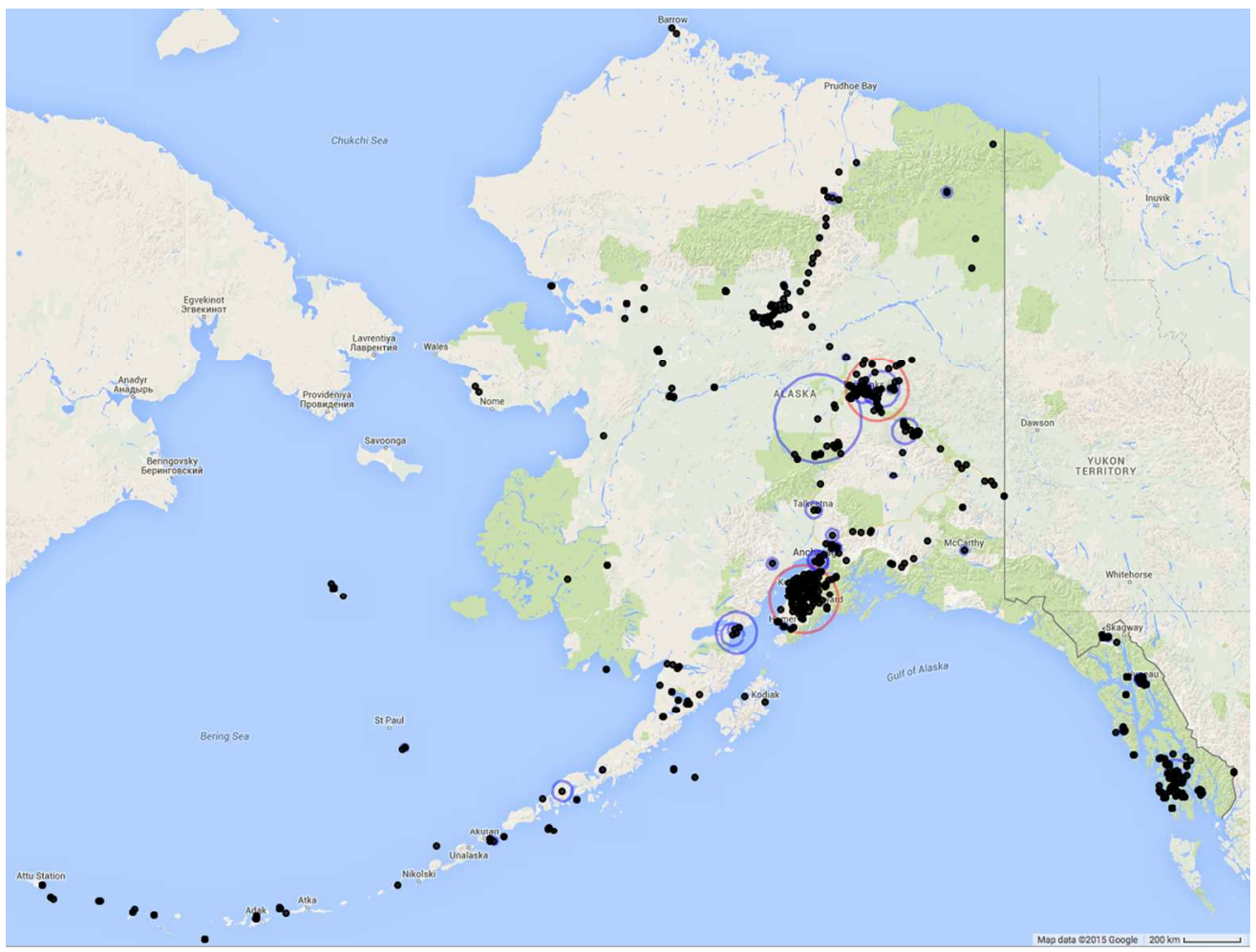

Figure 2. Map showing locations from which 4,239 Alaskan DNA barcoded specimens stored in UAM or KNWR were collected. Colored circles indicate geocoordinate uncertainty (error) with red circles for KNWR records and blue circles for UAM records. Green areas on the map denote US Federal lands (e.g. National Park Service, National Wildlife Refuge, and National Forest lands).

$127 \times 95 \mathrm{~mm}(300 \times 300 \mathrm{DPI})$ 


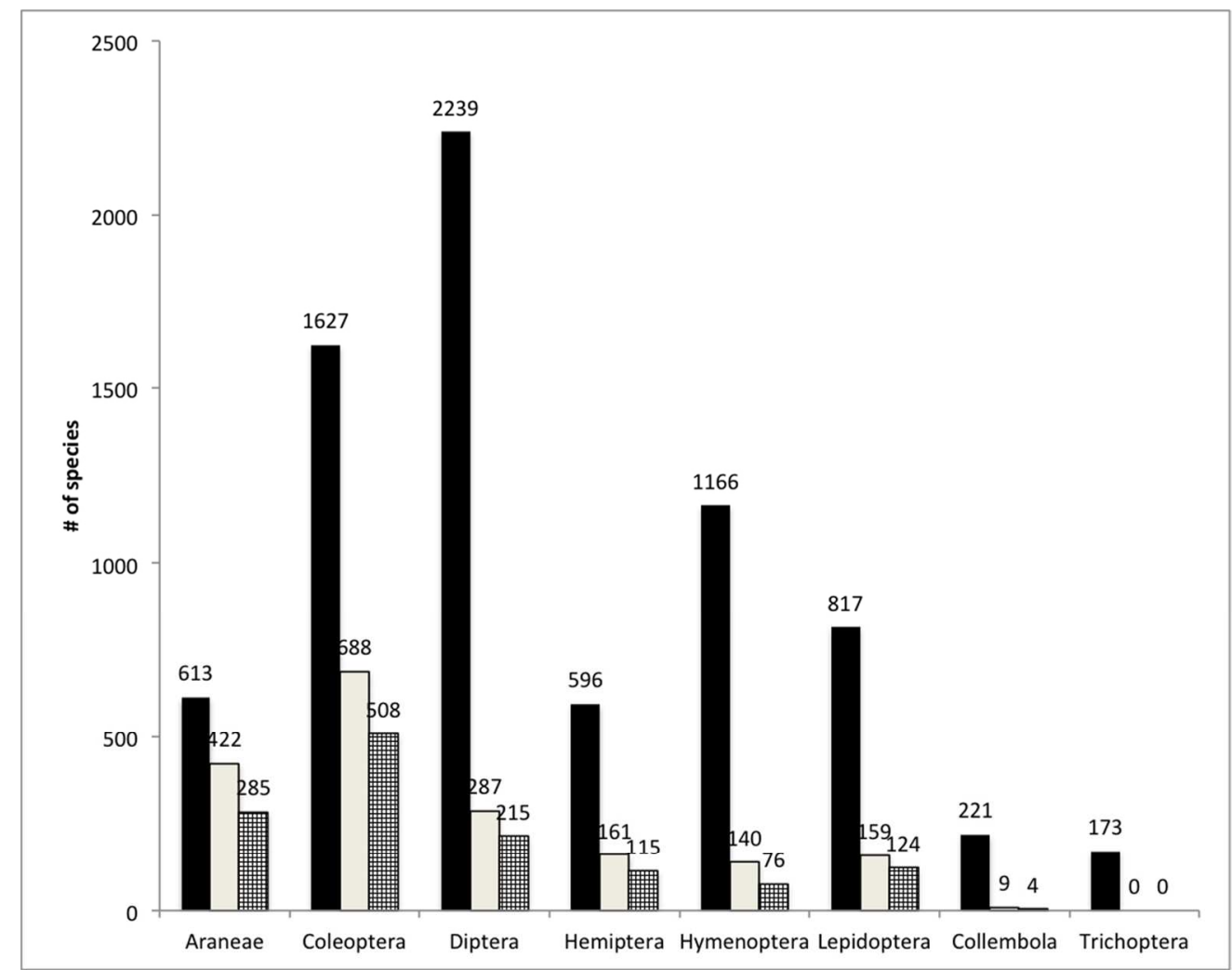

Figure 3. Large orders of arthropods with Alaskan specimens in UAM showing the number of species known from Alaska in black, the number of authoritatively identified species with specimens in UAM that had been collected since 2002 (light grey) and the number of these species that were DNA barcoded (cross-hatch patterned) based on UAM specimens.

$127 \times 100 \mathrm{~mm}(300 \times 300 \mathrm{DPI})$ 


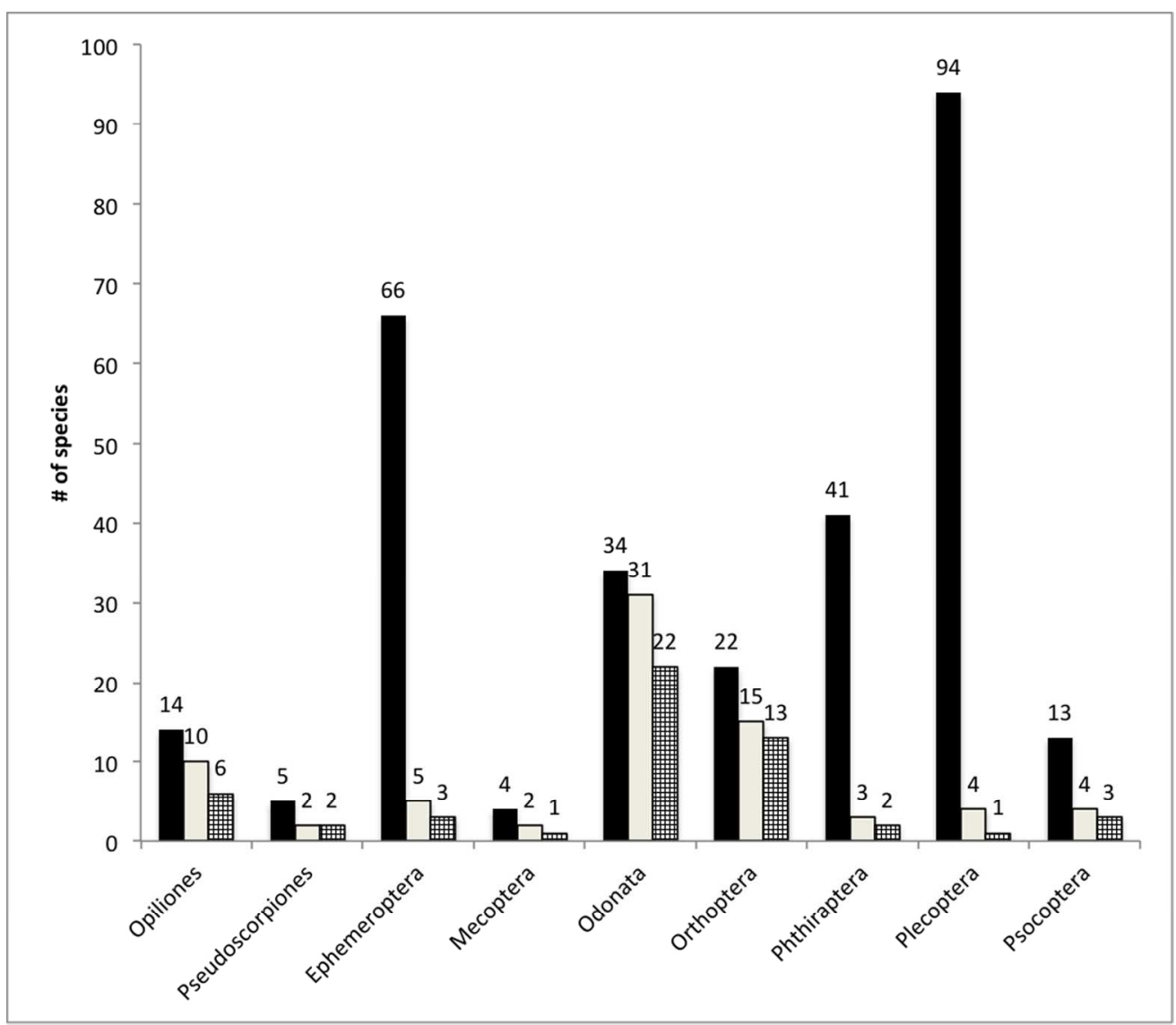

Figure. 4. Small orders of arthropods with Alaskan specimens in UAM showing the number of species known from Alaska in black, the number of authoritatively identified species with specimens in UAM that had been collected since 2002 (light grey) and the number of these species that were DNA barcoded (cross-hatch patterned) based on UAM specimens.

$127 \times 110 \mathrm{~mm}(300 \times 300 \mathrm{DPI})$ 


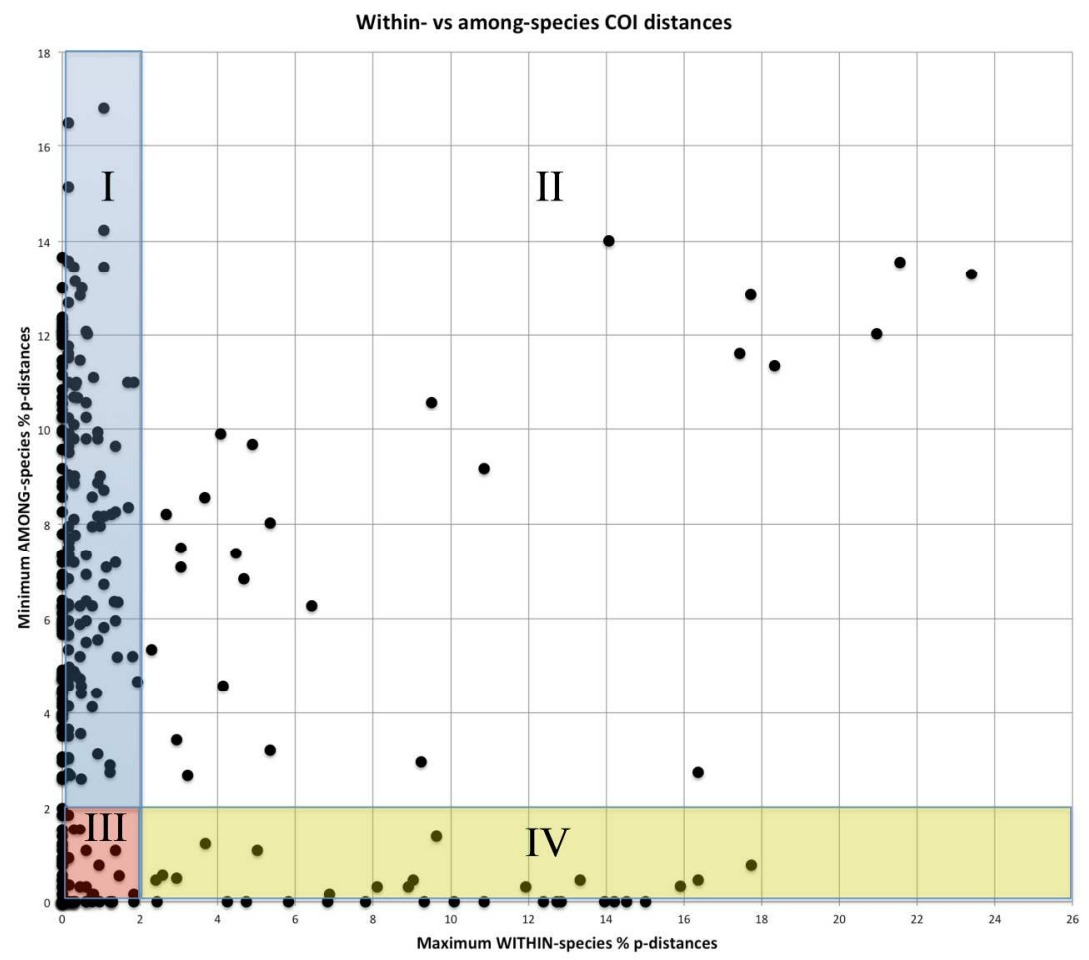

Figure 5. Maximum within-species $p$-distances versus minimum among-congeneric species $p$-distances for 340 comparisons of UAMIC records for which we had DNA barcodes for multiple species within a genus and for multiple specimens within a species. Quadrants represent: I. consistent with current taxonomy ( $n=147)$; II. possible species undersplitting (candidates for taxonomic split) or misidentifications $(n=44)$; III. recent divergence, hybridization, or possible species oversplitting (candidates for synonymy) ( $n=92)$; IV. possible misidentifications $(n=57)$. All within-species comparisons were made after excluding records not identified to species. Uncorrected pairwise distances were aligned using the amino-acid based BOLD alignment and limited to sequences 500 bp or longer in length.

$254 \times 190 \mathrm{~mm}(300 \times 300 \mathrm{DPI})$ 


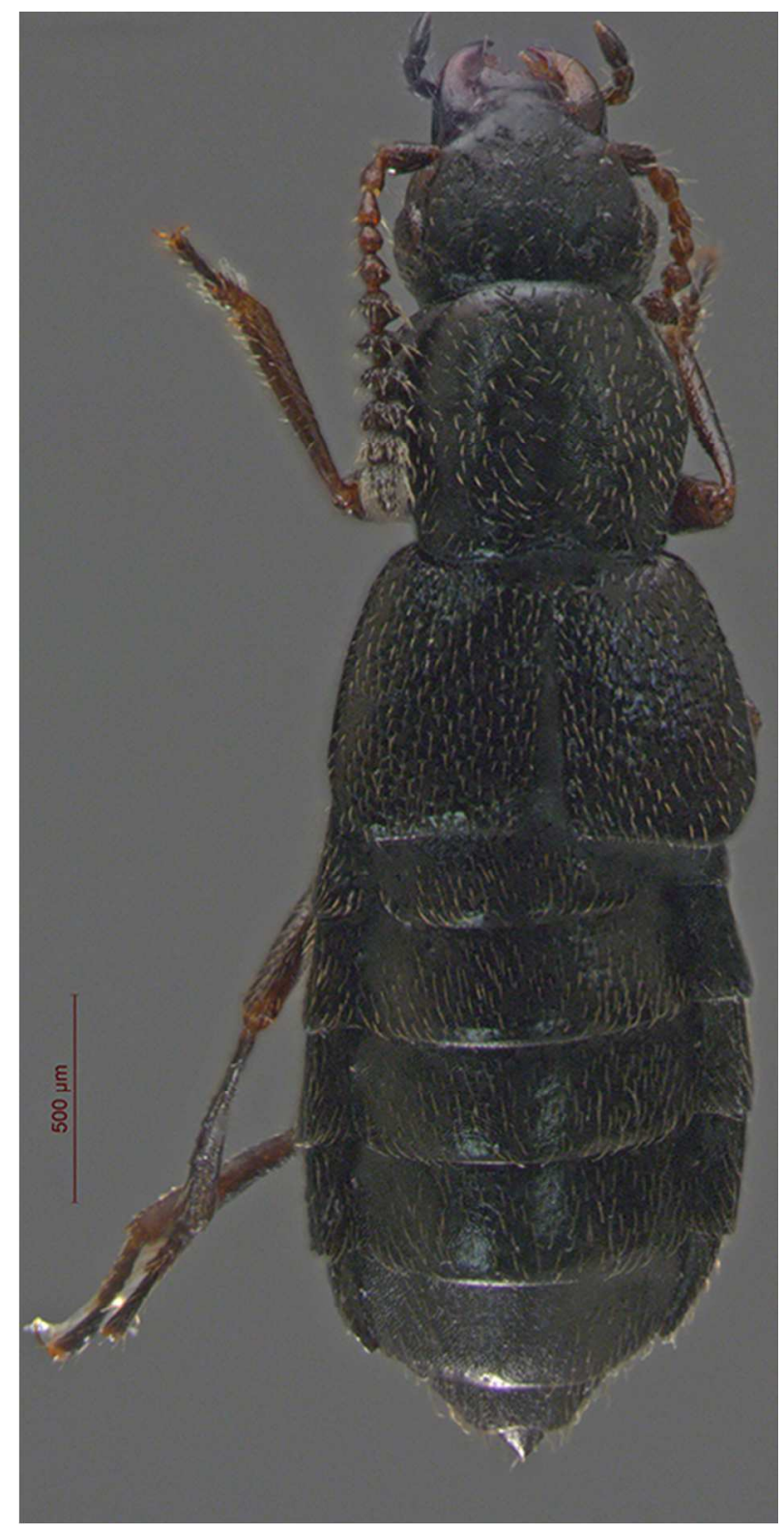

Figure 6. Example of a potentially cryptic species based on DNA barcode evidence. Currently under the name Micralymma brevilingue Schiødte, 1845. This Alaskan specimen might belong to a separate species under the currently invalid name Micralymma dicksoni Mäklin (1881). DNA barcode voucher, UAM specimen UAM:Ento:243942.

$38 \times 75 \mathrm{~mm}(300 \times 300$ DPI $)$ 
Supplementary Material - uncorrected pairwise within species distances

All within-species comparisons were made after excluding records not identified to species.

Uncorrected pairwise distances were aligned using the amino-acid based BOLD

alignment and limited to sequences $500 \mathrm{bp}$ or longer in length.

\section{species}

Orthotylus katmai

Pseudohylesinus tsugae

Pseudohylesinus tsugae

Quedius fulvicollis

Quedius fulvicollis

Hylurgops rugipennis

Hylurgops rugipennis

Quedius simulator

Sminthurinus concolor

Irbisia sericans

Tetragnatha laboriosa

Dyschirius politus politus

Irbisia sericans

Phlaeopterus lagrandeuri

Bembidion arcticum

Tetragnatha laboriosa

Atheta prudhoensis

Boreostiba websteri

Coelopa stejnegeri

Atheta capsularis

Atheta prudhoensis

Tetragnatha extensa

Lypoglossa angularis angularis

Atheta capsularis

Atheta picipennis

Lypoglossa angularis angularis

Atheta nescia

Atheta nescia

Trypodendron lineatum

Trypodendron lineatum

Atheta klagesi

Atheta nescia

Dorytomus leucophyllus

Atheta strigosula

Trypodendron lineatum

Trypodendron lineatum

Trypodendron lineatum

Trypodendron lineatum

Thanatus formicinus

Thanatus formicinus

Corticarina minuta

Atheta frosti

Atheta capsularis

Atheta strigosula

Atheta keeni

Atheta dadopora

Tetrix ornata

Atheta curvipennis

Aleochara bilineata

\section{BOLD sample id species}

UAMIC2083-14 Orthotylus katmai

UAMIC160-13 Pseudohylesinus tsugae

UAMIC2215-14 Pseudohylesinus tsugae

UAMIC104-13

UAMIC2903-15

UAMIC249-13

UAMIC249-13

UAMIC115-13

UAMIC941-13

UAMIC2127-14

UAMIC1733-14

UAMIC2934-15

UAMIC2159-14

UAMIC1872-14

UAMIC2947-15

UAMIC1733-14

UAMIC2607-15

UAMIC2712-15

UAMIC927-13

UAMIC2622-15

UAMIC2607-15

UAMIC1786-14

UAMIC2742-15

UAMIC2598-15

UAMIC2605-15

UAMIC2700-15

UAMIC2588-15

UAMIC2592-15

UAMIC159-13

UAMIC159-13

UAMIC2632-15

UAMIC2592-15

UAMIC240-13

UAMIC2656-15

UAMIC2240-14

UAMIC2198-14

UAMIC252-13

UAMIC252-13

UAMIC1633-13

UAMIC1633-13

UAMIC3301-15

UAMIC2617-15

UAMIC2622-15

UAMIC2639-15

UAMIC2587-15

UAMIC2580-15

UAMIC573-13

UAMIC2655-15

UAMIC2476-15
Quedius fulvicollis

Quedius fulvicollis

Hylurgops rugipennis

Hylurgops rugipennis

Quedius simulator

Sminthurinus concolor

Irbisia sericans

Tetragnatha laboriosa

Dyschirius politus politus

Irbisia sericans

Phlaeopterus lagrandeuri

Bembidion arcticum

Tetragnatha laboriosa

Atheta prudhoensis

Boreostiba websteri

Coelopa stejnegeri

Atheta capsularis

Atheta prudhoensis

Tetragnatha extensa

Lypoglossa angularis angularis

Atheta capsularis

Atheta picipennis

Lypoglossa angularis angularis

Atheta nescia

Atheta nescia

Trypodendron lineatum

Trypodendron lineatum

Atheta klagesi

Atheta nescia

Dorytomus leucophyllus

Atheta strigosula

Trypodendron lineatum

Trypodendron lineatum

Trypodendron lineatum

Trypodendron lineatum

Thanatus formicinus

Thanatus formicinus

Corticarina minuta

Atheta frosti

Atheta capsularis

Atheta strigosula

Atheta keeni

Atheta dadopora

Tetrix ornata

Atheta curvipennis

Aleochara bilineata
BOLD sample id distance

UAMIC2016-14 23.394495

UAMIC2270-14 21.559633

UAMIC2270-14 21.263481

UAMIC2881-15 20.952381

UAMIC2881-15 20.813007

UAMIC2197-14 $\quad 19.4605$

UAMIC2208-14 18.960245

UAMIC2916-15 18.333334

UAMIC942-13 18.26923

UAMIC2125-14 17.889908

UAMIC1498-13 17.737003

UAMIC2921-15 17.717207

UAMIC2127-14 17.431192

UAMIC633-13 17.431192

UAMIC2922-15 17.418034

UAMIC1741-14 17.278286

UAMIC2613-15 16.360857

UAMIC2674-15 16.360857

UAMIC928-13 16.360857

UAMIC2598-15 15.902141

UAMIC2621-15 15.596331

UAMIC1787-14 15.443425

UAMIC2688-15 15.348837

UAMIC2616-15 15.284554

UAMIC2611-15 15.007657

UAMIC2688-15 14.984709

UAMIC2648-15 14.525993

UAMIC2648-15 14.333333

UAMIC2240-14 14.220184

UAMIC2198-14 14.220184

UAMIC2571-15 14.209591

UAMIC2588-15 14.166667

UAMIC112-13 14.064916

UAMIC2577-15 13.957055

UAMIC2237-14 13.914373

UAMIC2237-14 13.914373

UAMIC2240-14 13.914373

UAMIC2198-14 13.914373

UAMIC1702-13 13.761468

UAMIC1663-13 13.761468

UAMIC3328-15 13.455658

UAMIC2570-15 13.333334

UAMIC2616-15 13.170731

UAMIC2577-15 12.996942

UAMIC2645-15 12.833333

UAMIC2641-15 12.730627

UAMIC699-13 12.450593

UAMIC2654-15 12.385322

UAMIC2509-15 12.232416 
Helophorus sp.

Dinaraea n. sp.

Venusia pearsalli

Bombus fernaldae

Eupithecia tripunctaria

Stearibia nigriceps

Oxytelus laqueatus

Atheta strigosula

Scatophila cribrata

Oxytelus laqueatus

Dictyna major

Bembidion sordidum

Bombus sylvicola

Olophrum rotundicolle

Anathix puta

Emblyna peragrata

Eris militaris

Ochlerotatus fitchii

Eudonia commortalis

Gesneria centuriella

Atheta nr. picipennis

Oxypoda frigida

Scatella obsoleta

Platycheirus ciliatus

Saldula pallipes

Dendroctonus punctatus

Epuraea terminalis

Epuraea terminalis

Culiseta impatiens

Anisosticta bitriangularis

Callicorixa alaskensis

Oxypoda frigida

Oxypoda frigida

Hydriomena renunciata

Saldula laticollis

Callicorixa alaskensis

Cicindela oregona

Cicindela oregona

Pardosa dorsuncata

Dendroctonus rufipennis

Agonum consimile

Apamea alia

Hyptiotes gertschi

Lepidophorus lineaticollis

Bembidion compressum

Eristalis hirta

Epinotia nisella

Bembidion compressum

Atheta prudhoensis

Gnaphosa parvula

Dendroctonus rufipennis

Lepidophorus lineaticollis

Philodromus rufus

Zelotes fratris

\begin{tabular}{|c|c|c|c|}
\hline UAMIC2454-14 & Helophorus sp. & UAMIC2400-14 & 12.232416 \\
\hline UAMIC2691-15 & Dinaraea n. sp. & UAMIC2727-15 & 11.926605 \\
\hline UAMIC3121-15 & Venusia pearsalli & UAMIC3137-15 & 11.926605 \\
\hline UAMIC756-13 & Bombus fernaldae & UAMIC755-13 & 10.856269 \\
\hline UAMIC3057-15 & Eupithecia tripunctaria & UAMIC3056-15 & 10.856269 \\
\hline UAMIC3032-15 & Stearibia nigriceps & UAMIC2948-15 & 10.856269 \\
\hline UAMIC2355-14 & Oxytelus laqueatus & UAMIC2873-15 & 10.685805 \\
\hline UAMIC2656-15 & Atheta strigosula & UAMIC2639-15 & 10.582822 \\
\hline UAMIC968-13 & Scatophila cribrata & UAMIC967-13 & 10.397553 \\
\hline UAMIC2872-15 & Oxytelus laqueatus & UAMIC2355-14 & 9.888357 \\
\hline UAMIC1551-13 & Dictyna major & UAMIC1543-13 & 9.633028 \\
\hline UAMIC049-12 & Bembidion sordidum & UAMIC375-13 & 9.313725 \\
\hline UAMIC757-13 & Bombus sylvicola & UAMIC758-13 & 9.233449 \\
\hline UAMIC1853-14 & Olophrum rotundicolle & UAMIC1828-14 & 8.899676 \\
\hline UAMIC3157-15 & Anathix puta & UAMIC3124-15 & 8.868502 \\
\hline UAMIC1544-13 & Emblyna peragrata & UAMIC1585-13 & 8.868502 \\
\hline UAMIC1690-13 & Eris militaris & UAMIC1676-13 & 8.103975 \\
\hline UAMIC872-13 & Ochlerotatus fitchii & UAMIC873-13 & 8.103975 \\
\hline UAMIC3091-15 & Eudonia commortalis & UAMIC3092-15 & 7.9510703 \\
\hline UAMIC3145-15 & Gesneria centuriella & UAMIC3142-15 & 7.8003125 \\
\hline UAMIC2657-15 & Atheta nr. picipennis & UAMIC2626-15 & 7.7981653 \\
\hline UAMIC2784-15 & Oxypoda frigida & UAMIC2846-15 & 7.037037 \\
\hline UAMIC1011-13 & Scatella obsoleta & UAMIC1008-13 & 7.017544 \\
\hline UAMIC2968-15 & Platycheirus ciliatus & UAMIC3036-15 & 6.880734 \\
\hline UAMIC2102-14 & Saldula pallipes & UAMIC2146-14 & 6.880734 \\
\hline UAMIC2193-14 & Dendroctonus punctatus & UAMIC2204-14 & 6.6086955 \\
\hline UAMIC214-13 & Epuraea terminalis & UAMIC215-13 & 6.1191626 \\
\hline UAMIC293-13 & Epuraea terminalis & UAMIC215-13 & 5.929487 \\
\hline UAMIC908-13 & Culiseta impatiens & UAMIC907-13 & 5.819296 \\
\hline UAMIC116-13 & Anisosticta bitriangularis & UAMIC357-13 & 5.607476 \\
\hline UAMIC2152-14 & Callicorixa alaskensis & UAMIC2180-14 & 5.4226475 \\
\hline UAMIC2784-15 & Oxypoda frigida & UAMIC2812-15 & 5.400982 \\
\hline UAMIC2846-15 & Oxypoda frigida & UAMIC2812-15 & 5.3703704 \\
\hline UAMIC3136-15 & Hydriomena renunciata & UAMIC1156-13 & 5.351682 \\
\hline UAMIC2117-14 & Saldula laticollis & UAMIC2179-14 & 5.351682 \\
\hline UAMIC2118-14 & Callicorixa alaskensis & UAMIC2152-14 & 5.103668 \\
\hline UAMIC358-13 & Cicindela oregona & UAMIC289-13 & 5.0161815 \\
\hline UAMIC018-12 & Cicindela oregona & UAMIC358-13 & 5.0161815 \\
\hline UAMIC1430-13 & Pardosa dorsuncata & UAMIC1501-13 & 5.0161815 \\
\hline UAMIC260-13 & Dendroctonus rufipennis & UAMIC169-13 & 4.8929667 \\
\hline UAMIC073-12 & Agonum consimile & UAMIC301-13 & 4.6666665 \\
\hline UAMIC3177-15 & Apamea alia & UAMIC3186-15 & 4.587156 \\
\hline UAMIC1296-13 & Hyptiotes gertschi & UAMIC1297-13 & 4.587156 \\
\hline UAMIC415-13 & Lepidophorus lineaticollis & UAMIC1851-14 & 4.434251 \\
\hline UAMIC3409-15 & Bembidion compressum & UAMIC3417-15 & 4.2483664 \\
\hline UAMIC2979-15 & Eristalis hirta & UAMIC3025-15 & 4.134763 \\
\hline UAMIC3109-15 & Epinotia nisella & UAMIC3110-15 & 4.1284404 \\
\hline UAMIC3409-15 & Bembidion compressum & UAMIC3414-15 & 3.9800994 \\
\hline UAMIC2621-15 & Atheta prudhoensis & UAMIC2613-15 & 3.82263 \\
\hline UAMIC1597-13 & Gnaphosa parvula & UAMIC1547-13 & 3.6753445 \\
\hline UAMIC2278-14 & Dendroctonus rufipennis & UAMIC169-13 & 3.6697247 \\
\hline UAMIC211-13 & Lepidophorus lineaticollis & UAMIC1851-14 & 3.6697247 \\
\hline UAMIC1648-13 & Philodromus rufus & UAMIC1629-13 & 3.6697247 \\
\hline UAMIC1593-13 & Zelotes fratris & UAMIC1527-13 & 3.5658915 \\
\hline
\end{tabular}


Dendroctonus rufipennis Trypodendron lineatum Trypodendron lineatum Gabrius brevipennis Compsobata pallipes Dendroctonus rufipennis Eana argentana Dendroctonus rufipennis Bombus sitkensis Dendroctonus rufipennis Chrysotus n. sp. choricus grp Xanthorhoe fossaria Bromius obscurus Clubiona furcata Mecomma gilvipes Compsobata pallipes Aspitates forbesi Colias nastes Pardosa fuscula Dendroctonus rufipennis Xanthorhoe abrasaria Xysticus triguttatus Dasysyrphus amalopis Dictyna arundinacea Colias hecla Apotomis tertiana Apotomis tertiana Gnathacmaeops pratensis Gnathacmaeops pratensis Pteromicra pectorosa Dolichopus detersus Helophora insignis Incisalia augustinus Lithomoia germana Upis ceramboides Xestia alaskae Dropephylla longula Oedothorax alascensis Oedothorax alascensis Pardosa hyperborea Atrecus macrocephalus Volucella bombylans Plectrura spinicauda Colias tyche Planolinus tenellus Agyneta manni Lygus rugulipennis Pardosa albomaculata Planolinus tenellus Dolichopus rupestris Agrilus politus Dermestes lardarius Hippodamia parenthesis Plectrura spinicauda

\begin{tabular}{|c|c|c|c|}
\hline UAMIC2232-14 & Dendroctonus rufipennis & UAMIC169-13 & 3.5168197 \\
\hline UAMIC159-13 & Trypodendron lineatum & UAMIC2237-14 & 3.5168197 \\
\hline UAMIC252-13 & Trypodendron lineatum & UAMIC159-13 & 3.5168197 \\
\hline UAMIC121-13 & Gabrius brevipennis & UAMIC2919-15 & 3.4482758 \\
\hline UAMIC3007-15 & Compsobata pallipes & UAMIC2988-15 & 3.3639145 \\
\hline UAMIC260-13 & Dendroctonus rufipennis & UAMIC2278-14 & 3.3639145 \\
\hline UAMIC468-13 & Eana argentana & UAMIC467-13 & 3.3639145 \\
\hline UAMIC2206-14 & Dendroctonus rufipennis & UAMIC169-13 & 3.3175356 \\
\hline UAMIC713-13 & Bombus sitkensis & UAMIC688-13 & 3.2312925 \\
\hline UAMIC260-13 & Dendroctonus rufipennis & UAMIC2206-14 & 3.1595576 \\
\hline UAMIC877-13 & Chrysotus n. sp. choricus grp & UAMIC885-13 & 3.0769231 \\
\hline UAMIC515-13 & Xanthorhoe fossaria & UAMIC514-13 & 3.0595813 \\
\hline UAMIC2275-14 & Bromius obscurus & UAMIC2267-14 & 3.058104 \\
\hline UAMIC1532-13 & Clubiona furcata & UAMIC1541-13 & 3.058104 \\
\hline UAMIC2053-14 & Mecomma gilvipes & UAMIC2074-14 & 3.058104 \\
\hline UAMIC3033-15 & Compsobata pallipes & UAMIC3007-15 & 3.030303 \\
\hline UAMIC3195-15 & Aspitates forbesi & UAMIC3194-15 & 2.973396 \\
\hline UAMIC436-13 & Colias nastes & UAMIC3202-15 & 2.9411764 \\
\hline UAMIC1500-13 & Pardosa fuscula & UAMIC1456-13 & 2.9411764 \\
\hline UAMIC260-13 & Dendroctonus rufipennis & UAMIC2232-14 & 2.9051988 \\
\hline UAMIC569-13 & Xanthorhoe abrasaria & UAMIC568-13 & 2.7642276 \\
\hline UAMIC1716-14 & Xysticus triguttatus & UAMIC1724-14 & 2.672956 \\
\hline UAMIC2977-15 & Dasysyrphus amalopis & UAMIC2958-15 & 2.5993884 \\
\hline UAMIC1584-13 & Dictyna arundinacea & UAMIC1545-13 & 2.5993884 \\
\hline UAMIC435-13 & Colias hecla & UAMIC3257-15 & 2.578269 \\
\hline UAMIC3150-15 & Apotomis tertiana & UAMIC3151-15 & 2.4464834 \\
\hline UAMIC3150-15 & Apotomis tertiana & UAMIC3143-15 & 2.4464834 \\
\hline UAMIC2398-14 & Gnathacmaeops pratensis & UAMIC2403-14 & 2.4464834 \\
\hline UAMIC2398-14 & Gnathacmaeops pratensis & UAMIC2433-14 & 2.4464834 \\
\hline UAMIC3315-15 & Pteromicra pectorosa & UAMIC3310-15 & 2.4038463 \\
\hline UAMIC898-13 & Dolichopus detersus & UAMIC897-13 & 2.293578 \\
\hline UAMIC1250-13 & Helophora insignis & UAMIC1309-13 & 2.293578 \\
\hline UAMIC3206-15 & Incisalia augustinus & UAMIC3256-15 & 2.293578 \\
\hline UAMIC3155-15 & Lithomoia germana & UAMIC3161-15 & 2.1406727 \\
\hline UAMIC221-13 & Upis ceramboides & UAMIC355-13 & 2.1406727 \\
\hline UAMIC3345-15 & Xestia alaskae & UAMIC482-13 & 2.1406727 \\
\hline UAMIC2298-14 & Dropephylla longula & UAMIC2345-14 & 2 \\
\hline UAMIC1318-13 & Oedothorax alascensis & UAMIC1631-13 & 1.9877676 \\
\hline UAMIC1318-13 & Oedothorax alascensis & UAMIC1319-13 & 1.9877676 \\
\hline UAMIC1458-13 & Pardosa hyperborea & UAMIC1481-13 & 1.9323671 \\
\hline UAMIC135-13 & Atrecus macrocephalus & UAMIC2890-15 & 1.923077 \\
\hline UAMIC3367-15 & Volucella bombylans & UAMIC3366-15 & 1.8867924 \\
\hline UAMIC168-13 & Plectrura spinicauda & UAMIC2246-14 & 1.860465 \\
\hline UAMIC446-13 & Colias tyche & UAMIC443-13 & 1.843318 \\
\hline UAMIC2562-15 & Planolinus tenellus & UAMIC2563-15 & 1.8376722 \\
\hline UAMIC1672-13 & Agyneta manni & UAMIC1688-13 & 1.8348624 \\
\hline UAMIC2079-14 & Lygus rugulipennis & UAMIC2034-14 & 1.8348624 \\
\hline UAMIC1453-13 & Pardosa albomaculata & UAMIC1455-13 & 1.8348624 \\
\hline UAMIC2563-15 & Planolinus tenellus & UAMIC2564-15 & 1.8348624 \\
\hline UAMIC859-13 & Dolichopus rupestris & UAMIC858-13 & 1.8036073 \\
\hline UAMIC447-13 & Agrilus politus & UAMIC212-13 & 1.7214397 \\
\hline UAMIC139-13 & Dermestes lardarius & UAMIC2882-15 & 1.7054263 \\
\hline UAMIC332-13 & Hippodamia parenthesis & UAMIC204-13 & 1.6975307 \\
\hline UAMIC168-13 & Plectrura spinicauda & UAMIC254-13 & 1.6845329 \\
\hline
\end{tabular}


Hadrotes crassus

Lepidophorus lineaticollis

Ligyrocoris sylvestris

Nephrotoma ferruginea

Steremnius carinatus

Hylurgops rugipennis

Pseudohylesinus tsugae

Plectrura spinicauda

Olophrum consimile

Olophrum consimile

Pardosa dorsuncata

Dysstroma hersiliata

Erebia pawloskii

Atrecus macrocephalus

Plectrura spinicauda

Allomengea scopigera

Dendroctonus rufipennis

Diacheila polita

Gnaphosa borea

Hadrotes crassus

Loricera pilicornis

Nebria nivalis

Olophrum consimile

Olophrum consimile

Olophrum consimile

Olophrum consimile

Olophrum consimile

Olophrum consimile

Pardosa groenlandica

Pardosa groenlandica

Prothalpia holmbergi

Dolichopus longicornis

Pterostichus brevicornis

Boloria chariclea

Boloria chariclea

Euxoa campestris

Boloria chariclea

Boloria chariclea

Dendroctonus rufipennis

Olophrum latum

Euxoa campestris

Plectrura spinicauda

Lioon simplicipes

Acidota quadrata

Acidota quadrata

Botanophila rubrigena

Cyclosa conica

Cyclosa conica

Dicerca tenebrica

Dicerca tenebrica

Evarcha proszynskii

Geocoris howardi

Larinioides cornutus

Leptobunus borealis

\begin{tabular}{|c|c|c|c|}
\hline UAMIC2868-15 & Hadrotes crassus & UAMIC1074-13 & 1.6819572 \\
\hline UAMIC211-13 & Lepidophorus lineaticollis & UAMIC415-13 & 1.6819572 \\
\hline UAMIC1947-14 & Ligyrocoris sylvestris & UAMIC1909-14 & 1.6819572 \\
\hline UAMIC1112-13 & Nephrotoma ferruginea & UAMIC1113-13 & 1.6819572 \\
\hline UAMIC151-13 & Steremnius carinatus & UAMIC248-13 & 1.6819572 \\
\hline UAMIC2197-14 & Hylurgops rugipennis & UAMIC2208-14 & 1.5414258 \\
\hline UAMIC160-13 & Pseudohylesinus tsugae & UAMIC2215-14 & 1.540832 \\
\hline UAMIC168-13 & Plectrura spinicauda & UAMIC2259-14 & 1.5313935 \\
\hline UAMIC1840-14 & Olophrum consimile & UAMIC1902-14 & 1.529052 \\
\hline UAMIC1840-14 & Olophrum consimile & UAMIC1892-14 & 1.529052 \\
\hline UAMIC1514-13 & Pardosa dorsuncata & UAMIC1430-13 & 1.4563107 \\
\hline UAMIC3108-15 & Dysstroma hersiliata & UAMIC3147-15 & 1.4285715 \\
\hline UAMIC3227-15 & Erebia pawloskii & UAMIC3242-15 & 1.4150944 \\
\hline UAMIC432-13 & Atrecus macrocephalus & UAMIC2890-15 & 1.4109347 \\
\hline UAMIC254-13 & Plectrura spinicauda & UAMIC2246-14 & 1.3953488 \\
\hline UAMIC1618-13 & Allomengea scopigera & UAMIC1620-13 & 1.3761468 \\
\hline UAMIC2232-14 & Dendroctonus rufipennis & UAMIC2278-14 & 1.3761468 \\
\hline UAMIC1837-14 & Diacheila polita & UAMIC1816-14 & 1.3761468 \\
\hline UAMIC1586-13 & Gnaphosa borea & UAMIC1595-13 & 1.3761468 \\
\hline UAMIC2878-15 & Hadrotes crassus & UAMIC2868-15 & 1.3761468 \\
\hline UAMIC288-13 & Loricera pilicornis & UAMIC014-12 & 1.3761468 \\
\hline UAMIC080-12 & Nebria nivalis & UAMIC298-13 & 1.3761468 \\
\hline UAMIC1902-14 & Olophrum consimile & UAMIC1870-14 & 1.3761468 \\
\hline UAMIC1892-14 & Olophrum consimile & UAMIC1822-14 & 1.3761468 \\
\hline UAMIC1892-14 & Olophrum consimile & UAMIC1902-14 & 1.3761468 \\
\hline UAMIC1840-14 & Olophrum consimile & UAMIC1822-14 & 1.3761468 \\
\hline UAMIC1817-14 & Olophrum consimile & UAMIC1892-14 & 1.3761468 \\
\hline UAMIC1817-14 & Olophrum consimile & UAMIC1840-14 & 1.3761468 \\
\hline UAMIC1463-13 & Pardosa groenlandica & UAMIC1450-13 & 1.3761468 \\
\hline UAMIC1510-13 & Pardosa groenlandica & UAMIC1450-13 & 1.3761468 \\
\hline UAMIC263-13 & Prothalpia holmbergi & UAMIC171-13 & 1.3761468 \\
\hline UAMIC891-13 & Dolichopus longicornis & UAMIC887-13 & 1.3400335 \\
\hline UAMIC010-12 & Pterostichus brevicornis & UAMIC364-13 & 1.2944984 \\
\hline UAMIC3204-15 & Boloria chariclea & UAMIC487-13 & 1.2820513 \\
\hline UAMIC3246-15 & Boloria chariclea & UAMIC487-13 & 1.2820513 \\
\hline UAMIC519-13 & Euxoa campestris & UAMIC3070-15 & 1.275917 \\
\hline UAMIC3204-15 & Boloria chariclea & UAMIC488-13 & 1.2698413 \\
\hline UAMIC3246-15 & Boloria chariclea & UAMIC488-13 & 1.2698413 \\
\hline UAMIC2232-14 & Dendroctonus rufipennis & UAMIC2206-14 & 1.263823 \\
\hline UAMIC108-13 & Olophrum latum & UAMIC1829-14 & 1.263823 \\
\hline UAMIC518-13 & Euxoa campestris & UAMIC3070-15 & 1.2519562 \\
\hline UAMIC2259-14 & Plectrura spinicauda & UAMIC2246-14 & 1.2403101 \\
\hline UAMIC1107-13 & Lioon simplicipes & UAMIC1101-13 & 1.2288786 \\
\hline UAMIC2496-15 & Acidota quadrata & UAMIC2508-15 & 1.2232417 \\
\hline UAMIC2496-15 & Acidota quadrata & UAMIC2532-15 & 1.2232417 \\
\hline UAMIC1035-13 & Botanophila rubrigena & UAMIC1036-13 & 1.2232417 \\
\hline UAMIC1496-13 & Cyclosa conica & UAMIC1522-13 & 1.2232417 \\
\hline UAMIC1489-13 & Cyclosa conica & UAMIC1496-13 & 1.2232417 \\
\hline UAMIC2389-14 & Dicerca tenebrica & UAMIC2395-14 & 1.2232417 \\
\hline UAMIC2463-14 & Dicerca tenebrica & UAMIC2389-14 & 1.2232417 \\
\hline UAMIC1641-13 & Evarcha proszynskii & UAMIC1758-14 & 1.2232417 \\
\hline UAMIC1991-14 & Geocoris howardi & UAMIC1941-14 & 1.2232417 \\
\hline UAMIC1440-13 & Larinioides cornutus & UAMIC1495-13 & 1.2232417 \\
\hline UAMIC1796-14 & Leptobunus borealis & UAMIC1731-14 & 1.2232417 \\
\hline
\end{tabular}




\begin{tabular}{|c|c|c|c|c|}
\hline Monochamus scutellatus & UAMIC224-13 & Monochamus scutellatus & UAMIC429-13 & 1.2232417 \\
\hline Olophrum consimile & UAMIC1817-14 & Olophrum consimile & UAMIC1870-14 & 1.2232417 \\
\hline Dendrophagus cygnaei & UAMIC167-13 & Dendrophagus cygnaei & UAMIC225-13 & 1.1647254 \\
\hline Xanthorhoe decoloraria & UAMIC566-13 & Xanthorhoe decoloraria & UAMIC567-13 & 1.132686 \\
\hline Acidota quadrata & UAMIC1818-14 & Acidota quadrata & UAMIC2508-15 & 1.1272142 \\
\hline Acidota quadrata & UAMIC1818-14 & Acidota quadrata & UAMIC2532-15 & 1.1272142 \\
\hline Agroeca ornata & UAMIC1607-13 & Agroeca ornata & UAMIC1530-13 & 1.1164274 \\
\hline Alypia langtoni & UAMIC645-13 & Alypia langtoni & UAMIC3193-15 & 1.0703363 \\
\hline Anthocoris musculus & UAMIC2036-14 & Anthocoris musculus & UAMIC599-13 & 1.0703363 \\
\hline Carabus truncaticollis & UAMIC1901-14 & Carabus truncaticollis & UAMIC331-13 & 1.0703363 \\
\hline Clubiona riparia & UAMIC1574-13 & Clubiona riparia & UAMIC1524-13 & 1.0703363 \\
\hline Dolichopus stenhammari & UAMIC876-13 & Dolichopus stenhammari & UAMIC864-13 & 1.0703363 \\
\hline Dryocoetes affaber & UAMIC2277-14 & Dryocoetes affaber & UAMIC278-13 & 1.0703363 \\
\hline Geocoris howardi & UAMIC1913-14 & Geocoris howardi & UAMIC1941-14 & 1.0703363 \\
\hline Micaria aenea & UAMIC1587-13 & Micaria aenea & UAMIC1580-13 & 1.0703363 \\
\hline Ochlerotatus excrucians & UAMIC913-13 & Ochlerotatus excrucians & UAMIC912-13 & 1.0703363 \\
\hline Olophrum consimile & UAMIC1902-14 & Olophrum consimile & UAMIC1822-14 & 1.0703363 \\
\hline Olophrum consimile & UAMIC1840-14 & Olophrum consimile & UAMIC1870-14 & 1.0703363 \\
\hline Priognathus monilicornis & UAMIC257-13 & Priognathus monilicornis & UAMIC238-13 & 1.0703363 \\
\hline Sthereus ptinoides & UAMIC220-13 & Sthereus ptinoides & UAMIC1896-14 & 1.0703363 \\
\hline Sthereus ptinoides & UAMIC220-13 & Sthereus ptinoides & UAMIC427-13 & 1.0703363 \\
\hline Tetanocera robusta & UAMIC3269-15 & Tetanocera robusta & UAMIC1021-13 & 1.0703363 \\
\hline Thanatophilus sagax & UAMIC130-13 & Thanatophilus sagax & UAMIC1087-13 & 1.0703363 \\
\hline Gonatium crassipalpum & UAMIC1282-13 & Gonatium crassipalpum & UAMIC1275-13 & 0.990099 \\
\hline Stictopleurus punctiventris & UAMIC1944-14 & Stictopleurus punctiventris & UAMIC1959-14 & 0.9852217 \\
\hline Araneus trifolium & UAMIC1474-13 & Araneus trifolium & UAMIC1473-13 & 0.9803922 \\
\hline Araneus trifolium & UAMIC1474-13 & Araneus trifolium & UAMIC1460-13 & 0.9803922 \\
\hline Evarcha proszynskii & UAMIC1641-13 & Evarcha proszynskii & UAMIC1751-14 & 0.9803922 \\
\hline Agonum nigriceps & UAMIC365-13 & Agonum nigriceps & UAMIC054-12 & 0.9771987 \\
\hline Hydriomena furcata & UAMIC543-13 & Hydriomena furcata & UAMIC542-13 & 0.9661835 \\
\hline Amara patruelis & UAMIC2418-14 & Amara patruelis & UAMIC2420-14 & 0.9584664 \\
\hline Hippodamia convergens & UAMIC2429-14 & Hippodamia convergens & UAMIC2468-14 & 0.9389672 \\
\hline Aegialia criddlei & UAMIC2502-15 & Aegialia criddlei & UAMIC2499-15 & 0.9174312 \\
\hline Aegialia criddlei & UAMIC2492-15 & Aegialia criddlei & UAMIC2499-15 & 0.9174312 \\
\hline Agyneta perspicua & UAMIC1636-13 & Agyneta perspicua & UAMIC1685-13 & 0.9174312 \\
\hline Amara patruelis & UAMIC1838-14 & Amara patruelis & UAMIC2420-14 & 0.9174312 \\
\hline Canalidion montanum & UAMIC1231-13 & Canalidion montanum & UAMIC1207-13 & 0.9174312 \\
\hline Cephaloon bicolor & UAMIC176-13 & Cephaloon bicolor & UAMIC271-13 & 0.9174312 \\
\hline Chlamydatus keltoni & UAMIC2131-14 & Chlamydatus keltoni & UAMIC2110-14 & 0.9174312 \\
\hline Collinsia holmgreni & UAMIC1287-13 & Collinsia holmgreni & UAMIC1667-13 & 0.9174312 \\
\hline Collinsia ksenia & UAMIC1292-13 & Collinsia ksenia & UAMIC1301-13 & 0.9174312 \\
\hline Dryocoetes affaber & UAMIC2277-14 & Dryocoetes affaber & UAMIC170-13 & 0.9174312 \\
\hline Euxoa comosa & UAMIC3077-15 & Euxoa comosa & UAMIC3103-15 & 0.9174312 \\
\hline Hippodamia convergens & UAMIC2429-14 & Hippodamia convergens & UAMIC2452-14 & 0.9174312 \\
\hline Olophrum consimile & UAMIC1817-14 & Olophrum consimile & UAMIC1822-14 & 0.9174312 \\
\hline Pityohyphantes cristatus & UAMIC1315-13 & Pityohyphantes cristatus & UAMIC1242-13 & 0.9174312 \\
\hline Pterostichus pinguedineus & UAMIC065-12 & Pterostichus pinguedineus & UAMIC012-12 & 0.9174312 \\
\hline Walckenaeria cornuella & UAMIC1691-13 & Walckenaeria cornuella & UAMIC1669-13 & 0.9174312 \\
\hline Xysticus durus & UAMIC1794-14 & Xysticus durus & UAMIC1722-14 & 0.9174312 \\
\hline Pterostichus amethystinus & UAMIC089-12 & Pterostichus amethystinus & UAMIC360-13 & 0.8865249 \\
\hline Phloeonomus suffusus & UAMIC637-13 & Phloeonomus suffusus & UAMIC631-13 & 0.8635579 \\
\hline Eutrichapion viciae & UAMIC124-13 & Eutrichapion viciae & UAMIC416-13 & 0.8403362 \\
\hline Caelius montana & UAMIC2497-15 & Caelius montana & UAMIC2495-15 & 0.8090615 \\
\hline Caelius montana & UAMIC2501-15 & Caelius montana & UAMIC2497-15 & 0.8090615 \\
\hline
\end{tabular}


Bembidion planatum

Elgiva solicita

Amara patruelis

Amara patruelis

Anthocoris musculus

Chrysobothris trinervia

Carabus truncaticollis

Chlamydatus keltoni

Pelegrina montana

Agnyphantes arboreus

Amara patruelis

Amara patruelis

Antherophagus suturalis

Chrysomela crotchi

Dicyrtoma maculosa

Eupithecia niphadophilata

Liparocephalus cordicollis

Misumena vatia

Neoantistea magna

Olophrum consimile

Philodromus pernix

Suillia convergens

Tetragnatha laboriosa

Tipula platymera

Xestoleptura behrensii

Xysticus britcheri

Xysticus ellipticus

Pteromicra angustipennis

Trichodezia albovittata

Micaria pulicaria

Elgiva solicita

Amara patruelis

Xysticus chippewa

Corticaria serrata

Amara patruelis

Acidota quadrata

Aeshna interrupta

Aleochara castaneipennis

Amara alpina

Amara alpina

Anthomyia mimetica

Araneus nordmanni

Araneus trifolium

Araneus trifolium

Bathyphantes pallidus

Bembidion kuprianovii

Caenis youngi

Chrysops excitans

Eupeodes luniger

Hypogastrura helena

Judolia montivagans

Libellula quadrimaculata

Liparocephalus brevipennis

Notiophilus sylvaticus

\begin{tabular}{|c|c|c|c|}
\hline UAMIC003-12 & Bembidion planatum & UAMIC373-13 & 0.805153 \\
\hline UAMIC3419-15 & Elgiva solicita & UAMIC3286-15 & 0.8038585 \\
\hline UAMIC2418-14 & Amara patruelis & UAMIC1809-14 & 0.7987221 \\
\hline UAMIC2418-14 & Amara patruelis & UAMIC2390-14 & 0.7987221 \\
\hline UAMIC2069-14 & Anthocoris musculus & UAMIC2036-14 & 0.7974481 \\
\hline UAMIC391-13 & Chrysobothris trinervia & UAMIC191-13 & 0.7751938 \\
\hline UAMIC027-12 & Carabus truncaticollis & UAMIC1901-14 & 0.770416 \\
\hline UAMIC2116-14 & Chlamydatus keltoni & UAMIC2110-14 & 0.7668712 \\
\hline UAMIC1725-14 & Pelegrina montana & UAMIC1755-14 & 0.7656968 \\
\hline UAMIC1267-13 & Agnyphantes arboreus & UAMIC1680-13 & 0.764526 \\
\hline UAMIC1838-14 & Amara patruelis & UAMIC1809-14 & 0.764526 \\
\hline UAMIC1838-14 & Amara patruelis & UAMIC2390-14 & 0.764526 \\
\hline UAMIC2507-15 & Antherophagus suturalis & UAMIC2491-15 & 0.764526 \\
\hline UAMIC3388-15 & Chrysomela crotchi & UAMIC3389-15 & 0.764526 \\
\hline UAMIC944-13 & Dicyrtoma maculosa & UAMIC943-13 & 0.764526 \\
\hline UAMIC3087-15 & Eupithecia niphadophilata & UAMIC3079-15 & 0.764526 \\
\hline UAMIC424-13 & Liparocephalus cordicollis & UAMIC131-13 & 0.764526 \\
\hline UAMIC1781-14 & Misumena vatia & UAMIC1753-14 & 0.764526 \\
\hline UAMIC1542-13 & Neoantistea magna & UAMIC1556-13 & 0.764526 \\
\hline UAMIC1817-14 & Olophrum consimile & UAMIC1902-14 & 0.764526 \\
\hline UAMIC1623-13 & Philodromus pernix & UAMIC1578-13 & 0.764526 \\
\hline UAMIC3283-15 & Suillia convergens & UAMIC3282-15 & 0.764526 \\
\hline UAMIC1498-13 & Tetragnatha laboriosa & UAMIC1741-14 & 0.764526 \\
\hline UAMIC1111-13 & Tipula platymera & UAMIC1110-13 & 0.764526 \\
\hline UAMIC1092-13 & Xestoleptura behrensii & UAMIC2242-14 & 0.764526 \\
\hline UAMIC1773-14 & Xysticus br & UAMIC1788-14 & 0.764526 \\
\hline UAMIC1729-14 & Xysticus ellipticus & UAMIC1750-14 & 0.764526 \\
\hline UAMIC3268-15 & Pteromicra angustipennis & UAMIC3285-15 & 0.6568145 \\
\hline UAMIC498-13 & Trichodezia albovittata & UAMIC565-13 & 0.6535948 \\
\hline UAMIC1538-13 & Micaria pulicaria & UAMIC1557-13 & 0.6504065 \\
\hline UAMIC3286-15 & Elgiva solicita & UAMIC3287-15 & 0.6410257 \\
\hline UAMIC2418-14 & Amara patruelis & UAMIC2449-14 & 0.64 \\
\hline UAMIC1752-14 & Xysticus chippewa & UAMIC1776-14 & 0.620155 \\
\hline UAMIC3413-15 & Corticaria serrata & UAMIC3411-15 & 0.6134969 \\
\hline UAMIC1838-14 & Amara patruelis & UAMIC2449-14 & 0.6125575 \\
\hline UAMIC2532-15 & Acidota quadrata & UAMIC2508-15 & 0.6116208 \\
\hline UAMIC775-13 & Aeshna interrupta & UAMIC776-13 & 0.6116208 \\
\hline UAMIC2542-15 & Aleochara castaneipennis & UAMIC2559-15 & 0.6116208 \\
\hline UAMIC1850-14 & Amara alpina & UAMIC007-12 & 0.6116208 \\
\hline UAMIC1898-14 & Amara alpina & UAMIC007-12 & 0.6116208 \\
\hline UAMIC1030-13 & Anthomyia mimetica & UAMIC1029-13 & 0.6116208 \\
\hline UAMIC1434-13 & Araneus nordmanni & UAMIC1468-13 & 0.6116208 \\
\hline UAMIC1465-13 & Araneus trifolium & UAMIC1473-13 & 0.6116208 \\
\hline UAMIC1460-13 & Araneus trifolium & UAMIC1465-13 & 0.6116208 \\
\hline UAMIC1670-13 & Bathyphantes pallidus & UAMIC1687-13 & 0.6116208 \\
\hline UAMIC3408-15 & Bembidion kuprianovii & UAMIC040-12 & 0.6116208 \\
\hline UAMIC931-13 & Caenis youngi & UAMIC930-13 & 0.6116208 \\
\hline UAMIC958-13 & Chrysops excitans & UAMIC956-13 & 0.6116208 \\
\hline UAMIC3015-15 & Eupeodes luniger & UAMIC3040-15 & 0.6116208 \\
\hline UAMIC951-13 & Hypogastrura helena & UAMIC952-13 & 0.6116208 \\
\hline UAMIC2387-14 & Judolia montivagans & UAMIC2471-14 & 0.6116208 \\
\hline UAMIC767-13 & Libellula quadrimaculata & UAMIC823-13 & 0.6116208 \\
\hline UAMIC2748-15 & Liparocephalus brevipennis & UAMIC2679-15 & 0.6116208 \\
\hline UAMIC340-13 & Notiophilus sylvaticus & UAMIC020-12 & 0.611620 \\
\hline
\end{tabular}


Philodromus praelustris Phlaeopterus cavicollis Plagiognathus brunneus Suillia convergens Tibellus maritimus Lioligus nitidus Campaea perlata Thaumatomyia annulata Javesella pellucida Quedius pullmani Parnassius phoebus Cuerna striata Cuerna striata Stictopleurus punctiventris Tachinus apterus Pardosa palustris Mniusa yukonensis Plateumaris sp. Xysticus obscurus Elgiva solicita Hackmania prominula Pterostichus nivalis Bembidion compressum Polygraphus rufipennis Plateumaris sp.

Adalia bipunctata Adalia bipunctata Aleochara castaneipennis Araneus nordmanni Callobius pictus Cynomya mortuorum Dicheirotrichus cognatus Dolichopus plumipes Dryocoetes affaber Enoplognatha intrepida Gonioctena notmani Gonioctena notmani Hypsosinga pygmaea Irbisia sericans Larinioides patagiatus Larinioides patagiatus Lucilia illustris

Melangyna arctica Melanoplus fasciatus Mniusa yukonensis Nebria metallica Opisthius richardsoni Parnassius phoebus Scaphinotus marginatus Sphaerophoria philanthus Stictopleurus punctiventris Tunagyna debilis Xysticus montanensis Bembidion coloradense

\begin{tabular}{|c|c|c|c|}
\hline UAMIC1678-13 & Philodromus praelustris & UAMIC1635-13 & 0.6116208 \\
\hline UAMIC2290-14 & Phlaeopterus cavicollis & UAMIC2305-14 & 0.6116208 \\
\hline UAMIC2072-14 & Plagiognathus brunneus & UAMIC2037-14 & 0.6116208 \\
\hline UAMIC3283-15 & Suillia convergens & UAMIC3284-15 & 0.6116208 \\
\hline UAMIC1656-13 & Tibellus maritimus & UAMIC1659-13 & 0.6116208 \\
\hline UAMIC1117-13 & Lioligus nitidus & UAMIC1100-13 & 0.6 \\
\hline UAMIC539-13 & Campaea perlata & UAMIC538-13 & 0.5235602 \\
\hline UAMIC895-13 & Thaumatomyia annulata & UAMIC894-13 & 0.5025126 \\
\hline UAMIC1967-14 & Javesella pellucida & UAMIC584-13 & 0.4975124 \\
\hline UAMIC1105-13 & Quedius pullmani & UAMIC1127-13 & 0.4975124 \\
\hline UAMIC438-13 & Parnassius phoebus & UAMIC3228-15 & 0.4950495 \\
\hline UAMIC1980-14 & Cuerna striata & UAMIC1983-14 & 0.4926108 \\
\hline UAMIC1980-14 & Cuerna striata & UAMIC1921-14 & 0.4926108 \\
\hline UAMIC1944-14 & Stictopleurus punctiventris & UAMIC1971-14 & 0.4926108 \\
\hline UAMIC1866-14 & Tachinus apterus & UAMIC1899-14 & 0.4926108 \\
\hline UAMIC1435-13 & Pardosa palustris & UAMIC1451-13 & 0.4901961 \\
\hline UAMIC2689-15 & Mniusa yukonensis & UAMIC2690-15 & 0.4885993 \\
\hline UAMIC2227-14 & Plateumaris sp. & UAMIC2276-14 & 0.4878049 \\
\hline UAMIC1742-14 & Xysticus obscurus & UAMIC1782-14 & 0.4830918 \\
\hline UAMIC3419-15 & Elgiva solicita & UAMIC3287-15 & 0.4823151 \\
\hline UAMIC1575-13 & Hackmania prominula & UAMIC1583-13 & 0.4761905 \\
\hline UAMIC1888-14 & Pterostichus nivalis & UAMIC1886-14 & 0.4761905 \\
\hline UAMIC3417-15 & Bembidion compressum & UAMIC3414-15 & 0.4672897 \\
\hline UAMIC2201-14 & Polygraphus rufipennis & UAMIC2264-14 & 0.4651163 \\
\hline UAMIC2276-14 & Plateumaris sp. & UAMIC2192-14 & 0.4608295 \\
\hline UAMIC2430-14 & Adalia bipunctata & UAMIC2431-14 & 0.4587156 \\
\hline UAMIC2384-14 & Adalia bipunctata & UAMIC2431-14 & 0.4587156 \\
\hline UAMIC2545-15 & Aleochara castaneipennis & UAMIC2559-15 & 0.4587156 \\
\hline UAMIC1434-13 & Araneus nordmanni & UAMIC1513-13 & 0.4587156 \\
\hline UAMIC1568-13 & Callobius pictus & UAMIC1526-13 & 0.4587156 \\
\hline UAMIC921-13 & Cynomya mortuorum & UAMIC922-13 & 0.4587156 \\
\hline UAMIC092-12 & Dicheirotrichus cognatus & UAMIC381-13 & 0.4587156 \\
\hline UAMIC904-13 & Dolichopus plumipes & UAMIC923-13 & 0.4587156 \\
\hline UAMIC170-13 & Dryocoetes affaber & UAMIC278-13 & 0.4587156 \\
\hline UAMIC1204-13 & Enoplognatha intrepida & UAMIC1203-13 & 0.4587156 \\
\hline UAMIC2254-14 & Gonioctena notmani & UAMIC2210-14 & 0.4587156 \\
\hline UAMIC2262-14 & Gonioctena notmani & UAMIC2254-14 & 0.4587156 \\
\hline UAMIC1444-13 & Hypsosinga pygmaea & UAMIC1519-13 & 0.4587156 \\
\hline UAMIC2159-14 & Irbisia sericans & UAMIC2125-14 & 0.4587156 \\
\hline UAMIC1499-13 & Larinioides patagiatus & UAMIC1457-13 & 0.4587156 \\
\hline UAMIC1499-13 & Larinioides patagiatus & UAMIC1428-13 & 0.4587156 \\
\hline UAMIC893-13 & Lucilia illustris & UAMIC900-13 & 0.4587156 \\
\hline UAMIC2980-15 & Melangyna arctica & UAMIC2991-15 & 0.4587156 \\
\hline UAMIC585-13 & Melanoplus fasciatus & UAMIC586-13 & 0.4587156 \\
\hline UAMIC2715-15 & Mniusa yukonensis & UAMIC2690-15 & 0.4587156 \\
\hline UAMIC300-13 & Nebria metallica & UAMIC016-12 & 0.4587156 \\
\hline UAMIC001-12 & Opisthius richardsoni & UAMIC342-13 & 0.4587156 \\
\hline UAMIC439-13 & Parnassius phoebus & UAMIC3228-15 & 0.4587156 \\
\hline UAMIC019-12 & Scaphinotus marginatus & UAMIC311-13 & 0.4587156 \\
\hline UAMIC3018-15 & Sphaerophoria philanthus & UAMIC2960-15 & 0.4587156 \\
\hline UAMIC1971-14 & Stictopleurus punctiventris & UAMIC1959-14 & 0.4587156 \\
\hline UAMIC1357-13 & Tunagyna debilis & UAMIC1363-13 & 0.4587156 \\
\hline UAMIC1802-14 & Xysticus montanensis & UAMIC1748-14 & 0.4587156 \\
\hline UAMIC368-13 & Bembidion coloradense & UAMIC039-12 & 0.399201 \\
\hline
\end{tabular}


Tipula limbata

Bombus melanopygus

Araniella displicata

Philaenarcys bilineata

Philaenarcys bilineata

Plagiognathus brunneus

Bathyphantes reprobus

Boloria freija

Pteromicra angustipennis

Pristoceuthophilus cercalis

Araneus trifolium

Nabis inscriptus

Nicrophorus investigator

Caelius browni

Piratula insularis

Perizoma grandis

Plateumaris sp.

Javesella pellucida

Callicorixa alaskensis

Scierus annectans

Araneus marmoreus

Nicrophorus defodiens

Perizoma grandis

Lypoglossa angularis angularis

Lederia arctica

Triarthron lecontei

Carabus truncaticollis

Hybomitra arpadi

Stenodema trispinosa

Stenodema trispinosa

Clubiona moesta

Coccinella septempunctata

Coccinella septempunctata

Aeshna sitchensis

Agnocoris rubicundus

Agoliinus piceatus

Agyneta olivacea

Arctosa alpigena

Bembidion quadrifoveolatum

Boloria grandis

Caelius montana

Carabus chamissonis

Cheilosia laevis

Cheilosia latrans

Coccinella septempunctata

Culiseta alaskaensis

Cyclosa conica

Cyclosa conica

Elasmostethus interstinctus

Formica subaenescens

Galerucella nymphaeae

Hadrotes crassus

Javesella pellucida

Liogluta trapezicollis

\begin{tabular}{|c|c|c|c|}
\hline UAMIC1114-13 & Tipula limbata & UAMIC1115-13 & 0.3642987 \\
\hline UAMIC743-13 & Bombus melanopygus & UAMIC744-13 & 0.3442341 \\
\hline UAMIC1504-13 & Araniella displicata & UAMIC1442-13 & 0.3436426 \\
\hline UAMIC1962-14 & Philaenarcys bilineata & UAMIC1932-14 & 0.3378379 \\
\hline UAMIC1939-14 & Philaenarcys bilineata & UAMIC1962-14 & 0.3378379 \\
\hline UAMIC2072-14 & Plagiognathus brunneus & UAMIC2046-14 & 0.3333333 \\
\hline UAMIC1249-13 & Bathyphantes reprobus & UAMIC1246-13 & 0.331675 \\
\hline UAMIC497-13 & Boloria freija & UAMIC3231-15 & 0.331675 \\
\hline UAMIC3268-15 & Pteromicra angustipennis & UAMIC3270-15 & 0.3284072 \\
\hline UAMIC836-13 & Pristoceuthophilus cercalis & UAMIC710-13 & 0.3273323 \\
\hline UAMIC1474-13 & Araneus trifolium & UAMIC1465-13 & 0.3267974 \\
\hline UAMIC2020-14 & Nabis inscriptus & UAMIC2064-14 & 0.3267974 \\
\hline UAMIC099-13 & Nicrophorus investigator & UAMIC330-13 & 0.3267974 \\
\hline UAMIC174-13 & Caelius browni & UAMIC318-13 & 0.3236246 \\
\hline UAMIC1566-13 & Piratula insularis & UAMIC1432-13 & 0.3236246 \\
\hline UAMIC506-13 & Perizoma grandis & UAMIC1175-13 & 0.3231018 \\
\hline UAMIC2268-14 & Plateumaris sp. & UAMIC2276-14 & 0.3231018 \\
\hline UAMIC580-13 & Javesella pellucida & UAMIC584-13 & 0.3205128 \\
\hline UAMIC2118-14 & Callicorixa alaskensis & UAMIC2180-14 & 0.3189793 \\
\hline UAMIC2212-14 & Scierus annectans & UAMIC2199-14 & 0.317965 \\
\hline UAMIC1505-13 & Araneus marmoreus & UAMIC1479-13 & 0.3174603 \\
\hline UAMIC1880-14 & Nicrophorus defodiens & UAMIC1825-14 & 0.3174603 \\
\hline UAMIC505-13 & Perizoma grandis & UAMIC1175-13 & 0.3174603 \\
\hline UAMIC2742-15 & Lypoglossa angularis angularis & UAMIC2700-15 & 0.3100775 \\
\hline UAMIC251-13 & Lederia arctica & UAMIC149-13 & 0.308642 \\
\hline UAMIC337-13 & Tria & UAMIC1 & 8642 \\
\hline UAMIC027-12 & Carabus truncaticollis & UAMIC331-13 & 0.3081664 \\
\hline UAMIC976-13 & a arpadi & UAMIC979-13 & 0.3072197 \\
\hline UAMIC2063-14 & & & 197 \\
\hline UAMIC2051-14 & Stenodema trispinosa & UAMIC2063-14 & 0.3072197 \\
\hline UAMIC1540-13 & moesta & UAMIC1531-13 & 0.3062787 \\
\hline UAMIC2411-14 & Coccinella septempunctata & UAMIC2441-14 & 0.3062787 \\
\hline UAMIC2453-14 & Coccinella septempunctata & UAMIC2441-14 & 0.3062787 \\
\hline UAMIC849-13 & Aeshna sitchensis & UAMIC844-13 & 0.3058104 \\
\hline UAMIC2162-14 & Agnocoris rubicundus & UAMIC2129-14 & 0.3058104 \\
\hline UAMIC2498-15 & Agoliinus piceatus & UAMIC2484-15 & 0.3058104 \\
\hline UAMIC1238-13 & Agyneta olivacea & UAMIC1244-13 & 0.3058104 \\
\hline UAMIC1471-13 & Arctosa alpigena & UAMIC1433-13 & 0.3058104 \\
\hline UAMIC3410-15 & Bembidion quadrifoveolatum & UAMIC035-12 & 0.3058104 \\
\hline UAMIC3253-15 & Boloria grandis & UAMIC3237-15 & 0.3058104 \\
\hline UAMIC2501-15 & Caelius montana & UAMIC2495-15 & 0.3058104 \\
\hline UAMIC359-13 & Carabus chamisso & UAMIC029-12 & 0.3058104 \\
\hline UAMIC2971-15 & Cheilosia laevis & UAMIC2970-15 & 0.3058104 \\
\hline UAMIC3003-15 & Cheilosia latrans & UAMIC3037-15 & 0.3058104 \\
\hline UAMIC2453-14 & Coccinella septempunctata & UAMIC2411-14 & 0.3058104 \\
\hline UAMIC906-13 & Culiseta alaskaensis & UAMIC905-13 & 0.3058104 \\
\hline UAMIC1488-13 & Cyclosa conica & UAMIC1522-13 & 0.3058104 \\
\hline UAMIC1488-13 & Cyclosa conica & UAMIC1489-13 & 0.3058104 \\
\hline UAMIC577-13 & Elasmostethus interstinctus & UAMIC571-13 & 0.3058104 \\
\hline UAMIC703-13 & Formica subaenescens & UAMIC704-13 & 0.3058104 \\
\hline UAMIC2190-14 & Galerucella nymphaeae & UAMIC2194-14 & 0.3058104 \\
\hline UAMIC2878-15 & Hadrotes crassus & UAMIC1074-13 & 0.3058104 \\
\hline UAMIC584-13 & Javesella pellucida & UAMIC1975-14 & 0.3058104 \\
\hline UAMIC2750-15 & Liogluta trapezicollis & UAMIC2753-15 & 0.305810 \\
\hline
\end{tabular}




\begin{tabular}{|c|c|c|c|c|}
\hline Micrurapteryx salicifoliella & UAMIC431-13 & Micrurapteryx salicifoliella & UAMIC430-13 & 0.3058104 \\
\hline Nebria sahlbergii & UAMIC349-13 & Nebria sahlbergii & UAMIC084-12 & 0.3058104 \\
\hline Nysius angustatus & UAMIC1996-14 & Nysius angustatus & UAMIC1933-14 & 0.3058104 \\
\hline Olophrum consimile & UAMIC1870-14 & Olophrum consimile & UAMIC1822-14 & 0.3058104 \\
\hline Ozyptila sincera & UAMIC1718-14 & Ozyptila sincera & UAMIC1740-14 & 0.3058104 \\
\hline Pardosa xerampelina & UAMIC1555-13 & Pardosa xerampelina & UAMIC1491-13 & 0.3058104 \\
\hline Philodromus placidus & UAMIC1666-13 & Philodromus placidus & UAMIC1558-13 & 0.3058104 \\
\hline Phlaeopterus cavicollis & UAMIC2305-14 & Phlaeopterus cavicollis & UAMIC2374-14 & 0.3058104 \\
\hline Phlaeopterus cavicollis & UAMIC2290-14 & Phlaeopterus cavicollis & UAMIC2374-14 & 0.3058104 \\
\hline Platynus decentis & UAMIC440-13 & Platynus decentis & UAMIC076-12 & 0.3058104 \\
\hline Pteromicra angustipennis & UAMIC3270-15 & Pteromicra angustipennis & UAMIC3285-15 & 0.3058104 \\
\hline Punicealis hamata & UAMIC166-13 & Punicealis hamata & UAMIC247-13 & 0.3058104 \\
\hline Serropalpus substriatus & UAMIC474-13 & Serropalpus substriatus & UAMIC232-13 & 0.3058104 \\
\hline Steatoda borealis & UAMIC1223-13 & Steatoda borealis & UAMIC1214-13 & 0.3058104 \\
\hline Sthereus ptinoides & UAMIC427-13 & Sthereus ptinoides & UAMIC1896-14 & 0.3058104 \\
\hline Tetanocera silvatica & UAMIC3281-15 & Tetanocera silvatica & UAMIC3280-15 & 0.3058104 \\
\hline Zelotes sula & UAMIC1598-13 & Zelotes sula & UAMIC1539-13 & 0.3058104 \\
\hline Zicrona caerulea & UAMIC2007-14 & Zicrona caerulea & UAMIC662-13 & 0.3058104 \\
\hline Bolitobius cingulatus & UAMIC1826-14 & Bolitobius cingulatus & UAMIC1831-14 & 0.2020202 \\
\hline Neochthebius vandykei & UAMIC363-13 & Neochthebius vandykei & UAMIC362-13 & 0.1984127 \\
\hline Bombus mixtus & UAMIC748-13 & Bombus mixtus & UAMIC747-13 & 0.1980198 \\
\hline Chlorochroa rossiana & UAMIC2060-14 & Chlorochroa rossiana & UAMIC597-13 & 0.1926782 \\
\hline Plebejus optilete & UAMIC3265-15 & Plebejus optilete & UAMIC3226-15 & 0.1915709 \\
\hline Compsobata pallipes & UAMIC3033-15 & Compsobata pallipes & UAMIC2988-15 & 0.1893939 \\
\hline Bembidion obscurellum & UAMIC2946-15 & Bembidion obscurellum & UAMIC2448-14 & 0.1766785 \\
\hline Colias palaeno & UAMIC384-13 & Colias palaeno & UAMIC437-13 & 0.1745201 \\
\hline Microneta viaria & UAMIC1461-13 & Microneta viaria & UAMIC1425-13 & 0.174216 \\
\hline Bembidion nigripes & UAMIC3392-15 & Bembidion nigripes & UAMIC3391-15 & 0.1730104 \\
\hline Dienerella filum & UAMIC3274-15 & Dienerella filum & UAMIC3273-15 & 0.1730104 \\
\hline Javesella pellucida & UAMIC1967-14 & Javesella pellucida & UAMIC580-13 & 0.1727116 \\
\hline Rhogogaster viridis & UAMIC830-13 & Rhogogaster viridis & UAMIC766-13 & 0.1727116 \\
\hline Chlorochroa rossiana & UAMIC2060-14 & Chlorochroa rossiana & UAMIC598-13 & 0.1724138 \\
\hline Chlorochroa rossiana & UAMIC2060-14 & Chlorochroa rossiana & UAMIC2019-14 & 0.1724138 \\
\hline Chlorochroa rossiana & UAMIC2058-14 & Chlorochroa rossiana & UAMIC2060-14 & 0.1724138 \\
\hline Bembidion obscurellum & UAMIC2946-15 & Bembidion obscurellum & UAMIC2898-15 & 0.1703578 \\
\hline Diarsia esurialis & UAMIC559-13 & Diarsia esurialis & UAMIC554-13 & 0.170068 \\
\hline Sciastes mentasta & UAMIC1346-13 & Sciastes mentasta & UAMIC1625-13 & 0.1686341 \\
\hline Nabis inscriptus & UAMIC2064-14 & Nabis inscriptus & UAMIC2013-14 & 0.1683502 \\
\hline Xysticus ferox & UAMIC1728-14 & Xysticus ferox & UAMIC1801-14 & 0.1683502 \\
\hline Loricera decempunctata & UAMIC2859-15 & Loricera decempunctata & UAMIC2936-15 & 0.1677852 \\
\hline Alydus eurinus & UAMIC1903-14 & Alydus eurinus & UAMIC1963-14 & 0.1675042 \\
\hline Alydus eurinus & UAMIC1903-14 & Alydus eurinus & UAMIC1949-14 & 0.1675042 \\
\hline Olethreutes glaciana & UAMIC462-13 & Olethreutes glaciana & UAMIC465-13 & 0.1675042 \\
\hline Plagiognathus brunneus & UAMIC2037-14 & Plagiognathus brunneus & UAMIC2046-14 & 0.1666667 \\
\hline Boreus borealis & UAMIC852-13 & Boreus borealis & UAMIC853-13 & 0.1658375 \\
\hline Chiloxanthus stellatus & UAMIC2139-14 & Chiloxanthus stellatus & UAMIC2154-14 & 0.1658375 \\
\hline Cicurina simplex & UAMIC1681-13 & Cicurina simplex & UAMIC1657-13 & 0.1658375 \\
\hline Javesella pellucida & UAMIC1967-14 & Javesella pellucida & UAMIC1975-14 & 0.1658375 \\
\hline Trapezonotus arenarius & UAMIC1946-14 & Trapezonotus arenarius & UAMIC1954-14 & 0.1658375 \\
\hline Vespula acadica & UAMIC700-13 & Vespula acadica & UAMIC668-13 & 0.1658375 \\
\hline Agnocoris rubicundus & UAMIC2129-14 & Agnocoris rubicundus & UAMIC2161-14 & 0.1633987 \\
\hline Agnocoris rubicundus & UAMIC2162-14 & Agnocoris rubicundus & UAMIC2161-14 & 0.1633987 \\
\hline Boreophilia nearctica & UAMIC2724-15 & Boreophilia nearctica & UAMIC2729-15 & 0.1633987 \\
\hline Mniusa yukonensis & UAMIC2689-15 & Mniusa yukonensis & UAMIC2715-15 & 0.1628664 \\
\hline
\end{tabular}


Rheumaptera subhastata

Diarsia esurialis

Bembidion obscurellum

Acidota quadrata

Atrecus quadripennis

Pelecomalium sp.

Teloleuca bifasciata

Amara patruelis

Pardosa uintana

Syngrapha viridisigma

Araneus marmoreus

Callicorixa vulnerata

Plemyria georgii

Dendroctonus rufipennis

Pinalitus approximatus

Apotomis removana

Pherbellia nana

Pherbellia nana

Selatosomus morulus

Lycaena dorcas

Carabus vietinghoffii

Notaris aethiops

Notaris aethiops

Phlaeopterus houkae

Bradycellus nigrinus

Epuraea terminalis

Rhyncolus brunneus

Wyochernes asiaticus

Callicorixa vulnerata

Chlamydatus keltoni

Epiphanis cornutus

Phalangium opilio

Phalangium opilio

Amara patruelis

Atheta circulicollis

Byturus unicolor

Dictyoptera simplicipes

Eana osseana

Planolinus tenellus

Plectrura spinicauda

Saldula laticollis

Agoliinus congregatus

Agoliinus congregatus

Agoliinus congregatus

Agoliinus congregatus

Agoliinus congregatus

Agonum affine

Agonum gratiosum

Aleochara castaneipennis

Amara obesa

Amara patruelis

Amara patruelis

Apamea sora

Apotomis removana

$\begin{array}{ll}\text { UAMIC512-13 } & \text { Rheumaptera subhastata } \\ \text { UAMIC553-13 } & \text { Diarsia esurialis } \\ \text { UAMIC2946-15 } & \text { Bembidion obscurellum } \\ \text { UAMIC1818-14 } & \text { Acidota quadrata } \\ \text { UAMIC1137-13 } & \text { Atrecus quadripennis } \\ \text { UAMIC2315-14 } & \text { Pelecomalium sp. } \\ \text { UAMIC2128-14 } & \text { Teloleuca bifasciata } \\ \text { UAMIC2418-14 } & \text { Amara patruelis } \\ \text { UAMIC1536-13 } & \text { Pardosa uintana } \\ \text { UAMIC530-13 } & \text { Syngrapha viridisigma } \\ \text { UAMIC1518-13 } & \text { Araneus marmoreus } \\ \text { UAMIC2187-14 } & \text { Callicorixa vulnerata } \\ \text { UAMIC503-13 } & \text { Plemyria georgii } \\ \text { UAMIC2206-14 } & \text { Dendroctonus rufipennis } \\ \text { UAMIC2049-14 } & \text { Pinalitus approximatus } \\ \text { UAMIC3148-15 } & \text { Apotomis removana } \\ \text { UAMIC3308-15 } & \text { Pherbellia nana } \\ \text { UAMIC3308-15 } & \text { Pherbellia nana } \\ \text { UAMIC406-13 } & \text { Selatosomus morulus } \\ \text { UAMIC3205-15 } & \text { Lycaena dorcas } \\ \text { UAMIC307-13 } & \text { Carabus vietinghoffii } \\ \text { UAMIC453-13 } & \text { Notaris aethiops } \\ \text { UAMIC2493-15 } & \text { Agoliinus congregatus } \\ \text { UAMIC095-12 } & \text { Agonum affine } \\ \text { UAMIC2545-15 } & \text { Aleochara castaneipennis } \\ \text { UAMIC455-13 } & \text { Amara obesa } \\ \text { UAMIC2373-14 } & \text { Notaris aethiops } \\ \text { UAMIC1809-14 } & \text { Amara patruelis } \\ \text { UAMIC032-12 } & \text { Bradycellus nigrinus } \\ \text { UAMIC293-13 } & \text { Epuraea terminalis } \\ \text { UAMIC3176-15 } & \text { Apamea sora } \\ \text { UAMIC179-13 } & \text { Rhyncolus brunneus } \\ \text { UAMIC3146-15 } & \text { Apotomis removana } \\ \text { UAMIC1720-14 } & \text { Wyochernes asiaticus } \\ \text { UAMIC2121-14 } & \text { Callicorixa vulnerata } \\ \text { UAMIC2116-14 } & \text { Chlamydatus keltoni } \\ \text { UAMIC457-13 } & \text { Epiphanis cornutus } \\ \text { UAMIC1738-14 } & \text { Phalangium opilio } \\ \text { UAMIC1803-14 } & \text { Phalangium opilio } \\ \text { UAMIC2449-14 } & \text { Amara patruelis } \\ \text { UAMIC2660-15 } & \text { Atheta circulicollis } \\ \text { UAMIC2526-15 } & \text { Byturus unicolor } \\ \text { UAMIC154-13 } & \text { Dictyoptera simplicipes } \\ \text { UAMIC3178-15 } & \text { Eana osseana } \\ \text { UA-15 } & \text { Plectrura spinicauda } \\ \text { UAmoliinus congregatus } \\ \text { UAm }\end{array}$

\begin{tabular}{|c|c|}
\hline UAMIC513-13 & 5016 \\
\hline UAMIC554-13 & 0.1618123 \\
\hline UAMIC2391-14 & 0.1612903 \\
\hline UAMIC2496-15 & 0.1610306 \\
\hline UAMIC1881-14 & 0.1610306 \\
\hline UAMIC2365-14 & 0.1610306 \\
\hline UAMIC2111-14 & 0.1602564 \\
\hline UAMIC1838-14 & 0.1597444 \\
\hline UAMIC1535-13 & 0.1594896 \\
\hline UAMIC531-13 & 0.1594896 \\
\hline UAMIC1505-13 & 0.1587302 \\
\hline UAMIC2097-14 & 0.1587302 \\
\hline UAMIC504-13 & 0.1587302 \\
\hline UAMIC2278-14 & 0.1579779 \\
\hline UAMIC2048-14 & 0.1579779 \\
\hline UAMIC3144-15 & 0.1572327 \\
\hline UAMIC3305-15 & 0.1572327 \\
\hline UAMIC3307-15 & 0.1572327 \\
\hline UAMIC111-13 & 0.1572327 \\
\hline UAMIC3221-15 & 0.1564945 \\
\hline UAMIC2467-14 & 0.1550388 \\
\hline UAMIC242-13 & 0.1550388 \\
\hline UAMIC242-13 & 0.1550388 \\
\hline UAMIC2310-14 & 0.154321 \\
\hline UAMIC2871-15 & 0.1536098 \\
\hline UAMIC214-13 & 0.1536098 \\
\hline UAMIC275-13 & 0.1536098 \\
\hline UAMIC1734-14 & 0.1536098 \\
\hline UAMIC2187-14 & 0.1533742 \\
\hline UAMIC2131-14 & 0.1533742 \\
\hline UAMIC142-13 & 0.1533742 \\
\hline UAMIC1797-14 & 0.1533742 \\
\hline UAMIC1738-14 & 0.1533742 \\
\hline UAMIC2420-14 & 0.1531394 \\
\hline UAMIC2661-15 & 0.1531394 \\
\hline UAMIC2527-15 & 0.1531394 \\
\hline UAMIC246-13 & 0.1531394 \\
\hline UAMIC3090-15 & 0.1531394 \\
\hline UAMIC2564-15 & 0.1531394 \\
\hline UAMIC254-13 & 0.1531394 \\
\hline UAMIC2132-14 & 0.1531394 \\
\hline UAMIC2494-15 & 0.1529052 \\
\hline UAMIC2494-15 & 0.1529052 \\
\hline UAMIC2494-15 & 0.1529052 \\
\hline UAMIC2494-15 & 0.1529052 \\
\hline UAMIC2494-15 & 0.1529052 \\
\hline UAMIC450-13 & 0.1529052 \\
\hline UAMIC454-13 & 0.1529052 \\
\hline UAMIC2542-15 & 0.1529052 \\
\hline UAMIC062-12 & 0.1529052 \\
\hline UAMIC2420-14 & 0.1529052 \\
\hline UAMIC2420-14 & 0.1529052 \\
\hline UAMIC3083-15 & 0.1529052 \\
\hline UAMIC3148-15 & 0.1529052 \\
\hline
\end{tabular}


Araneus marmoreus

Araneus nordmanni

Bembidion curtulatum

Bembidion yukonum

Boloria grandis

Boloria grandis

Boloria grandis

Boloria grandis

Bombus frigidus

Bombus occidentalis

Bombus perplexus

Botanophila spinidens

Callicorixa audeni

Callicorixa audeni

Campsicnemus degener

Carabus vietinghoffii

Cheilosia borealis

Cheilosia yukonensis

Cixius meridionalis

Clinocera nivalis

Coenosia pilosissima

Dolichopus remipes

Drassodes mirus

Dryocoetes autographus

Dryocoetes autographus

Eana osseana

Elaphrus americanus

Eupeodes curtus

Formica neorufibarbis

Formica podzolica

Galerucella nymphaeae

Galerucella nymphaeae

Geocoris howardi

Gerris incognitus

Gerris incognitus

Hesperia comma

Hydrellia griseola

Hyppa contrasta

Hypsosinga rubens

Icaricia saepiolus

Liogluta trapezicollis

Liogluta trapezicollis

Liogluta trapezicollis

Liogluta trapezicollis

Melanophthalma helvola

Melanoplus borealis

Microprosopa pallidicauda

Mitopus morio

Mniotype tenera

Nebria frigida

Neon reticulatus

Ochlerotatus sticticus

Oxyporus occipitalis

Papilio canadensis

\begin{tabular}{|c|c|}
\hline UAMIC1518-13 & Araneus marmoreus \\
\hline UAMIC1468-13 & Araneus nordmanni \\
\hline UAMIC038-12 & Bembidion curtulatum \\
\hline UAMIC034-12 & Bembidion yukonum \\
\hline UAMIC3237-15 & Boloria grandis \\
\hline UAMIC3253-15 & Boloria grandis \\
\hline UAMIC3364-15 & Boloria grandis \\
\hline UAMIC3364-15 & Boloria grandis \\
\hline UAMIC735-13 & Bombus frigidus \\
\hline UAMIC751-13 & Bombus occidentalis \\
\hline UAMIC741-13 & Bombus perplexus \\
\hline UAMIC1028-13 & Botanophila spinidens \\
\hline UAMIC2143-14 & Callicorixa audeni \\
\hline UAMIC2126-14 & Callicorixa audeni \\
\hline UAMIC883-13 & Campsicnemus degener \\
\hline UAMIC022-12 & Carabus vietinghoffii \\
\hline UAMIC993-13 & Cheilosia borealis \\
\hline UAMIC2959-15 & Cheilosia yukonensis \\
\hline UAMIC574-13 & Cixius meridionalis \\
\hline UAMIC1045-13 & Clinocera nivalis \\
\hline UAMIC3030-15 & Coenosia pilosissima \\
\hline UAMIC899-13 & Dolichopus remipes \\
\hline UAMIC1561-13 & Drassodes mirus \\
\hline UAMIC182-13 & Dryocoetes autographus \\
\hline UAMIC2266-14 & Dryocoetes autographus \\
\hline UAMIC3185-15 & Eana osseana \\
\hline UAMIC1830-14 & Elaphrus americanus \\
\hline UAMIC2965-15 & Eupeodes curtus \\
\hline UAMIC683-13 & Formica neorufibarbis \\
\hline UAMIC686-13 & Formica podzolica \\
\hline UAMIC2243-14 & Galerucella nymphaeae \\
\hline UAMIC2190-14 & Galerucella nymphaeae \\
\hline UAMIC1913-14 & Geocoris howardi \\
\hline UAMIC2106-14 & Gerris incognitus \\
\hline UAMIC2106-14 & Gerris incognitus \\
\hline UAMIC3220-15 & Hesperia comma \\
\hline UAMIC1010-13 & Hydrellia griseola \\
\hline UAMIC3183-15 & Hyppa contrasta \\
\hline UAMIC1486-13 & Hypsosinga rubens \\
\hline UAMIC3208-15 & Icaricia saepiolus \\
\hline UAMIC2753-15 & Liogluta trapezicollis \\
\hline UAMIC2696-15 & Liogluta trapezicollis \\
\hline UAMIC2750-15 & Liogluta trapezicollis \\
\hline UAMIC2750-15 & Liogluta trapezicollis \\
\hline UAMIC3330-15 & Melanophthalma helvola \\
\hline UAMIC712-13 & Melanoplus borealis \\
\hline UAMIC3024-15 & Microprosopa pallidicauda \\
\hline UAMIC1756-14 & Mitopus morio \\
\hline UAMIC1173-13 & Mniotype tenera \\
\hline UAMIC294-13 & Nebria frigida \\
\hline UAMIC1739-14 & Neon reticulatus \\
\hline UAMIC875-13 & Ochlerotatus sticticus \\
\hline UAMIC195-13 & Oxyporus occipitalis \\
\hline UAMIC388-13 & Papilio canadensis \\
\hline
\end{tabular}

\begin{tabular}{|c|c|}
\hline UAMIC1479-13 & 0.1529052 \\
\hline UAMIC1513-13 & 0.1529052 \\
\hline UAMIC367-13 & 0.1529052 \\
\hline UAMIC366-13 & 0.1529052 \\
\hline UAMIC3248-15 & 0.1529052 \\
\hline UAMIC3248-15 & 0.1529052 \\
\hline UAMIC3237-15 & 0.1529052 \\
\hline UAMIC3253-15 & 0.1529052 \\
\hline UAMIC734-13 & 0.1529052 \\
\hline UAMIC752-13 & 0.1529052 \\
\hline UAMIC742-13 & 0.1529052 \\
\hline UAMIC1032-13 & 0.1529052 \\
\hline UAMIC2109-14 & 0.1529052 \\
\hline UAMIC2143-14 & 0.1529052 \\
\hline UAMIC878-13 & 0.1529052 \\
\hline UAMIC2467-14 & 0.1529052 \\
\hline UAMIC992-13 & 0.1529052 \\
\hline UAMIC3039-15 & 0.1529052 \\
\hline UAMIC624-13 & 0.1529052 \\
\hline UAMIC1046-13 & 0.1529052 \\
\hline UAMIC2952-15 & 0.1529052 \\
\hline UAMIC896-13 & 0.1529052 \\
\hline UAMIC1548-13 & 0.1529052 \\
\hline UAMIC2281-14 & 0.1529052 \\
\hline UAMIC2281-14 & 0.1529052 \\
\hline UAMIC3090-15 & 0.1529052 \\
\hline UAMIC058-12 & 0.1529052 \\
\hline UAMIC2957-15 & 0.1529052 \\
\hline UAMIC693-13 & 0.1529052 \\
\hline UAMIC687-13 & 0.1529052 \\
\hline UAMIC2194-14 & 0.1529052 \\
\hline UAMIC2243-14 & 0.1529052 \\
\hline UAMIC1991-14 & 0.1529052 \\
\hline UAMIC2119-14 & 0.1529052 \\
\hline UAMIC2120-14 & 0.1529052 \\
\hline UAMIC3422-15 & 0.1529052 \\
\hline UAMIC1009-13 & 0.1529052 \\
\hline UAMIC3190-15 & 0.1529052 \\
\hline UAMIC1469-13 & 0.1529052 \\
\hline UAMIC3263-15 & 0.1529052 \\
\hline UAMIC2740-15 & 0.1529052 \\
\hline UAMIC2753-15 & 0.1529052 \\
\hline UAMIC2740-15 & 0.1529052 \\
\hline UAMIC2696-15 & 0.1529052 \\
\hline UAMIC3331-15 & 0.1529052 \\
\hline UAMIC711-13 & 0.1529052 \\
\hline UAMIC2999-15 & 0.1529052 \\
\hline UAMIC1743-14 & 0.1529052 \\
\hline UAMIC3062-15 & 0.1529052 \\
\hline UAMIC081-12 & 0.1529052 \\
\hline UAMIC1806-14 & 0.1529052 \\
\hline UAMIC901-13 & 0.1529052 \\
\hline UAMIC196-13 & 0.1529052 \\
\hline UAMIC460-13 & 0.1529052 \\
\hline
\end{tabular}


Parastichtis suspecta

Parastichtis suspecta

Patrobus foveocollis

Phalangium opilio

Phalangium opilio

Philhygra jarmilae

Philhygra jarmilae

Philonthus politus

Philonthus politus

Phlaeopterus houkae

Pinalitus approximatus

Placusa vaga

Polia nimbosa

Prepops nigripilus

Prepops nigripilus

Protophormia terraenovae

Pterostichus adstrictus

Rhagium inquisitor

Scaphinotus angusticollis

Scoliocentra fraterna

Scolopostethus thomsoni

Sicya macularia

Sigara decoratella

Sigara fallenoidea

Sisicottus panopeus

Sitona lineellus

Stenodema pilosipes

Suillia convergens

Syntomus americanus

Teloleuca bifasciata

Tetanocera fuscinervis

Tipula aleutica

Xestia finatimis

Xylena thoracica

Xylota subfasciata

Xysticus canadensis

Abagrotis placida

Acmaeops proteus

Acmaeops proteus

Acmaeops proteus

Acruliopsis tumidula

Actebia fennica

Adalia bipunctata

Adelphocoris rapidus

Adelphocoris rapidus

Adelphocoris rapidus

Aegialia criddlei

Aelia americana

Aeshna eremita

Aeshna juncea

Aeshna septentrionalis

Aeshna subarctica

Agoliinus congregatus

Agoliinus congregatus
UAMIC3063-15

UAMIC051-12 Patrobus foveocollis

UAMIC1804-14 Phalangium opilio

UAMIC1803-14 Phalangium opilio

UAMIC2805-15 Philhygra jarmilae

UAMIC2805-15 Philhygra jarmilae

UAMIC417-13 Philonthus politus

UAMIC2910-15 Philonthus politus

UAMIC2369-14

UAMIC2050-14

UAMIC2794-15

UAMIC3049-15

UAMIC2000-14

UAMIC2000-14

UAMIC865-13

UAMIC013-12

UAMIC177-13

UAMIC026-12

UAMIC1001-13

UAMIC1990-14

UAMIC3065-15

UAMIC2112-14

UAMIC2170-14

UAMIC1368-13

UAMIC422-13

UAMIC2031-14

UAMIC3282-15

UAMIC394-13

UAMIC2128-14

UAMIC3262-15

UAMIC1122-13

UAMIC3112-15

UAMIC3153-15

UAMIC3020-15

UAMIC1721-14

UAMIC3084-15

UAMIC2458-14

UAMIC2408-14

UAMIC2408-14

UAMIC2296-14

UAMIC3071-15

UAMIC2384-14

UAMIC2173-14

UAMIC2108-14

UAMIC2108-14

UAMIC2492-15

UAMIC596-13

UAMIC839-13

UAMIC837-13

UAMIC787-13

UAMIC789-13

UAMIC2514-15

UAMIC2512-15
Phlaeopterus houkae

Pinalitus approximatus

Placusa vaga

Polia nimbosa

Prepops nigripilus

Prepops nigripilus

Protophormia terraenovae

Pterostichus adstrictus

Rhagium inquisitor

Scaphinotus angusticollis

Scoliocentra fraterna

Scolopostethus thomsoni

Sicya macularia

Sigara decoratella

Sigara fallenoidea

Sisicottus panopeus

Sitona lineellus

Stenodema pilosipes

Suillia convergens

Syntomus americanus

Teloleuca bifasciata

Tetanocera fuscinervis

Tipula aleutica

Xestia finatimis

Xylena thoracica

Xylota subfasciata

Xysticus canadensis

Abagrotis placida

Acmaeops proteus

Acmaeops proteus

Acmaeops proteus

Acruliopsis tumidula

Actebia fennica

Adalia bipunctata

Adelphocoris rapidus

Adelphocoris rapidus

Adelphocoris rapidus

Aegialia criddlei

Aelia americana

Aeshna eremita

Aeshna juncea

Aeshna septentrionalis

Aeshna subarctica

Agoliinus congregatus

Agoliinus congregatus

\begin{tabular}{|c|c|}
\hline UAMIC3162-15 & 0.1529052 \\
\hline UAMIC3162-15 & 0.1529052 \\
\hline UAMIC434-13 & 0.1529052 \\
\hline UAMIC1797-14 & 0.1529052 \\
\hline UAMIC1804-14 & 0.1529052 \\
\hline UAMIC2772-15 & 0.1529052 \\
\hline UAMIC2806-15 & 0.1529052 \\
\hline UAMIC125-13 & 0.1529052 \\
\hline UAMIC417-13 & 0.1529052 \\
\hline UAMIC2373-14 & 0.1529052 \\
\hline UAMIC2048-14 & 0.1529052 \\
\hline UAMIC2764-15 & 0.1529052 \\
\hline UAMIC3080-15 & 0.1529052 \\
\hline UAMIC2076-14 & 0.1529052 \\
\hline UAMIC2001-14 & 0.1529052 \\
\hline UAMIC902-13 & 0.1529052 \\
\hline UAMIC313-13 & 0.1529052 \\
\hline UAMIC273-13 & 0.1529052 \\
\hline UAMIC312-13 & 0.1529052 \\
\hline UAMIC999-13 & 0.1529052 \\
\hline UAMIC1964-14 & 0.1529052 \\
\hline UAMIC3068-15 & 0.1529052 \\
\hline UAMIC2104-14 & 0.1529052 \\
\hline UAMIC2157-14 & 0.1529052 \\
\hline UAMIC1407-13 & 0.1529052 \\
\hline UAMIC218-13 & 0.1529052 \\
\hline UAMIC2061-14 & 0.1529052 \\
\hline UAMIC3284-15 & 0.1529052 \\
\hline UAMIC064-12 & 0.1529052 \\
\hline UAMIC2148-14 & 0.1529052 \\
\hline UAMIC3407-15 & 0.1529052 \\
\hline UAMIC1123-13 & 0.1529052 \\
\hline UAMIC3101-15 & 0.1529052 \\
\hline UAMIC3166-15 & 0.1529052 \\
\hline UAMIC3019-15 & 0.1529052 \\
\hline UAMIC1791-14 & 0.1529052 \\
\hline UAMIC3114-15 & 0 \\
\hline UAMIC2404-14 & 0 \\
\hline UAMIC2404-14 & 0 \\
\hline UAMIC2458-14 & 0 \\
\hline UAMIC2335-14 & 0 \\
\hline UAMIC3072-15 & 0 \\
\hline UAMIC2430-14 & 0 \\
\hline UAMIC2185-14 & 0 \\
\hline UAMIC2185-14 & 0 \\
\hline UAMIC2173-14 & 0 \\
\hline UAMIC2502-15 & 0 \\
\hline UAMIC602-13 & 0 \\
\hline UAMIC842-13 & 0 \\
\hline UAMIC785-13 & 0 \\
\hline UAMIC786-13 & 0 \\
\hline UAMIC788-13 & 0 \\
\hline UAMIC2515-15 & 0 \\
\hline UAMIC2515-15 & 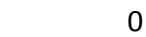 \\
\hline
\end{tabular}


Agoliinus congregatus Agoliinus congregatus Agoliinus congregatus Agoliinus congregatus Agoliinus congregatus Agoliinus congregatus Agoliinus congregatus Agoliinus congregatus Agoliinus leopardus Agonum cupreum Agrotis vancouverensis Aleochara sp. Alopecosa aculeata Alydus calcaratus Alydus eurinus Amara alpina Amara glacialis Amara interstitialis Amara lunicollis Amara lunicollis Amara lunicollis Amara patruelis Amara patruelis Amara patruelis Amara torrida Amblopusa nr. brevipes Amblopusa nr. brevipes Amblopusa nr. brevipes Ampedus apicatus Anania funebris Anaplectoides prasina Anaplectoides pressus Anaspis rufa Andropolia contacta Anteon osborni Anthocoris musculus Apamea cogitata Apis mellifera Apotomis removana Apotomis tertiana Araeopidius monachus Araneus saevus Araneus trifolium Arctobius agelenoides Arctosa insignita Argenna obesa Arphia conspersa Atractotomus cooperi Atractotomus cooperi Atractotomus cooperi Atrecus macrocephalus Autalia truncatula Autalia truncatula Autalia truncatula

\begin{tabular}{|c|c|}
\hline UAMIC2512-15 & Agoliinus congregatus \\
\hline JAMIC2500-15 & Agoliinus congregatus \\
\hline UAMIC2500-15 & Agoliinus congregatus \\
\hline UAMIC2500-15 & Agoliinus congregatus \\
\hline UAMIC2493-15 & Agoliinus congregatus \\
\hline UAMIC2493-15 & Agoliinus congregatus \\
\hline UAMIC2493-15 & Agoliinus congregatus \\
\hline UAMIC2493-15 & Agoliinus congregatus \\
\hline UAMIC2513-15 & Agoliinus leopardus \\
\hline UAMIC071-12 & Agonum cupreum \\
\hline UAMIC3179-15 & Agrotis vancouverensis \\
\hline UAMIC2567-15 & Aleochara sp. \\
\hline UAMIC1446-13 & Alopecosa aculeata \\
\hline UAMIC1958-14 & Alydus calcaratus \\
\hline UAMIC1949-14 & Alydus eurinus \\
\hline UAMIC1898-14 & Amara alpina \\
\hline UAMIC009-12 & Amara glacialis \\
\hline UAMIC1890-14 & Amara interstitialis \\
\hline UAMIC2885-15 & Amara lunicollis \\
\hline UAMIC2867-15 & Amara luni \\
\hline UAMIC2867-15 & Amara lun \\
\hline UAMIC2390-14 & Amara patruelis \\
\hline UAMIC2449-14 & Amara pat \\
\hline UAMIC2449-14 & Am \\
\hline UAMIC290-13 & Amara torrida \\
\hline UAMIC2522-15 & Amblopusa nr. brevipes \\
\hline UAMIC2519-15 & Amblopusa nr. brevipes \\
\hline UAMIC2519-15 & Amblopusa nr. brevipes \\
\hline UAMIC412-13 & Ampedus apicatus \\
\hline UAMIC3172-15 & \\
\hline UAMIC3116-15 & Anaplectoides prasina \\
\hline UAMIC3189-15 & Anaplectoides pressus \\
\hline UAMIC234-13 & Anaspis rufa \\
\hline UAMIC561-13 & Andropolia contacta \\
\hline UAMIC715-13 & Anteon osborni \\
\hline UAMIC2069-14 & Anthocoris musculus \\
\hline UAMIC558-13 & Apamea cogitata \\
\hline UAMIC723-13 & Apis mellifera \\
\hline UAMIC3146-15 & Apotomis removana \\
\hline UAMIC3143-15 & Apotomis tertiana \\
\hline UAMIC157-13 & Araeopidius monachus \\
\hline UAMIC1493-13 & Araneus saevus \\
\hline UAMIC1460-13 & Araneus trifolium \\
\hline UAMIC1591-13 & Arctobius agelenoides \\
\hline UAMIC1445-13 & Arctosa insignita \\
\hline UAMIC1570-13 & Argenna obesa \\
\hline UAMIC589-13 & Arphia conspersa \\
\hline UAMIC2166-14 & Atractotomus cooperi \\
\hline UAMIC2167-14 & Atractotomus cooperi \\
\hline UAMIC2167-14 & Atractotomus cooperi \\
\hline UAMIC135-13 & Atrecus macrocephalus \\
\hline UAMIC2671-15 & Autalia truncatula \\
\hline UAMIC2666-15 & Autalia truncatula \\
\hline UAMIC2666-15 & Autalia truncatula \\
\hline
\end{tabular}

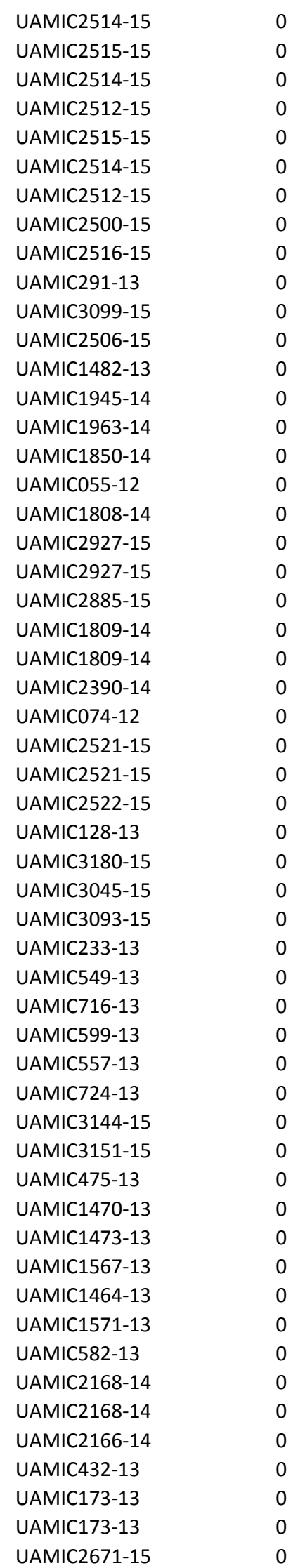




\begin{tabular}{|c|c|c|c|}
\hline Autalia truncatula & UAMIC2726-15 & Autalia truncatula & UAMIC173-13 \\
\hline Autalia truncatula & UAMIC2726-15 & Autalia truncatula & UAMIC2671-15 \\
\hline Autalia truncatula & UAMIC2726-15 & Autalia truncatula & UAMIC2666-15 \\
\hline Autographa buraetica & UAMIC556-13 & Autographa buraetica & UAMIC555-13 \\
\hline Autographa pseudogamma & UAMIC1145-13 & Autographa pseudogamma & UAMIC3075-15 \\
\hline Bathyphantes keeni & UAMIC1662-13 & Bathyphantes keeni & UAMIC1637-13 \\
\hline Bembidion bimaculatum & UAMIC3394-15 & Bembidion bimaculatum & UAMIC3393-15 \\
\hline Bembidion bimaculatum & UAMIC3398-15 & Bembidion bimaculatum & UAMIC3393-15 \\
\hline Bembidion bimaculatum & UAMIC3398-15 & Bembidion bimaculatum & UAMIC3394-15 \\
\hline Bembidion grapii & UAMIC3412-15 & Bembidion grapii & UAMIC3379-15 \\
\hline Bembidion grapii & UAMIC3401-15 & Bembidion grapii & UAMIC3379-15 \\
\hline Bembidion grapii & UAMIC3401-15 & Bembidion grapii & UAMIC3412-15 \\
\hline Bembidion gratiosum & UAMIC042-12 & Bembidion gratiosum & UAMIC370-13 \\
\hline Bembidion haruspex & UAMIC2870-15 & Bembidion haruspex & UAMIC2912-15 \\
\hline Bembidion haruspex & UAMIC2923-15 & Bembidion haruspex & UAMIC2912-15 \\
\hline Bembidion haruspex & UAMIC2923-15 & Bembidion haruspex & UAMIC2870-15 \\
\hline Bembidion hastii & UAMIC3402-15 & Bembidion hastii & UAMIC3404-15 \\
\hline Bembidion inaequale & UAMIC3395-15 & Bembidion inaequale & UAMIC3397-15 \\
\hline Bembidion obscurellum & UAMIC2391-14 & Bembidion obscurellum & UAMIC2448-14 \\
\hline Bembidion obscurellum & UAMIC2898-15 & Bembidion obscurellum & UAMIC2448-14 \\
\hline Bembidion obscurellum & UAMIC2898-15 & Bembidion obscurellum & UAMIC2391-14 \\
\hline Bembidion rusticum lenensoides & UAMIC3416-15 & Bembidion rusticum lenensoides & UAMIC3415-15 \\
\hline Bembidion scopulinum & UAMIC376-13 & Bembidion scopulinum & UAMIC036-12 \\
\hline Bembidion transparens & UAMIC053-12 & Bembidion transparens & UAMIC403-13 \\
\hline Blaesoxipha atlanis & UAMIC2989-15 & Blaesoxipha atlanis & UAMIC2956-15 \\
\hline Blaesoxipha sp. & UAMIC3011-15 & Blaesoxipha sp. & UAMIC2997-15 \\
\hline Boloria chariclea & UAMIC487-13 & Boloria chariclea & UAMIC488-13 \\
\hline Boloria chariclea & UAMIC3246-15 & Boloria chariclea & UAMIC3204-15 \\
\hline Boloria grandis & UAMIC3364-15 & Boloria grandis & UAMIC3248-15 \\
\hline Bombus ashtoni & UAMIC740-13 & Bombus ashtoni & UAMIC738-13 \\
\hline Bombus ashtoni & UAMIC739-13 & Bombus ashtoni & UAMIC738-13 \\
\hline Bombus ashtoni & UAMIC739-13 & Bombus ashtoni & UAMIC740-13 \\
\hline Bombus bifarius & UAMIC731-13 & Bombus bifarius & UAMIC730-13 \\
\hline Bombus centralis & UAMIC746-13 & Bombus centralis & UAMIC745-13 \\
\hline Bombus insularis & UAMIC732-13 & Bombus insularis & UAMIC733-13 \\
\hline Bombus jonellus & UAMIC750-13 & Bombus jonellus & UAMIC749-13 \\
\hline Bombus moderatus & UAMIC753-13 & Bombus moderatus & UAMIC754-13 \\
\hline Botanophila hucketti & UAMIC994-13 & Botanophila hucketti & UAMIC995-13 \\
\hline Byturus unicolor & UAMIC2527-15 & Byturus unicolor & UAMIC2528-15 \\
\hline Byturus unicolor & UAMIC2526-15 & Byturus unicolor & UAMIC2528-15 \\
\hline Cabera exanthemata & UAMIC533-13 & Cabera exanthemata & UAMIC532-13 \\
\hline Calathus ingratus & UAMIC310-13 & Calathus ingratus & UAMIC017-12 \\
\hline Callicorixa audeni & UAMIC2126-14 & Callicorixa audeni & UAMIC2109-14 \\
\hline Callicorixa vulnerata & UAMIC2121-14 & Callicorixa vulnerata & UAMIC2097-14 \\
\hline Calliphora loewi & UAMIC914-13 & Calliphora loewi & UAMIC915-13 \\
\hline Calliphora terraenovae & UAMIC918-13 & Calliphora terraenovae & UAMIC919-13 \\
\hline Calliphora vomitoria & UAMIC917-13 & Calliphora vomitoria & UAMIC916-13 \\
\hline Calvia quatuordecimguttata & UAMIC266-13 & Calvia quatuordecimguttata & UAMIC262-13 \\
\hline Camnula pellucida & UAMIC590-13 & Camnula pellucida & UAMIC591-13 \\
\hline Camponotus herculeanus & UAMIC679-13 & Camponotus herculeanus & UAMIC678-13 \\
\hline Capsus cinctus & UAMIC2134-14 & Capsus cinctus & UAMIC2122-14 \\
\hline Carabus nemoralis & UAMIC639-13 & Carabus nemoralis & UAMIC1885-14 \\
\hline Carabus taedatus & UAMIC025-12 & Carabus taedatus & UAMIC338-13 \\
\hline Carabus vietinghoffii & UAMIC307-13 & Carabus vietinghoffii & UAMIC022-12 \\
\hline
\end{tabular}




\begin{tabular}{|c|}
\hline Cartodere constricta \\
\hline Catoptria oregonica \\
\hline Ceranemota fasciata \\
\hline Cheilosia bigelowi \\
\hline Chersotis juncta \\
\hline Chloealtis abdominalis \\
\hline Chlorochroa rossiana \\
\hline Chlorochroa rossiana \\
\hline Chlorochroa rossiana \\
\hline Chlorochroa rossiana \\
\hline Chlorochroa rossiana \\
\hline Chlorochroa rossiana \\
\hline Chrysops dawsoni \\
\hline Chrysops furcatus \\
\hline Cicindela oregona \\
\hline Clepsis persicana \\
\hline Clubiona canadensis \\
\hline Clubiona kulczynskii \\
\hline Cnodacophora nasoni \\
\hline Cnodacophora nasoni \\
\hline Cnodacophora nasoni \\
\hline Coccinella transversoguttata \\
\hline Coccinella trifasciata \\
\hline Coenagrion angulatum \\
\hline Coenonympha tullia \\
\hline Colias gigantea \\
\hline Colias kluanensis \\
\hline Colias philodice \\
\hline Coreorgonal monoceros \\
\hline Corticaria impressa \\
\hline Crabro latipes \\
\hline Crambus pascuella \\
\hline Craspedolepta alaskensis \\
\hline Ctenicera angusticollis \\
\hline Cucujus clavipes \\
\hline Cuerna striata \\
\hline Cybaeopsis wabritaska \\
\hline Cybaeus reticulatus \\
\hline Cychrus tuberculatus \\
\hline Cyclophora pendulinaria \\
\hline Cyclosa conica \\
\hline Cymatia americana \\
\hline Cymatia americana \\
\hline Cymatia americana \\
\hline Deinopteroloma subcostatum \\
\hline Delia pilifemur \\
\hline Devia prospera \\
\hline Devia prospera \\
\hline Devia prospera \\
\hline Diarsia dislocata \\
\hline Diarsia esurialis \\
\hline Dicerca tenebrica \\
\hline Ditylus gracilis \\
\hline Ditylus quadricollis \\
\hline
\end{tabular}

\begin{tabular}{|c|c|}
\hline UAMIC3329-15 & Cartodere constricta \\
\hline UAMIC3089-15 & Catoptria oregonica \\
\hline UAMIC3095-15 & Ceranemota fasciata \\
\hline UAMIC3038-15 & Cheilosia bigelowi \\
\hline UAMIC3051-15 & Chersotis juncta \\
\hline UAMIC608-13 & Chloealtis abdominalis \\
\hline UAMIC598-13 & Chlorochroa rossiana \\
\hline UAMIC2019-14 & Chlorochroa rossiana \\
\hline UAMIC2019-14 & Chlorochroa rossiana \\
\hline UAMIC2058-14 & Chlorochroa rossiana \\
\hline UAMIC2058-14 & Chlorochroa rossiana \\
\hline UAMIC2058-14 & Chlorochroa rossiana \\
\hline UAMIC981-13 & Chrysops dawsoni \\
\hline UAMIC957-13 & Chrysops furcatus \\
\hline UAMIC018-12 & Cicindela oregona \\
\hline UAMIC464-13 & Clepsis persicana \\
\hline UAMIC1604-13 & Clubiona canadensis \\
\hline UAMIC1573-13 & Clubiona kulczynskii \\
\hline UAMIC3008-15 & Cnodacophora nasoni \\
\hline UAMIC2955-15 & Cnodacophora nasoni \\
\hline UAMIC2955-15 & Cnodacophora nasoni \\
\hline UAMIC336-13 & Coccinella transversoguttata \\
\hline UAMIC208-13 & Coccinella trifasciata \\
\hline UAMIC771-13 & Coenagrion angulatum \\
\hline UAMIC3292-15 & Coenonympha tullia \\
\hline UAMIC386-13 & Colias gigantea \\
\hline UAMIC3211-15 & Colias kluanensis \\
\hline UAMIC385-13 & Colias philodice \\
\hline UAMIC1701-13 & Coreorgonal monoceros \\
\hline UAMIC3344-15 & Corticaria impressa \\
\hline UAMIC718-13 & Crabro latipes \\
\hline UAMIC3174-15 & Crambus pascuella \\
\hline UAMIC1936-14 & Craspedolepta alaskensis \\
\hline UAMIC636-13 & Ctenicera angusticollis \\
\hline UAMIC1811-14 & Cucujus clavipes \\
\hline UAMIC1921-14 & Cuerna striata \\
\hline UAMIC1552-13 & Cybaeopsis wabritaska \\
\hline UAMIC1564-13 & Cybaeus reticulatus \\
\hline UAMIC030-12 & Cychrus tuberculatus \\
\hline UAMIC3074-15 & Cyclophora pendulinaria \\
\hline UAMIC1489-13 & Cyclosa conica \\
\hline UAMIC2163-14 & Cymatia americana \\
\hline UAMIC2178-14 & Cymatia americana \\
\hline UAMIC2178-14 & Cymatia americana \\
\hline UAMIC638-13 & Deinopteroloma subcostatun \\
\hline UAMIC1034-13 & Delia pilifemur \\
\hline UAMIC2695-15 & Devia prospera \\
\hline UAMIC2664-15 & Devia prospera \\
\hline UAMIC2664-15 & Devia prospera \\
\hline UAMIC551-13 & Diarsia dislocata \\
\hline UAMIC553-13 & Diarsia esurialis \\
\hline UAMIC2463-14 & Dicerca tenebrica \\
\hline UAMIC189-13 & Ditylus gracilis \\
\hline UAMIC282-13 & Ditylus quadricollis \\
\hline
\end{tabular}

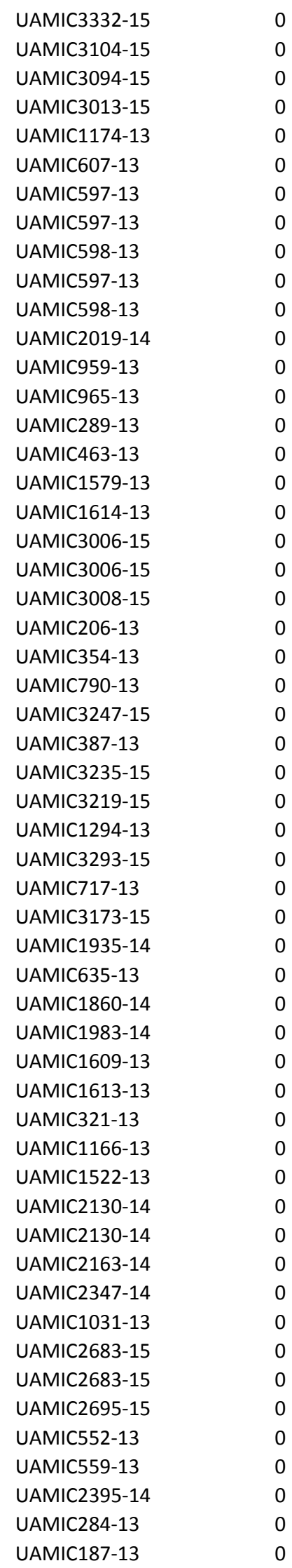


Dolichovespula arenaria

Dolichovespula maculata

Dolichovespula norvegicoides

Dolichovespula norwegica

Dryocoetes autographus

Dysstroma citrata

Dytiscus circumcinctus

Eana osseana

Ecliptopera silaceata

Elaphrus lapponicus

Elasmucha lateralis

Emblethis vicarius

Emblethis vicarius

Emblethis vicarius

Enallagma annexum

Enoplognatha marmorata

Enypia venata

Epinotia solandriana

Epirrita undulata

Epistrophe grossulariae

Erebia disa

Erebia rossii

Eremobina claudens

Eremocoris borealis

Eriocampa ovata

Eriozona laxus

Euchloe ausonides

Eucnecosum tenue

Eudonia spenceri

Eulithis xylina

Eurois astricta

Europiella decolor

Europiella decolor

Europiella decolor

Eustroma semiatrata

Eutrichota tarsata

Euxoa campestris

Formica aserva

Gazoryctra confusus

Gazoryctra confusus

Gazoryctra confusus

Gazoryctra mathewi

Geocoris discopterus

Gerris buenoi

Gerris buenoi

Gerris buenoi

Gerris incognitus

Gerris pingreensis

Gerris pingreensis

Gerris pingreensis

Gluphisia severa

Gnaphosa microps

Gnathacmaeops pratensis

Gonioctena notmani

\begin{tabular}{|c|c|}
\hline UAMIC675-13 & Dolichovespula arenaria \\
\hline UAMIC725-13 & Dolichovespula maculata \\
\hline UAMIC669-13 & Dolichovespula norvegicoides \\
\hline UAMIC667-13 & Dolichovespula norwegica \\
\hline UAMIC2266-14 & Dryocoetes autographus \\
\hline UAMIC535-13 & Dysstroma citrata \\
\hline UAMIC096-13 & Dytiscus circumcinctus \\
\hline UAMIC3185-15 & Eana osseana \\
\hline UAMIC540-13 & Ecliptopera silaceata \\
\hline UAMIC002-12 & Elaphrus lapponicus \\
\hline UAMIC572-13 & Elasmucha lateralis \\
\hline UAMIC1911-14 & Emblethis vicarius \\
\hline UAMIC1930-14 & Emblethis vicarius \\
\hline UAMIC1930-14 & Emblethis vicarius \\
\hline UAMIC813-13 & Enallagma annexum \\
\hline UAMIC1226-13 & Enoplognatha marmorata \\
\hline UAMIC647-13 & Enypia venata \\
\hline UAMIC3160-15 & Epinotia solandriana \\
\hline UAMIC615-13 & Epirrita undulata \\
\hline UAMIC2978-15 & Epistrophe grossulariae \\
\hline UAMIC500-13 & Erebia disa \\
\hline UAMIC492-13 & Erebia rossii \\
\hline UAMIC3111-15 & Eremobina claudens \\
\hline UAMIC1969-14 & Eremocoris borealis \\
\hline UAMIC826-13 & Eriocampa ovata \\
\hline UAMIC2993-15 & Eriozona laxus \\
\hline UAMIC3259-15 & Euchloe ausonides \\
\hline UAMIC1849-14 & Eucnecosum tenue \\
\hline UAMIC3088-15 & Eudonia spenceri \\
\hline UAMIC545-13 & Eulithis xylina \\
\hline UAMIC563-13 & Eurois astricta \\
\hline UAMIC2123-14 & Europiella decolor \\
\hline UAMIC2142-14 & Europiella decolor \\
\hline UAMIC2142-14 & Europiella decolor \\
\hline UAMIC3067-15 & Eustroma semiatrata \\
\hline UAMIC3021-15 & Eutrichota tarsata \\
\hline UAMIC518-13 & Euxoa campestris \\
\hline UAMIC694-13 & Formica aserva \\
\hline UAMIC3355-15 & Gazoryctra confusus \\
\hline UAMIC3354-15 & Gazoryctra confusus \\
\hline UAMIC3354-15 & Gazoryctra confusus \\
\hline UAMIC3272-15 & Gazoryctra mathewi \\
\hline UAMIC1928-14 & Geocoris discopterus \\
\hline UAMIC2183-14 & Gerris buenoi \\
\hline UAMIC2096-14 & Gerris buenoi \\
\hline UAMIC2096-14 & Gerris buenoi \\
\hline UAMIC2120-14 & Gerris incognitus \\
\hline UAMIC2103-14 & Gerris pingreensis \\
\hline UAMIC2158-14 & Gerris pingreensis \\
\hline UAMIC2158-14 & Gerris pingreensis \\
\hline UAMIC3133-15 & Gluphisia severa \\
\hline UAMIC1596-13 & Gnaphosa microps \\
\hline UAMIC2433-14 & Gnathacmaeops pratensis \\
\hline UAMIC2262-14 & Gonioctena notmani \\
\hline
\end{tabular}

UAMIC676-13

UAMIC726-13 0

UAMIC671-13 0

UAMIC670-13

UAMIC182-13

UAMIC534-13 0

UAMIC334-13 0

UAMIC3178-15 0

UAMIC541-13 0

UAMIC306-13 0

UAMIC2088-14 0

UAMIC1973-14 0

UAMIC1973-14 0

UAMIC1911-14 0

UAMIC809-13 0

UAMIC1201-13 0

UAMIC646-13 0

UAMIC466-13 0

UAMIC614-13 0

UAMIC2966-15 0

UAMIC495-13 0

UAMIC493-13 0

UAMIC3061-15 0

UAMIC1908-14 0

UAMIC825-13 0

UAMIC3004-15 0

UAMIC3225-15 0

UAMIC1865-14 0

UAMIC3053-15 0

UAMIC544-13 0

UAMIC564-13 0

UAMIC2107-14 0

UAMIC2107-14 0

UAMIC2123-14 0

UAMIC3073-15 0

UAMIC2986-15 0

UAMIC519-13 0

UAMIC695-13 0

UAMIC663-13 0

UAMIC663-13 0

UAMIC3355-15 0

UAMIC3271-15 0

UAMIC1948-14 0

UAMIC2153-14 0

UAMIC2153-14 0

UAMIC2183-14 0

UAMIC2119-14 0

UAMIC2156-14 0

UAMIC2156-14 0

UAMIC2103-14 0

UAMIC3134-15 0

UAMIC1611-13 0

UAMIC2403-14 0

UAMIC2210-14 0 
Grammoptera subargentata Grammoptera subargentata Grammoptera subargentata Graphiphora augur Gymnusa pseudovariegata Habrosyne scripta Halobisium occidentale Harpalus laticeps Harpalus laticeps Harpalus laticeps Helina cinerella Hesperonemastoma modestum Heterarthrus nemoratus Hilaira herniosa Hippodamia arctica Hippodamia convergens Hippodamia quinquesignata Hippodamia quinquesignata Hippodamia quinquesignata Hippodamia tredecimpunctata Homoeosoma phaeoboreas Hoppingiana hudsonica Hybomitra epistates Hybomitra lurida Hybomitra sexfasciata Hydrellia tenebricosa Hyles gallii Hypnoidus bicolor Hypnoidus rivularius Hypsosinga albovittata Ivielum sibiricum Javesella pellucida Kleidocerys resedae Kleidocerys resedae Kleidocerys resedae Labops burmeisteri Labops burmeisteri Labops burmeisteri Lacanobia radix Laemobothrion vulturis Larinioides patagiatus Lasionycta perplexa Lasius alienus Lasius pallitarsis Leistus ferruginosus Leptothorax canadensis Leucania dia Leucania dia Leucania dia Leucorrhinia glacialis Liogluta nitens Liogluta trapezicollis Liotrichus sagitticollis Litholomia napaea
UAMIC2439-14

UAMIC2443-14

UAMIC2443-14

UAMIC516-13

UAMIC2713-15

UAMIC3371-15

UAMIC1769-14

UAMIC390-13

UAMIC050-12

UAMIC050-12

UAMIC2995-15

UAMIC1780-14

UAMIC807-13

UAMIC1312-13

UAMIC428-13

UAMIC2468-14

UAMIC2380-14

UAMIC2412-14

UAMIC2412-14

UAMIC356-13

UAMIC3130-15

UAMIC3380-15

UAMIC962-13

UAMIC977-13

UAMIC963-13

UAMIC1042-13

UAMIC483-13

UAMIC423-13

UAMIC109-13

UAMIC1476-13

UAMIC1370-13

UAMIC580-13

UAMIC1912-14

UAMIC1940-14

UAMIC1940-14

UAMIC2089-14

UAMIC2057-14

UAMIC2057-14

UAMIC3129-15

UAMIC933-13

UAMIC1428-13

UAMIC3187-15

UAMIC682-13

UAMIC685-13

UAMIC339-13

UAMIC709-13

UAMIC3135-15

UAMIC522-13

UAMIC522-13

UAMIC795-13

UAMIC2665-15

UAMIC2696-15

UAMIC630-13

UAMIC3069-15
Grammoptera subargentata

Grammoptera subargentata

Grammoptera subargentata

Graphiphora augur

Gymnusa pseudovariegata

Habrosyne scripta

Halobisium occidentale

Harpalus laticeps

Harpalus laticeps

Harpalus laticeps

Helina cinerella

UAMIC2394-14

UAMIC2394-14

UAMIC2439-14

UAMIC517-13

UAMIC2741-15

UAMIC3373-15

UAMIC1763-14

UAMIC2864-15

UAMIC2864-15

UAMIC390-13

UAMIC2953-15

Hesperonemastoma modestum UAMIC1807-14

Heterarthrus nemoratus

UAMIC808-13

Hilaira herniosa

Hippodamia arctica

UAMIC1313-13

UAMIC223-13

Hippodamia convergens

Hippodamia quinquesignata

Hippodamia quinquesignata

Hippodamia quinquesignata

Hippodamia tredecimpunctata

Homoeosoma phaeoboreas

Hoppingiana hudsonica

Hybomitra epistates

Hybomitra lurida

Hybomitra sexfasciata

Hydrellia tenebricosa

Hyles gallii

Hypnoidus bicolor

Hypnoidus rivularius

Hypsosinga albovittata

Ivielum sibiricum

Javesella pellucida

Kleidocerys resedae

Kleidocerys resedae

Kleidocerys resedae

Labops burmeisteri

Labops burmeisteri

Labops burmeisteri

Lacanobia radix

Laemobothrion vulturis

Larinioides patagiatus

Lasionycta perplexa

Lasius alienus

Lasius pallitarsis

Leistus ferruginosus

Leptothorax canadensis

Leucania dia

Leucania dia

Leucania dia

Leucorrhinia glacialis

Liogluta nitens

Liogluta trapezicollis

Liotrichus sagitticollis

Litholomia napaea
UAMIC2452-14

UAMIC2440-14

UAMIC2440-14

UAMIC2380-14

UAMIC197-13

UAMIC3131-15

UAMIC3369-15

UAMIC961-13

UAMIC969-13

UAMIC964-13

UAMIC1044-13

UAMIC502-13

UAMIC119-13

UAMIC413-13

UAMIC1466-13

UAMIC1352-13

UAMIC1975-14

UAMIC1979-14

UAMIC1979-14

UAMIC1912-14

UAMIC2084-14

UAMIC2089-14

UAMIC3127-15

UAMIC932-13

UAMIC1457-13

UAMIC3191-15

UAMIC681-13

UAMIC684-13

UAMIC024-12

UAMIC708-13

UAMIC3126-15

UAMIC3126-15

UAMIC3135-15

UAMIC794-13

UAMIC2701-15

UAMIC2740-15

UAMIC629-13

UAMIC3167-15
UAMIC2084-14
0

0

0

0

0

0

0

0

0

0

0

0

0

0

0

0

0

0

0

0

0

0

0

0

0

0

0

0

0

0

0

0

0

0

0

0

0

0

0

0

0

0

0

0

0

0

0

0

0

0

0

0

0

0 
Lithophane pexata

Litomiris debilis

Lonchoptera impicta

Lygus punctatus

Melanophila acuminata

Melanoplus frigidus

Melanoplus sanguinipes

Meligramma triangulifera

Micaria rossica

Microlinyphia pusilla

Myrmica alaskensis

Myrmica incompleta

Nabicula flavomarginata

Nabis americoferus

Nabis inscriptus

Nebria acuta

Nebria gebleri

Nebria lituyae

Nebria mannerheimii

Necrophilus hydrophiloides

Necrophilus hydrophiloides

Necrophilus hydrophiloides

Nehalennia irene

Nemocestes incomptus

Neoleria prominens

Neolygus communis

Neothetalia nimia

Neothetalia pallitarsis

Neothetalia pallitarsis

Neothetalia pallitarsis

Neothetalia pallitarsis

Neothetalia pallitarsis

Neothetalia pallitarsis

Neothetalia pallitarsis

Neothetalia pallitarsis

Neothetalia pallitarsis

Neothetalia pallitarsis

Neottiglossa undata

Neriene radiata

Nicrophorus vespilloides

Nicrophorus vespilloides

Nicrophorus vespilloides

Nicrophorus vespilloides

Nicrophorus vespilloides

Nicrophorus vespilloides

Noctua pronuba

Notaris aethiops

Notiophilus borealis

Notiophilus borealis

Notiophilus borealis

Notonecta kirbyi

Ochlerotatus communis

Ochlerotatus diantaeus

Ochlerotatus punctor

\begin{tabular}{|c|c|}
\hline AMIC3059-15 & Lithophane pexata \\
\hline UAMIC2017-14 & Litomiris debilis \\
\hline UAMIC3029-15 & Lonchoptera impicta \\
\hline UAMIC2022-14 & Lygus punctatus \\
\hline UAMIC392-13 & Melanophila acuminata \\
\hline UAMIC603-13 & Melanoplus frigidus \\
\hline UAMIC605-13 & Melanoplus sanguinipes \\
\hline UAMIC3041-15 & Meligramma triangulifera \\
\hline UAMIC1537-13 & Micaria rossica \\
\hline UAMIC1410-13 & Microlinyphia pusilla \\
\hline UAMIC702-13 & Myrmica alaskensis \\
\hline UAMIC707-13 & Myrmica incompleta \\
\hline UAMIC1998-14 & Nabicula flavomarginata \\
\hline UAMIC2075-14 & Nabis americoferus \\
\hline UAMIC2020-14 & Nabis inscriptus \\
\hline UAMIC345-13 & Nebria acuta \\
\hline UAMIC348-13 & Nebria gebleri \\
\hline UAMIC344-13 & Nebria lituyae \\
\hline UAMIC347-13 & Nebria mannerheimii \\
\hline UAMIC1863-14 & Necrophilus hydrophiloides \\
\hline UAMIC1864-14 & Necrophilus hydrophiloides \\
\hline UAMIC1864-14 & Necrophilus hydrophiloides \\
\hline UAMIC768-13 & Nehalennia irene \\
\hline UAMIC3359-15 & Nemocestes incomptus \\
\hline UAMIC991-13 & Neoleria prominens \\
\hline UAMIC2054-14 & Neolygus communis \\
\hline UAMIC2842-15 & Neothetalia nimia \\
\hline UAMIC2771-15 & Neothetalia pallitarsis \\
\hline UAMIC2759-15 & Neothetalia pallitarsis \\
\hline UAMIC2759-15 & Neothetalia pallitarsis \\
\hline UAMIC2789-15 & Neothetalia pallitarsis \\
\hline UAMIC2789-15 & Neothetalia pallitarsis \\
\hline UAMIC2789-15 & Neothetalia pallitarsis \\
\hline UAMIC2803-15 & Neothetalia pallitarsis \\
\hline UAMIC2803-15 & Neothetalia pallitarsis \\
\hline UAMIC2803-15 & Neothetalia pallitarsis \\
\hline UAMIC2803-15 & Neothetalia pallitarsis \\
\hline UAMIC2086-14 & Neottiglossa undata \\
\hline UAMIC1347-13 & Neriene radiata \\
\hline UAMIC314-13 & Nicrophorus vespilloides \\
\hline UAMIC1835-14 & Nicrophorus vespilloides \\
\hline UAMIC1835-14 & Nicrophorus vespilloides \\
\hline UAMIC2308-14 & Nicrophorus vespilloides \\
\hline UAMIC2308-14 & Nicrophorus vespilloides \\
\hline UAMIC2308-14 & Nicrophorus vespilloides \\
\hline UAMIC649-13 & Noctua pronuba \\
\hline UAMIC143-13 & Notaris aethiops \\
\hline UAMIC1836-14 & Notiophilus borealis \\
\hline UAMIC1897-14 & Notiophilus borealis \\
\hline UAMIC1897-14 & Notiophilus borealis \\
\hline UAMIC642-13 & Notonecta kirbyi \\
\hline UAMIC869-13 & Ochlerotatus communis \\
\hline UAMIC910-13 & Ochlerotatus diantaeus \\
\hline UAMIC866-13 & Ochlerotatus punctor \\
\hline
\end{tabular}

UAMIC3097-15

UAMIC2071-14 0

UAMIC2973-15 0

UAMIC2045-14

UAMIC264-13 0

UAMIC604-13 0

UAMIC606-13 0

UAMIC3042-15 0

UAMIC1581-13 0

UAMIC1394-13 0

UAMIC701-13 0

UAMIC706-13 0

UAMIC1999-14 0

UAMIC2039-14

UAMIC2013-14 0

UAMIC341-13 0

UAMIC350-13 0

UAMIC343-13 0

UAMIC346-13 0

UAMIC1814-14 0

UAMIC1814-14 0

UAMIC1863-14 0

UAMIC770-13 0

UAMIC3362-15 0

UAMIC990-13 0

UAMIC2035-14 0

UAMIC2830-15 0

UAMIC2779-15 0

UAMIC2779-15 0

UAMIC2771-15 0

UAMIC2779-15 0

UAMIC2771-15 0

UAMIC2759-15 0

UAMIC2779-15 0

UAMIC2771-15 0

UAMIC2759-15 0

UAMIC2789-15 0

UAMIC2065-14 0

UAMIC1392-13 0

UAMIC2319-14 0

UAMIC2319-14 0

UAMIC314-13 0

UAMIC2319-14 0

UAMIC314-13 0

UAMIC1835-14 0

UAMIC648-13 0

UAMIC453-13 0

UAMIC1887-14 0

UAMIC1887-14 0

UAMIC1836-14 0

UAMIC641-13 0

UAMIC909-13 0

UAMIC911-13 0

UAMIC867-13 0 
Ochthephilus sp.

Oedothorax alascensis

Oedothorax alascensis

Oedothorax alascensis

Oeneis jutta

Oeneis melissa

Olethreutes costimaculana

Orgyia antiqua

Orthotaenia undulana

Oxidus gracilis

Oxypoda irrasa

Ozyptila arctica

Ozyptila arctica

Ozyptila arctica

Paranonychus brunneus

Parastichtis suspecta

Pardosa groenlandica

Parnassius eversmanni

Parnassius phoebus

Patrobus cinctus

Pelecomalium testaceum

Pelecomalium testaceum

Pelecomalium testaceum

Pellenes lapponicus

Peritrechus convivus

Peritrechus convivus

Peritrechus convivus

Perizoma grandis

Phalangium opilio

Phalangium opilio

Phellopsis porcata

Pherbellia nana

Philaenarcys bilineata

Philhygra jarmilae

Philodromus cespitum

Philonthus boreas

Philonthus politus

Phlaeopterus fusconiger

Phlaeopterus houkae

Phlaeopterus houkae

Phlaeopterus houkae

Phlaeopterus houkae

Phloeostiba lapponica

Pholcus phalangioides

Phratora interstitialis

Pieris marginalis

Pieris marginalis

Pieris marginalis

Pieris marginalis

Pieris marginalis

Pieris marginalis

Pinalitus approximatus

Pirata bryantae

Piratula canadensis
UAMIC2929-15

UAMIC1319-13 Oedothorax alascensis

UAMIC1319-13 Oedothorax alascensis

UAMIC3223-15

UAMIC3254-15

UAMIC3181-15

UAMIC3276-15

UAMIC470-13

UAMIC935-13

UAMIC2809-15

UAMIC1767-14

UAMIC1749-14

UAMIC1749-14

UAMIC1779-14

UAMIC3156-15

UAMIC1510-13

UAMIC3212-15

UAMIC439-13

UAMIC299-13

UAMIC2321-14

UAMIC2344-14

UAMIC2344-14

UAMIC1771-14

UAMIC2026-14

UAMIC2056-14

UAMIC2056-14

UAMIC506-13

UAMIC1804-14

UAMIC1803-14

UAMIC190-13

UAMIC3307-15

UAMIC1939-14

UAMIC2806-15

UAMIC1654-13

UAMIC122-13

UAMIC2910-15

UAMIC1121-13

UAMIC2369-14

UAMIC2293-14

UAMIC2293-14

UAMIC2293-14

UAMIC2323-14

UAMIC1300-13

UAMIC449-13

UAMIC481-13

UAMIC489-13

UAMIC489-13

UAMIC444-13

UAMIC444-13

UAMIC444-13

UAMIC2050-14

UAMIC1437-13

UAMIC1508-13
Oeneis jutta

Oeneis melissa

Olethreutes costimaculana

Orgyia antiqua

Orthotaenia undulana

Oxidus gracilis

Oxypoda irrasa

Ozyptila arctica

Ozyptila arctica

Ozyptila arctica

Paranonychus brunneus

Parastichtis suspecta

Pardosa groenlandica

Parnassius eversmanni

Parnassius phoebus

Patrobus cinctus

Pelecomalium testaceum

Pelecomalium testaceum

Pelecomalium testaceum

Pellenes lapponicus

Peritrechus convivus

Peritrechus convivus

Peritrechus convivus

Perizoma grandis

Phalangium opilio

Phalangium opilio

Phellopsis porcata

Pherbellia nana

Philaenarcys bilineata

Philhygra jarmilae

Philodromus cespitum

Philonthus boreas

Philonthus politus

Phlaeopterus fusconiger

Phlaeopterus houkae

Phlaeopterus houkae

Phlaeopterus houkae

Phlaeopterus houkae

Phloeostiba lapponica

Pholcus phalangioides

Phratora interstitialis

Pieris marginalis

Pieris marginalis

Pieris marginalis

Pieris marginalis

Pieris marginalis

Pieris marginalis

Pinalitus approximatus

Pirata bryantae

Piratula canadensis
UAMIC2858-15 0

UAMIC1712-13 0

UAMIC1712-13 0

UAMIC1631-13 0

UAMIC480-13 0

UAMIC3201-15 0

UAMIC3184-15 0

UAMIC3277-15 0

UAMIC469-13 0

UAMIC934-13 0

UAMIC2774-15 0

UAMIC1686-13 0

UAMIC1686-13 0

UAMIC1767-14 0

UAMIC1732-14 0

UAMIC3063-15 0

UAMIC1463-13 0

UAMIC3239-15 0

UAMIC438-13 0

UAMIC093-12 0

UAMIC2357-14 0

UAMIC2357-14 0

UAMIC2321-14 0

UAMIC1762-14 0

UAMIC2018-14 0

UAMIC2018-14 0

UAMIC2026-14 0

UAMIC505-13 0

UAMIC1738-14 0

UAMIC1797-14 0

UAMIC1856-14 0

UAMIC3305-15 0

UAMIC1932-14 0

UAMIC2772-15 0

UAMIC1565-13 0

UAMIC2863-15 0

UAMIC125-13 0

UAMIC1120-13 0

UAMIC2310-14 0

UAMIC2310-14 0

UAMIC2373-14 0

UAMIC2369-14 0

UAMIC2334-14 0

UAMIC1264-13 0

UAMIC244-13 0

UAMIC445-13 0

UAMIC445-13 0

UAMIC481-13 0

UAMIC445-13 0

UAMIC481-13 0

UAMIC489-13 0

UAMIC2049-14 0

UAMIC1589-13 0

UAMIC1616-13 0 
Placusa tacomae

Placusa tacomae

Placusa tacomae

Plebejus idas

Plutella xylostella

Polia purpurissata

Polia richardsoni

Porrhomma boreale

Prepops nigripilus

Protocalliphora bennetti

Protocalliphora tundrae

Protolampra rufipectus

Pterostichus agonus

Pterostichus agonus

Pterostichus agonus

Pterostichus algidus

Pterostichus castaneus

Pterostichus crenicollis

Pterostichus empetricola

Pterostichus sublaevis

Quedius fulvicollis

Reesa vespulae

Rhaphium crassipes

Rhaphium terminale

Rhinosimus viridiaeneus

Robertus arcticus

Robertus crosbyi

Robertus fuscus

Rugathodes aurantius

Saldula nigrita

Saldula saltatoria

Saldula saltatoria

Saldula saltatoria

Sciastes truncatus

Scopula frigidaria

Simplocaria metallica

Sitticus finschi

Smerinthus cerisyi

Somatochlora hudsonica

Sonoma margemina

Spargania magnoliata

Speranza boreata

Stenodema trispinosa

Steremnius tuberosus

Sunira verberata

Sunira verberata

Sunira verberata

Sympetrum internum

Syneta carinata

Syneta carinata

Syneta carinata

Syngrapha alias

Syngrapha interrogationis

Syrphus ribesii

\begin{tabular}{|c|c|}
\hline UAMIC2816-15 & Placusa tacomae \\
\hline UAMIC2795-15 & Placusa tacomae \\
\hline UAMIC2795-15 & Placusa tacomae \\
\hline UAMIC3245-15 & Plebejus idas \\
\hline UAMIC3303-15 & Plutella xylostella \\
\hline UAMIC3182-15 & Polia purpurissata \\
\hline UAMIC3169-15 & Polia richardsoni \\
\hline UAMIC1693-13 & Porrhomma boreale \\
\hline UAMIC2001-14 & Prepops nigripilus \\
\hline UAMIC2985-15 & Protocalliphora bennetti \\
\hline UAMIC890-13 & Protocalliphora tundrae \\
\hline UAMIC3102-15 & Protolampra rufipectus \\
\hline UAMIC1877-14 & Pterostichus agonus \\
\hline UAMIC1854-14 & Pterostichus agonus \\
\hline UAMIC1854-14 & Pterostichus agonus \\
\hline UAMIC086-12 & Pterostichus algidus \\
\hline UAMIC088-12 & Pterostichus castaneus \\
\hline UAMIC028-12 & Pterostichus crenicollis \\
\hline UAMIC091-12 & Pterostichus empetricola \\
\hline UAMIC082-12 & Pterostichus sublaevis \\
\hline UAMIC104-13 & Quedius fulvicollis \\
\hline UAMIC098-13 & Reesa vespulae \\
\hline UAMIC882-13 & Rhaphium crassipes \\
\hline UAMIC884-13 & Rhaphium terminale \\
\hline UAMIC150-13 & Rhinosimus viridiaeneus \\
\hline UAMIC1225-13 & Robertus arcticus \\
\hline UAMIC1233-13 & Robertus crosbyi \\
\hline UAMIC1784-14 & Robertus fuscus \\
\hline UAMIC1202-13 & Rugathodes aurantius \\
\hline UAMIC2124-14 & Saldula nigrita \\
\hline UAMIC2099-14 & Saldula saltatoria \\
\hline UAMIC2093-14 & Saldula saltatoria \\
\hline UAMIC2093-14 & Saldula saltatoria \\
\hline UAMIC1366-13 & Sciastes truncatus \\
\hline UAMIC508-13 & Scopula frigidaria \\
\hline UAMIC1876-14 & Simplocaria metallica \\
\hline UAMIC1757-14 & Sitticus finschi \\
\hline UAMIC3119-15 & Smerinthus cerisyi \\
\hline UAMIC822-13 & Somatochlora hudsonica \\
\hline UAMIC1103-13 & Sonoma margemina \\
\hline UAMIC3085-15 & Spargania magnoliata \\
\hline UAMIC3106-15 & Speranza boreata \\
\hline UAMIC2051-14 & Stenodema trispinosa \\
\hline UAMIC377-13 & Steremnius tuberosus \\
\hline UAMIC1161-13 & Sunira verberata \\
\hline UAMIC520-13 & Sunira verberata \\
\hline UAMIC520-13 & Sunira verberata \\
\hline UAMIC802-13 & Sympetrum internum \\
\hline UAMIC2255-14 & Syneta carinata \\
\hline UAMIC2202-14 & Syneta carinata \\
\hline UAMIC2202-14 & Syneta carinata \\
\hline UAMIC3082-15 & Syngrapha alias \\
\hline UAMIC3140-15 & Syngrapha interroga \\
\hline UAMIC3005-15 & Syrphus ribesii \\
\hline
\end{tabular}

UAMIC2796-15

UAMIC2796-15 0

UAMIC2816-15 0

UAMIC3222-15

UAMIC3304-15 0

UAMIC3175-15 0

UAMIC3168-15 0

UAMIC1415-13 0

UAMIC2076-14 0

UAMIC2974-15 0

UAMIC889-13 0

UAMIC3064-15 0

UAMIC1900-14 0

UAMIC1900-14

UAMIC1877-14 0

UAMIC297-13 0

UAMIC296-13 0

UAMIC361-13 0

UAMIC1839-14 0

UAMIC295-13 0

UAMIC2903-15 0

UAMIC448-13 0

UAMIC888-13 0

UAMIC886-13 0

UAMIC1867-14 0

UAMIC1227-13 0

UAMIC1759-14 0

UAMIC1218-13 0

UAMIC1230-13 0

UAMIC2136-14 0

UAMIC2155-14 0

UAMIC2155-14 0

UAMIC2099-14 0

UAMIC1709-13 0

UAMIC509-13 0

UAMIC1855-14 0

UAMIC1754-14 0

UAMIC3132-15 0

UAMIC824-13 0

UAMIC1104-13 0

UAMIC507-13 0

UAMIC3107-15 0

UAMIC2078-14 0

UAMIC178-13 0

UAMIC521-13 0

UAMIC521-13 0

UAMIC1161-13 0

UAMIC801-13 0

UAMIC2226-14 0

UAMIC2226-14 0

UAMIC2255-14 0

UAMIC3098-15 0

UAMIC3141-15 0

UAMIC2961-15 0 


\author{
Tanyrhinus singularis \\ Tarphiota fucicola \\ Tarphiota fucicola \\ Tarphiota fucicola \\ Tegenaria domestica \\ Teloleuca bifasciata \\ Teratocoris saundersi \\ Tethina thula \\ Thanatus formicinus \\ Thelaira bryanti \\ Tibellus asiaticus \\ Tibellus oblongus \\ Tibioplus diversus \\ Tipula appendiculata \\ Tipula bergrothiana \\ Tipula entomophthorae \\ Trechus chalybeus \\ Trichadenotecnum majus \\ Trichophya pilicornis \\ Trochosa terricola \\ Trochosa terricola \\ Trochosa terricola \\ Trypodendron lineatum \\ Trypodendron lineatum \\ Trypophloeus striatulus \\ Urocerus flavicornis \\ Venusia cambrica \\ Vespula alascensis \\ Vespula rufa \\ Walckenaeria atrotibialis \\ Walckenaeria lepida \\ Walckenaeria subspiralis \\ Xestia c-nigrum \\ Xestia oblata \\ Xestia perquiritata \\ Xestia smithii \\ Xestia tecta \\ Xylophagus fulgidus \\ Xylophagus fulgidus \\ Xylophagus fulgidus \\ Xysticus emertoni \\ Zelotes puritanus
}

\begin{tabular}{|c|c|}
\hline UAMIC327-13 & Tanyrhinus singularis \\
\hline UAMIC2844-15 & Tarphiota fucicola \\
\hline UAMIC2783-15 & Tarphiota fucicola \\
\hline UAMIC2783-15 & Tarphiota fucicola \\
\hline UAMIC1577-13 & Tegenaria domestica \\
\hline UAMIC2148-14 & Teloleuca bifasciata \\
\hline UAMIC2085-14 & Teratocoris saundersi \\
\hline UAMIC926-13 & Tethina thula \\
\hline UAMIC1663-13 & Thanatus formicinus \\
\hline UAMIC1024-13 & Thelaira bryanti \\
\hline UAMIC1664-13 & Tibellus asiaticus \\
\hline UAMIC1694-13 & Tibellus oblongus \\
\hline UAMIC1675-13 & Tibioplus diversus \\
\hline UAMIC1097-13 & Tipula appendiculata \\
\hline UAMIC1060-13 & Tipula bergrothiana \\
\hline UAMIC1017-13 & Tipula entomophthorae \\
\hline UAMIC037-12 & Trechus chalybeus \\
\hline UAMIC3386-15 & Trichadenotecnum majus \\
\hline UAMIC2827-15 & Trichophya pilicornis \\
\hline UAMIC1601-13 & Trochosa terricola \\
\hline UAMIC1484-13 & Trochosa terricola \\
\hline UAMIC1484-13 & Trochosa terricola \\
\hline UAMIC2198-14 & Trypodendron lineatum \\
\hline UAMIC252-13 & Trypodendron lineatum \\
\hline UAMIC2251-14 & Trypophloeus striatulus \\
\hline UAMIC777-13 & Urocerus flavicornis \\
\hline UAMIC3048-15 & Venusia cambrica \\
\hline UAMIC714-13 & Vespula alascensis \\
\hline UAMIC672-13 & Vespula rufa \\
\hline UAMIC1356-13 & Walckenaeria atrotibialis \\
\hline UAMIC1409-13 & Walckenaeria lepida \\
\hline UAMIC1388-13 & Walckenaeria subspiralis \\
\hline UAMIC529-13 & Xestia c-nigrum \\
\hline UAMIC3047-15 & Xestia oblata \\
\hline UAMIC524-13 & Xestia perquiritata \\
\hline UAMIC527-13 & Xestia smithii \\
\hline UAMIC3163-15 & Xestia tecta \\
\hline UAMIC3009-15 & Xylophagus fulgidus \\
\hline UAMIC3010-15 & Xylophagus fulgidus \\
\hline UAMIC3010-15 & Xylophagus fulgidus \\
\hline UAMIC1774-14 & Xysticus emertoni \\
\hline UAMIC1608-13 & Zelotes puritanus \\
\hline
\end{tabular}

UAMIC188-13 0

UAMIC2782-15 0

UAMIC2782-15 0

UAMIC2844-15 0

UAMIC1610-13 0

UAMIC2111-14 0

UAMIC2082-14 0

UAMIC925-13 0

UAMIC1702-13 0

UAMIC1023-13 0

UAMIC1621-13 0

UAMIC1665-13 0

UAMIC1414-13 0

UAMIC1099-13 0

UAMIC1059-13 0

UAMIC1016-13 0

UAMIC473-13 0

UAMIC3385-15 0

UAMIC2330-14 0

UAMIC1550-13 0

UAMIC1550-13 0

UAMIC1601-13 0

UAMIC2240-14 0

UAMIC2237-14 0

UAMIC2224-14 0

UAMIC829-13 0

UAMIC3076-15 0

UAMIC674-13 0

UAMIC705-13 0

UAMIC1705-13 0

UAMIC1391-13 0

UAMIC1671-13 0

UAMIC528-13 0

UAMIC3188-15 0

UAMIC525-13 0

UAMIC611-13 0

UAMIC3154-15 0

UAMIC2964-15 0

UAMIC2964-15 0

UAMIC3009-15 0

UAMIC1727-14 0

UAMIC1554-13 0 